Published in final edited form as:

Cochrane Database Syst Rev. ; 4: CD002042. doi:10.1002/14651858.CD002042.pub3.

\title{
Transfusion thresholds and other strategies for guiding allogeneic red blood cell transfusion
}

\author{
Jeffrey L Carson ${ }^{1}$, Paul A Carless ${ }^{2}$, and Paul C Hebert ${ }^{3}$ \\ ${ }^{1}$ Division of General Internal Medicine, UMDNJ-Robert Wood Johnson Medical School, New \\ Brunswick, New Jersey, USA \\ ${ }^{2}$ Discipline of Clinical Pharmacology, Faculty of Health, University of Newcastle, Newcastle, \\ Australia \\ ${ }^{3}$ Department of Medicine, Ottawa General Hospital, Ottawa, Canada
}

\section{Abstract}

\begin{abstract}
Background-Most clinical practice guidelines recommend restrictive red cell transfusion practices, with the goal of minimising exposure to allogeneic blood. The purpose of this review is to compare clinical outcomes in patients randomised to restrictive versus liberal transfusion thresholds (triggers).
\end{abstract}

Objectives-To examine the evidence for the effect of transfusion thresholds on the use of allogeneic and/or autologous red cell transfusion, and the evidence for any effect on clinical outcomes.

\begin{abstract}
Search methods-We identified trials by searching: the Cochrane Injuries Group Specialised Register (searched 1 February 2011), the Cochrane Central Register of Controlled Trials (CENTRAL) (The Cochrane Library 2011, Issue 1), MEDLINE (Ovid) 1948 to January Week 3 2011, EMBASE (Ovid) 1980 to 2011 (Week 04), ISI Web of Science: Science Citation Index Expanded (1970 to February 2011) and ISI Web of Science: Conference Proceedings Citation Index - Science (1990 to February 2011). We checked reference lists of other published reviews and relevant papers to identify any additional trials.
\end{abstract}

\footnotetext{
Copyright () 2012 The Cochrane Collaboration. Published by John Wiley \& Sons, Ltd.

Contact address: Jeffrey L Carson, Division of General Internal Medicine, UMDNJ-Robert Wood Johnson Medical School, 125

Paterson Street, New Brunswick, New Jersey, 08903, USA. carson@umdnj.edu.

Editorial group: Cochrane Injuries Group.

Publication status and date: Edited (no change to conclusions), published in Issue 5, 2012.

Review content assessed as up-to-date: 1 February 2011.

CONTRIBUTIONS OF AUTHORS

Contributors (names are listed alphabetically):

Paul Carless (University of Newcastle) performed original database literature searches, screened abstracts and titles for relevant articles, obtained relevant papers, applied inclusion/exclusion criteria to retrieved papers, extracted data from the trials, quality assessed trials, entered data into Meta-View 4.1, entered all study details into Review Manager 5.1, and co-wrote the review; Jeffrey Carson (Robert Wood Johnson Medical School) for the 2011 update, screened abstracts and titles for relevant articles, obtained relevant papers, applied inclusion/exclusion criteria to retrieved papers, extracted data from the trials, quality assessed trials, entered data into Meta-View 4.1, entered all study details into Review Manager 5.1, and co-wrote review; Paul Hebert (Ottawa General Hospital) reviewed the manuscript, provided expertise with analysis and content expert opinion.

DECLARATIONS OF INTEREST

Dr. Carson reports receiving grant support to his institution from Amgen and US National Institutes of Health. He is involved with guideline development. Dr. Hebert reports receiving grant support from Amgen and Johnson and Johnson.
} 
Selection criteria-Controlled trials in which patients were randomised to an intervention group or to a control group. We included trials where intervention groups were assigned on the basis of a clear transfusion 'trigger', described as a haemoglobin $(\mathrm{Hb})$ or haematocrit (Hct) level below which a red blood cell (RBC) transfusion was to be administered.

Data collection and analysis-We pooled risk ratios of requiring allogeneic blood transfusion, transfused blood volumes and other clinical outcomes across trials using a randomeffects model. Two people performed data extraction and assessment of the risk of bias.

Main results-We included 19 trials involving a total of 6264 patients and they were similar enough that results could be combined. Restrictive transfusion strategies reduced the risk of receiving a RBC transfusion by $39 \%$ (risk ratio (RR) $0.61,95 \%$ confidence interval (CI) 0.52 to 0.72). This equates to an average absolute risk reduction (ARR) of $34 \%$ (95\% CI $24 \%$ to $45 \%$ ). The volume of RBCs transfused was reduced on average by 1.19 units (95\% CI 0.53 to 1.85 units). However, heterogeneity between trials was statistically significant $\left(\mathrm{P}<0.00001 ; \mathrm{I}^{2} \geq 93 \%\right)$ for these outcomes. Restrictive transfusion strategies did not appear to impact the rate of adverse events compared to liberal transfusion strategies (i.e. mortality, cardiac events, myocardial infarction, stroke, pneumonia and thromboembolism). Restrictive transfusion strategies were associated with a statistically significant reduction in hospital mortality (RR $0.77,95 \%$ CI 0.62 to 0.95 ) but not 30-day mortality (RR $0.85,95 \%$ CI 0.70 to 1.03 ). The use of restrictive transfusion strategies did not reduce functional recovery, hospital or intensive care length of stay. The majority of patients randomised were included in good-quality trials, but some items of methodological quality were unclear. There are no trials in patients with acute coronary syndrome.

Authors' conclusions-The existing evidence supports the use of restrictive transfusion triggers in most patients, including those with pre-existing cardiovascular disease. As there are no trials, the effects of restrictive transfusion triggers in high-risk groups, such as acute coronary syndrome, need to be tested in further large clinical trials. In countries with inadequate screening of donor blood, the data may constitute a stronger basis for avoiding transfusion with allogeneic red cells.

\section{Medical Subject Headings (MeSH)}

*Practice Guidelines as Topic; Erythrocyte Transfusion [adverse effects; mortality; *standards]; Hematocrit [standards]; Hemoglobin A [analysis]; Randomized Controlled Trials as Topic; Reference Values; Transplantation, Autologous [standards]; Transplantation, Homologous [mortality; standards]

\section{MeSH check words}

Humans

\section{BACKGROUND}

Blood is an indispensable product in modern medical practice (Amin 2004). Red blood cells (RBC) are used to improve oxygen delivery to tissues in situations of haemorrhage and anaemia (Napolitano 2009). Red blood cell transfusion constitutes one of the mainstays of therapy in the management of anaemic patients and is one of the few treatments that 
adequately restores tissue oxygenation when oxygen demand exceeds supply (Klein 2007; Wang 2010).

The risk and availability of red blood cell transfusion varies throughout the world. In most developed countries with well-regulated blood supplies, the safety of allogeneic red cell transfusion has improved significantly over the past 30 years. This has been primarily due to improvements in donor blood screening procedures and the implementation of more stringent quality control measures (Klein 2007). It has been estimated that the residual risk of transmission through transfusion of HIV, HCV and HBV in Canada is 1 per 7.8 million donations, 1 per 2.3 million donations and 1 per 153,000 donations respectively (O'Brien 2007). Globally, the estimated risks of infection per blood unit range from 1 per 100,000 to 1 per 400,000 for HBV, 1 per 1.6 million to 1 per 3.1 million for $\mathrm{HCV}, 1$ per 1.4 million to 1 per 4.7 million for HIV, and 1 per 500,000 to 1 per 3.0 million for human T cell lymphotropic virus (Goodnough 2008). Data from seven developed countries from 2000 to 2005 showed the residual risk of transfusion-transmitted viral infections ranged from 0.22 to 2.48 per 1 million donations for HIV, 0.05 to 3.94 per 1 million donations for $\mathrm{HCV}$ and 1.51 to 9.78 per 1 million donations for HBV (Kitchen 2008). In the USA, the estimated risk per unit for HIV is 1:1,467,000 (Zou 2010), for HCV is 1:1,149,000 (Zou 2010) and for HBV is $1: 282,000$ to 357,000 (Zou 2009). In the USA, life-threatening reactions were also estimated to occur in 1: 139,908 patients transfused (Whitaker 2011).

In developing countries, the supply of blood is inadequate and may not be safe because it often is not tested for viral pathogens. Blood donations are not routinely tested in 39 countries for transfusion-transmissible infections including HIV, hepatitis $\mathrm{B}$, hepatitis $\mathrm{C}$ and syphilis (WHO 2011). In 40 countries, less than $25 \%$ of the blood supply is collected from voluntary unpaid blood donors, with most coming from family or paid blood donors (WHO 2011). The prevalence of HIV in low-income countries is $2.3 \%$ of blood donations compared to $0.001 \%$ in high-income countries (WHO 2011).

Blood transfusion is expensive. In 2008, the mean payment for one unit of leukoreduced red blood cells in the United States was USD 223 (Whitaker 2011). However, if the costs of administration as well as the acquisition expenses of red blood cell transfusion are considered, the estimated cost derived from four US and European hospitals rises to USD 761 per unit (standard deviation +/- USD 294) (Shander 2010).

\section{Description of the intervention}

Historically, the widely accepted clinical standard was to transfuse patients when the haemoglobin level dropped below $10.0 \mathrm{~g} / \mathrm{dL}$ or the haematocrit fell below $30 \%$. This ' $10 / 30$ rule' was first proposed by Adams and Lundy in 1942 and served as a RBC transfusion trigger for decades (Madjdpour 2005; Wang 2010). However, the 1988 National Institutes of Health Consensus Conference in the United States reported that the evidence did not support a single criterion for transfusion (NIH 1988). Since then, several published guidelines have advised against a single threshold for red cell transfusion, recommending that a range of haemoglobin values between 6.0 and $10.0 \mathrm{~g} / \mathrm{dL}$ can be used, depending on the presence of serious co-morbidity (AAGBI 2008; ASA 2006; ASBT 2001; BCTMAG 2003; Napolitano 2009; NBUGI 2001). 
Clinical trials evaluating transfusion thresholds usually compare two transfusion groups: 1) liberal transfusion where patients receive blood at a higher haemoglobin concentration, and

2) restrictive transfusion where patients receive blood at a lower haemoglobin concentration.

\section{Why it is important to do this review}

The purpose of the review was to find, appraise and summarise the data from high-quality trials that studied the clinical impact of varying thresholds for transfusion with red cells. We were particularly interested in whether the results of randomised controlled trials support the trend for increasingly restrictive red cell transfusion practices and if red cell transfusions can be withheld in some circumstances without harming patients. We have updated the review because two recent trials (Carson 2011; Hajjar 2010) were published, increasing the number of patients included in this review from 3746 to 6264 .

\section{OBJECTIVES}

To examine the evidence for the effect of transfusion thresholds on the use of red cell transfusions and the evidence for any change in clinical outcomes.

\section{METHODS}

\section{Criteria for considering studies for this review}

Types of studies-Randomised controlled trials with a concurrent control group. We included trials if the comparison groups were assigned on the basis of a clear transfusion 'trigger' or 'threshold', described as a haemoglobin or haematocrit level (with or without a specified level of haemodynamic instability) that had to be reached before a red cell transfusion was administered. Control group patients were required to be either transfused with allogeneic and/or autologous red blood cells at higher $\mathrm{Hb}$ or Hct levels (transfusion threshold) than the intervention group or transfused in accordance with current transfusion practices, which may not have included a well-defined transfusion threshold, but involved liberal rather than restrictive transfusion practices.

Types of participants-We included trials of surgical or medical patients, involving adults and/or children. We excluded neonates.

Types of interventions-The intervention considered was the use of transfusion thresholds ('triggers') as a means of guiding allogeneic and/or autologous red blood cell transfusion.

\section{Types of outcome measures}

\section{Primary outcomes}

- The proportion of patients 'at risk' who were transfused with allogeneic and/or autologous red blood cells.

\section{Secondary outcomes}

- The amounts of allogeneic and autologous blood transfused. 
- Morbidity (non-fatal myocardial infarction, cardiac events, pulmonary oedema, cerebral vascular accident, thromboembolism, renal failure, infection, haemorrhage, mental confusion), mortality, haematocrit levels (postoperative/ discharge) and length of hospital stay (LOS). We expected the definitions of each of the morbidity events to vary between studies.

\section{Search methods for identification of studies}

We did not restrict our search for trials by date, language or publication status.

Electronic searches-The Cochrane Injuries Group Trials Search Co-ordinator conducted the latest search for trials and collated the results. We searched the following databases:

- the Cochrane Injuries Group's Specialised Register (searched 1 February 2011);

- the Cochrane Central Register of Controlled Trials (CENTRAL) (The Cochrane Library 2011, Issue 1);

- $\quad$ MEDLINE (Ovid) 1950 to January Week 3 2011;

- $\quad$ EMBASE (Ovid) 1980 to 2011 Week 04;

- ISI Web of Science: Science Citation Index Expanded (SCI-EXPANDED) (1970 to February 2011);

- ISI Web of Science: Conference Proceedings Citation Index - Science (CPCI-S) (1990 to February 2011).

The search strategies are presented in Appendix 1.

Searching other resources-We contacted experts in the field to identify information relevant to the review. Where possible, we contacted authors of published studies for clarification of trial methodology and data. This was only possible where a contact address was reported in the published study. We searched the reference lists of relevant reviews and published papers as well as the reference lists of all included trials for further studies.

\section{Data collection and analysis}

Selection of studies-Two authors (JLC and PAC) independently screened the titles, abstracts, or both, of the search results and selected trials that met the previously defined inclusion criteria. We discussed inclusion of studies until consensus was reached; there were no disagreements on the inclusion of studies. We identified trials in which patients were randomised to a restrictive transfusion strategy (transfusion threshold and/or protocol), or to a control group which was randomised to a liberal transfusion strategy. JLC and PAC independently extracted study characteristics and outcomes using a data extraction form. The extraction form recorded information regarding: study type, methodology descriptions, the presence of a transfusion threshold, transfusion protocol, the type of surgery involved, clinical setting, treatment outcomes and general comments. 
Data extraction and management-JLC and PAC performed data extraction on articles that met the inclusion criteria. JLC then entered data into Review Manager; data were checked by PAC. We contacted authors of trials to request missing data.

We used a data extraction form to record data on the following outcomes: the number of patients exposed to allogeneic blood, the amount of allogeneic blood transfused, the number of patients receiving any transfusion (allogeneic blood, autologous blood, or both). For trials involving surgical patients, we recorded the following outcomes: postoperative complications (infection, haemorrhage, non-fatal myocardial infarction, cardiac events, renal failure, stroke, thromboembolism, pulmonary oedema, mental confusion), mortality and length of hospital stay (LOS). We recorded data for blood loss and haemoglobin and haematocrit levels (on admission, pre-post transfusion and at discharge). We recorded information regarding demographics (age, sex), type of surgery or medical condition on the data extraction form. We extracted data for allogeneic blood transfusion if it was expressed as packed red blood cells (RBC). We documented information regarding the use of fresh frozen plasma (FFP) and/or platelets.

Assessment of risk of bias in included studies-The Cochrane Collaboration's tool for assessing risk of bias is described in section 8.5 of the Cochrane Handbook for Systematic Reviews of Interventions (Higgins 2011).

JLC and PAC assessed the following domains for each study:

- $\quad$ sequence generation;

- allocation concealment;

- blinding;

- incomplete outcome data;

- selective outcome reporting;

- other potential sources of bias.

We completed a 'Risk of bias' table for each study, incorporating a description of the study's performance against each of the above domains and our overall judgement of the risk of bias for each entry as follows: 'Low', 'Unclear' (indicating unclear or unknown risk of bias) and 'High' risk of bias.

Measures of treatment effect-We calculated the risk ratio (RR) for allogeneic blood transfusion in the intervention group as compared with the control group and the corresponding 95\% confidence intervals for each trial using the random-effects model (Der Simonian 1986). We adopted a similar approach to examine the other outcomes of transfusion. We also entered the mean number of units of red blood cells transfused to each group and the corresponding standard deviations. We used the mean difference (MD) and 95\% confidence intervals (CI) to express the average reduction in the number of units of $\mathrm{RBC}$ administered to the intervention group, compared with the control. 
Unit of analysis issues-The unit of analysis was the patient. We converted data expressed in millilitres $(\mathrm{ml})$ for the volume of blood transfused to units of blood by dividing by 300 .

Dealing with missing data-All analyses were on an intention-to-treat basis. We imputed no missing data.

Assessment of heterogeneity-There was significant clinical heterogeneity. The trials included surgical, medical and critical care patients. We pooled the data for all outcomes and presented data stratified by subgroups for the primary outcome only. The subgroups evaluated were allogeneic transfusion, autologous transfusion and clinical settings (cardiac surgery, orthopaedic surgery, vascular surgery, acute blood loss/trauma, cancer and critical care). We also examined the proportion of patients exposed to transfusion stratified by the transfusion threshold (difference $\geq 2 \mathrm{~g} / \mathrm{dL},<2 \mathrm{~g} / \mathrm{dL}$ ), risk of bias and units of blood transfused.

We examined statistical heterogeneity using both the $\mathrm{I}^{2}$ statistic and $\mathrm{Chi}^{2}$ test. The $\mathrm{I}^{2}$ statistic describes the percentage of total variation across studies due to heterogeneity rather than chance. A value of $0 \%$ indicates no observed heterogeneity and larger values show increasing heterogeneity; substantial heterogeneity is considered to exist when the $\mathrm{I}^{2}>50 \%$ (Higgins 2011). For the $\mathrm{Chi}^{2}$ test, we used a $\mathrm{P}$ value of $<0.10$ to indicate the presence of statistically significant heterogeneity.

Assessment of reporting biases-We examined funnel plots for evidence of publication bias. Although the small number of trials hampered funnel plot assessment, the outcome with the largest data set could be assessed for the presence of publication bias. The funnel plot for this outcome is presented in Figure 1.

Data synthesis-Due to the anticipated significant clinical heterogeneity of the trials, we analysed data using a random-effects model.

We performed all analyses using Review Manager software. We entered data on the numbers of patients exposed to allogeneic blood and the numbers of patients in each treatment group into Review Manager. We converted data in millilitres (ml) to units by dividing by 300 . We converted studies reporting haematocrit to haemoglobin concentration by dividing by three.

Subgroup analysis and investigation of heterogeneity-We performed subgroup analyses to explore treatment effects by blood product (allogeneic versus autologous, units of blood transfused), clinical setting (cardiac surgery, orthopaedic surgery, vascular surgery, acute blood loss/trauma, cancer, critical care), transfusion threshold (difference $\geq 2$ grams per decilitre and difference less than 2 grams per decilitre) and risk of bias.

Sensitivity analysis-We performed a sensitivity analysis to assess the effects of study allocation concealment on the results. 


\section{RESULTS \\ Description of studies}

See: Characteristics of included studies; Characteristics of excluded studies; Characteristics of studies awaiting classification; Characteristics of ongoing studies.

Results of the search-The original literature search conducted in 1999 identified 110 full-text articles. Of these 110 eligible studies, 99 were excluded from further assessment (transfusion audits and reviews $\mathrm{n}=94$; observational studies - cohort or case-control studies $\mathrm{n}=5$ ). We considered 11 full-text articles for review. Of these 11 studies one was excluded because the trigger was based on the level of HbS not the haemoglobin or haematocrit level.

We conducted an updated search in November 2004. No new trials were identified by this search.

An updated search conducted in 2009 identified an additional seven trials. A further search conducted in February 2011 identified an additional two trials.

Included studies-We identified and included 19 eligible studies in this review. Among the 19 included trials the clinical settings were variable. Eight studies took place within the context of surgery: cardiac, vascular or orthopaedic (Bracey 1999; Bush 1997; Carson 1998; Carson 2011; Foss 2009; Grover 2005; Hajjar 2010; Johnson 1992; Lotke 1999; So-Osman 2010). Five trials were in the context of acute blood loss and/or trauma (Blair 1986; Colomo 2008; Fortune 1987; Topley 1956; Zygun 2009), three trials involved patients in critical care units (Hebert 1995; Hebert 1999; Lacroix 2007) and one trial involved leukaemia patients undergoing chemotherapy or stem cell transplantation (Webert 2008).

There was considerable variation with regard to the restrictive transfusion strategies used. These varied from 7.0 to $9.0 \mathrm{~g} / \mathrm{dL}$, with two further trials specifying haematocrit values of $25 \%$ or $30 \%$ (equivalent to haemoglobin levels of around 8.0 and $10.0 \mathrm{~g} / \mathrm{dL}$ respectively). The liberal transfusion triggers varied: $100 \%$ of 'normal red cell volume' (Topley 1956), two units of blood (immediately in one trial (Blair 1986), postoperatively in another (Lotke 1999)) irrespective of clinical state; transfusion sufficient to maintain haemoglobin levels at or above $12.0 \mathrm{~g} / \mathrm{dL}$ (Webert 2008), $10.0 \mathrm{~g} / \mathrm{dL}$ (Bush 1997; Carson 1998; Carson 2011; Foss 2009; Grover 2005; Hebert 1995; Hebert 1999); Hajjar 2010, 9.5 g/dL (Lacroix 2007) and 9.0 g/dL (Bracey 1999; Colomo 2008; Zygun 2009). Two trials specified the liberal triggers as haematocrit levels of 32\% (Johnson 1992) and 40\% (Fortune 1987). One trial compared a new uniform, restrictive transfusion policy with more liberal standard care (So-Osman 2010).

In these trials random allocation was at the level of the patient, not the clinician or clinical unit. Consequently, participating clinicians may have been responsible for patients in both arms of the trials. Ten trials included more than 100 patients. Only one trial included over 1000 patients (Carson 2011). A total of 6264 trial participants were included in this systematic review. 
Excluded studies-One randomised controlled trial was confined to patients with sickle cell disease and was excluded as the trigger was based on the level of $\mathrm{HbS}$, not the haemoglobin or haematocrit level (Vichinsky 1995).

\section{Risk of bias in included studies}

For further details regarding the performance of the studies against each domain, please see the 'Risk of bias' tables. A summary of the information in the tables is given below.

Additionally, a visual summary of judgements about each methodological quality item for each included trial is shown in Figure 2 and Figure 3.

Sequence generation (selection bias)-We judged the risk of bias for this item to be low for nine trials, eight of which used computer randomisation and one which used a table of random numbers to generate the allocation sequence for the patients. One trial based the randomisation sequence on hospital record number and we judged it to be at high risk of bias, while the remaining nine trials presented insufficient information to assess the adequacy of sequence generation and we rated them as unclear.

Allocation-We judged the risk of bias for this item to be low for four trials which used central allocation. We rated 13 trials as unclear; seven used sealed envelopes, however, it was not clear if they were used with appropriate safeguards (e.g. sequentially numbered) to adequately conceal allocation. The other six rated as unclear did not present any information regarding allocation concealment. We rated two trials as being at high risk of bias for this domain.

Blinding-The nature of the intervention means that blinding of clinicians involved in the care and administration of blood transfusions would not have been feasible. The extent to which this could have biased the results is unclear, thus we have rated none of the studies as being at low risk of bias for this domain. However, blind outcome assessment was reported as being used in eight trials.

Incomplete outcome data-We rated 14 trials as being at low risk of bias for this domain as they either had no missing data or performed intention-to-treat analyses. A small number of exclusions were reported in the remaining five trials, although the extent to which this may have introduced bias is uncertain, thus we rated these trials as unclear.

Selective reporting -We could not find any evidence of reporting bias. Although we did not have access to the trial protocols for the majority of trials, the results for the primary and secondary outcomes, as described in the methods sections of each trial, were clearly and concisely reported. Trial protocols were available for the trials with which the authors had some degree of involvement (Carson 1998; Carson 2011; Hebert 1995; Hebert 1999; Lacroix 2007).

Other potential sources of bias-We identified no other sources of bias. 


\section{Effects of interventions}

Eighteen of the 19 trials presented data suitable for inclusion in the meta-analyses. One trial evaluated changes in brain tissue oxygen and other metabolic parameters (Zygun 2009).

Despite the heterogeneity in the methods and transfusion triggers reported in these randomised trials, it was possible to aggregate data from the following outcomes: exposure to red cell transfusion, exposure to red cell transfusion (allogeneic), average volume of red cells transfused in all patients, average volume of red cells transfused in transfused patients, haemoglobin concentration, cardiac events, myocardial infarction, pulmonary oedema, cerebrovascular accident, pneumonia, infection, mortality at 30 days, hospital mortality, overall length of hospital stay and intensive care unit length of hospital stay.

\section{Proportion of patients transfused-Analysis 1.1}

Data on the frequency of transfusions were available from 17 trials. On average, the implementation of a restrictive transfusion trigger reduced the risk of receiving a red cell transfusion by a relative $39 \%$ (risk ratio (RR) $0.61,95 \%$ confidence interval $(\mathrm{CI}) 0.52$ to $0.72)$. Heterogeneity between these trials was statistically significant $\left(\mathrm{Chi}^{2}=238.95, \mathrm{df}=16\right.$ $\left.(\mathrm{P}<0.00001) ; \mathrm{I}^{2}=93 \%\right)$.

The funnel plot displays an absence of smaller studies showing patients at elevated risk of receiving a transfusion with more restrictive transfusion triggers.

\section{Quantity of red cells transfused-Analysis 1.7}

The quantities of blood transfused were reported in eight trials. The use of a restrictive transfusion trigger resulted in an average saving of 1.19 units of red cells per transfused patient (mean difference (MD) $-1.19,95 \% \mathrm{CI}-1.85$ to -0.53 ). Heterogeneity between these trials was statistically significant $\left(\mathrm{Chi}^{2}=84.46, \mathrm{df}=7(\mathrm{P}<0.00001) ; \mathrm{I}^{2}=92 \%\right)$. One trial transfused autologous blood (Lotke 1999).

\section{Haemoglobin or haematocrit concentration-Analysis 2.1}

Postoperative haemoglobin or haematocrit levels were reported in 12 trials. In five trials the timing of measurement varied (the average measured over a number of days after hospitalisation (or operation)). In five trials a single value prior to discharge was recorded and in one trial a single value after the first transfusion was recorded. When we pooled data (without regard to timing, which was consistent within studies) patients assigned to a restrictive strategy had haemoglobin concentration on average $1.5 \%$ lower than patients assigned to a liberal transfusion strategy (MD $-1.48,95 \% \mathrm{CI}-1.92$ to -1.03$)$. Heterogeneity between these trials was statistically significant $\left(\mathrm{Chi}^{2}=752.16\right.$, $\mathrm{df}=11(\mathrm{P}<0.00001) ; \mathrm{I}^{2}=$ $99 \%)$.

Mortality-Analysis 3.2; Analysis 3.5

Thirty-day mortality data were reported for 11 trials. There was no statistically significant difference in 30-day mortality between restrictive and liberal transfusion strategies (RR 
$0.85,95 \%$ CI 0.70 to 1.03$)$. Heterogeneity between these trials was not statistically significant $\left(\mathrm{Chi}^{2}=5.90, \mathrm{df}=9(\mathrm{P}=0.75) ; \mathrm{I}^{2}=0 \%\right)$. It should be noted that one study of patients in intensive care (Hebert 1999) contributed 52.0\% and the study in patients with hip fracture (Carson 2011) contributed $23.4 \%$ of the weight in the meta-analysis of this outcome. Hospital mortality was $23 \%$ lower in patients in the restrictive compared to the liberal transfusion strategy (RR 0.77, 95\% CI 0.62 to 0.95 ). Heterogeneity between the trials was not significant $\left(\mathrm{Chi}^{2}=1.35, \mathrm{df}=3(\mathrm{P}=0.72) ; \mathrm{I}^{2}=0 \%\right)$.

Hospital length of stay-Analysis 4.1

Eight trials reported data for length of hospital stay. These data indicated that the reduction in red blood cell transfusion was not associated with a prolongation of hospital stay (MD 0.11 days, $95 \% \mathrm{CI}-0.16$ to 0.38 days). Heterogeneity between these trials was not statistically significant $\left(\mathrm{Chi}^{2}=6.28, \mathrm{df}=7(\mathrm{P}=0.51) ; \mathrm{I}^{2}=0 \%\right)$. It is unclear if length of hospital stay included only patients who survived.

Functional recovery-Analysis 5.1; Analysis 5.2

Two trials reported functional outcomes in hip fracture patients (Carson 2011; Foss 2009). The functional measures were different in the trials and could not be combined. Death or inability to walk at 30 days (RR $1.05,95 \%$ CI 0.95 to 1.15 ) or 60 days (RR $0.99,95 \%$ CI 0.88 to 1.11 ) was not significant between transfusion strategies. No other measures of function were significantly different between transfusion strategies.

\section{Cardiac events-Analysis 6.1}

Seven trials reported data on cardiac events. The rates of cardiac events (myocardial infarction, cardiac arrhythmias, cardiac arrest, pulmonary oedema and angina) were not increased significantly by the use of restrictive transfusion strategies (RR $0.96,95 \%$ CI 0.70 to 1.32$)$. Heterogeneity between these trials was statistically significant $\left(\mathrm{Chi}^{2}=16.87, \mathrm{df}=6\right.$ $\left.(\mathrm{P}=0.010) ; \mathrm{I}^{2}=64 \%\right)$. It is likely that patients were counted in more than one category of this composite outcome.

\section{Myocardial infarction-Analysis 6.2}

Eight trials reported data on myocardial infarction (fatal and non-fatal). The use of a restrictive transfusion threshold did not appear to impact adversely on the rates of myocardial infarction (RR $0.88,95 \%$ CI 0.38 to 2.04 ). There was no statistical heterogeneity between trials $\left(\mathrm{Chi}^{2}=10.42, \mathrm{df}=7(\mathrm{P}=0.17) ; \mathrm{I}^{2}=33 \%\right)$.

\section{Pulmonary oedema-Analysis 6.3}

Five trials reported data for pulmonary oedema. There was no significant difference between the restrictive and liberal transfusion strategies (RR $0.72,95 \%$ CI 0.31 to 1.70 ).

Heterogeneity between the trials was significant $\left(\mathrm{Chi}^{2}=11.40, \mathrm{df}=4(\mathrm{P}=0.02) ; \mathrm{I}^{2}=65 \%\right)$.

Cerebrovascular accident - stroke-Analysis 6.4 
Five trials reported on stroke. There was no significant difference between transfusion strategies (RR $0.84,95 \%$ CI 0.47 to 1.49 ). Heterogeneity between the trials was not significant $\left(\mathrm{Chi}^{2}=2.61, \mathrm{df}=4(\mathrm{P}=0.63) ; \mathrm{I}^{2}=0 \%\right)$.

Pneumonia-Analysis 6.5

Five trials reported data for pneumonia. In contrast to overall infections; there was no significant difference between transfusion strategies (RR 0.93, 95\% CI 0.76 to 1.15 ). Heterogeneity between these trials was not statistically significant $\left(\mathrm{Chi}^{2}=2.51, \mathrm{df}=4(\mathrm{P}=\right.$ $0.64) ; I^{2}=0 \%$ ).

Infections-Analysis 6.8

Six trials reported data for infections. The rate of infections was decreased by $19 \%$ with the use of restrictive transfusion strategies although the results are not significant (RR 0.81, 95\% CI 0.66 to 1.00$)$. Heterogeneity between these trials was not statistically significant $\left(\mathrm{Chi}^{2}=\right.$ $\left.5.70, \mathrm{df}=5(\mathrm{P}=0.34) ; \mathrm{I}^{2}=12 \%\right)$.

Other outcomes-A number of other potentially relevant clinical outcomes were reported in individual trials, including thromboembolism, multi-organ failure, mental confusion and delayed wound healing. Although there were no statistically significant differences between restrictive and liberal transfusion strategies for any of these outcomes, the overall event rates were low. Interestingly, one trial (Blair 1986) reported a decreased risk of re-bleeding in patients randomised to a restrictive transfusion strategy compared to patients randomised to a liberal transfusion strategy (RR 0.10, 95\% CI 0.01 to 0.75 ). Where reported, heart rates, cardiac index and systemic vascular resistance also appeared to be unaffected (Bush 1997; Johnson 1992).

Sensitivity analyses-We performed a post hoc sensitivity analysis to explore the effects of the inclusion of data from the Webert 2008 trial in the pooled analyses. Webert 2008 explored whether a higher transfusion threshold would be beneficial for patients with acute leukaemia, unlike the other included studies which investigated the safety of a lower transfusion threshold. When we excluded data from Webert 2008 from the pooled analysis of blood transfusion exposure, the risk ratio was reduced slightly from 0.63 (95\% CI 0.54 to $0.74)$ to 0.61 (95\% CI 0.53 to 0.71$)$. Heterogeneity between these trials remained statistically significant $\left(\mathrm{Chi}^{2}=96.82, \mathrm{df}=13, \mathrm{P}<0.00001 ; \mathrm{I}^{2}=87 \%\right)$.

\section{DISCUSSION}

We identified 19 randomised controlled trials evaluating different red cell transfusion triggers carried out over a 55-year time period. These trials enrolled 6264 patients from divergent patient populations. The results of the meta-analyses indicated that, on average, restrictive transfusion strategies were associated with a reduction of more than one-third in the number of patients receiving blood, a red cell transfusion requirement that was approximately one unit lower, and a haemoglobin concentration (average postoperative) that 
was around $1.5 \mathrm{~g} / \mathrm{dL}$ lower than in the liberal transfusion group. However, such results need tempering against the significant heterogeneity of the trials assessed.

\section{Sources of heterogeneity}

For the primary outcome (the number of patients exposed to blood transfusion) we observed substantial heterogeneity. The variation was in terms of the size (but not the direction) of the treatment effect. The individual trials (with five exceptions: Bush 1997; Grover 2005; SoOsman 2010; Topley 1956; Webert 2008) found that a restrictive transfusion trigger statistically significantly reduced the probability of receiving a red cell transfusion, with the risk ratio estimates ranging from 0.21 to 0.96 . However, some confidence intervals were non-overlapping. Heterogeneity might have been anticipated, as the clinical settings and the transfusion triggers differed between trials. In addition, the primary outcome in the metaanalysis, the decision to transfuse, is a practice variable and involves a degree of subjectivity. It cannot be argued that the treatment effect varied according to the rate of red cell transfusion in the control groups, as most patients (84\%) in the liberal transfusion groups received red cell transfusions.

The level of the transfusion trigger between trials does not seem to account for the variation in treatment effect size; the relative risk appeared unrelated to it. However, the degree of difference within trials, between the transfusion triggers of the intervention and control groups, may account for some of the variation observed in the treatment effect size. The effect estimates for trials comparing well-defined transfusion rates that differed by $2.0 \mathrm{~g} / \mathrm{dL}$ tended to be larger than the estimates for trials comparing thresholds differing by less than $2.0 \mathrm{~g} / \mathrm{dL}$. Although these apparent 'associations' may also be due to the play of chance, such observations warrant further discussion.

Two trials (Blair 1986; Lotke 1999) showed greater benefit (in favour of restrictive transfusion strategies) in reducing exposure to red cell transfusion, than any of the other trials. These two trials appeared to add considerably to the observed heterogeneity. In Blair 1986 the control group were routinely transfused (as dictated by the trial protocol) at least two units of blood within 24 hours of hospital admission, regardless of their $\mathrm{Hb}$ level and clinical state, whereas the intervention group were only transfused blood when their $\mathrm{Hb}$ concentration fell below $8.0 \mathrm{~g} / \mathrm{dL}$ or they displayed signs of shock. For this trial (Blair 1986) the transfusion exposure rate for the intervention group was $19 \%$ compared to $100 \%$ for the control group. For the trial conducted by Lotke 1999 the control group received all of their preoperatively donated autologous (PAD) blood ( 2 units/patient) immediately after surgery (as dictated by the trial protocol) whereas the patients in the intervention group were not transfused their PAD blood unless their $\mathrm{Hb}$ concentration fell to less than $9.0 \mathrm{~g} / \mathrm{dL}$. For this trial (Lotke 1999) the transfusion exposure rate for the intervention group was 26\% compared to $100 \%$ in the control group.

Five trials (Bush 1997; Grover 2005; So-Osman 2010; Topley 1956; Webert 2008) failed to show a statistically significant reduction in red cell transfusion rates. For Bush 1997 and Webert 2008 protocol violations may have impacted significantly on the rates of transfusion in the intervention groups. In Bush 1997, patients randomised to the intervention group were to be transfused allogeneic red cells, and in some instances autologous red cells, when their 
$\mathrm{Hb}$ concentration fell below $9.0 \mathrm{~g} / \mathrm{dL}$; the control group were transfused when their $\mathrm{Hb}$ concentration fell below $10.0 \mathrm{~g} / \mathrm{dL}$. The authors of Bush 1997 conceded that not all the patients randomised to the restrictive transfusion strategy reached the transfusion threshold level of $\mathrm{Hb}<9.0 \mathrm{~g} / \mathrm{dL}$ because they either had minimal intra-operative blood loss or were excessively transfused by the anaesthetists or surgeons. The later may account for the relatively small difference in transfusion rates between the intervention and control groups ( $88 \%$ versus $80 \%$, respectively). In Webert 2008, patients were allocated to receive RBC transfusion when their $\mathrm{Hb}$ level fell below $8.0 \mathrm{~g} / \mathrm{dL}$ in the intervention group or $12.0 \mathrm{~g} / \mathrm{dL}$ in the control. The trial authors note that a number of patients received transfusion before their assigned threshold had been reached; compliance with the assigned threshold was achieved only $64 \%$ of the time in the intervention and $70 \%$ of the time in the control group. This also may explain the similar transfusion rates observed in the two groups ( $90 \%$ and $94 \%$ for the restrictive and liberal groups, respectively). The trial by So-Osman 2010 compared a new age-dependent restrictive transfusion policy with the standard policy used in the three participating hospitals. Deviation from the assigned trigger was not found to be a problem, however differences in the transfusion threshold forming the standard policy of the hospitals may explain the lack of difference observed in transfusion rates (36\% and 39\% for intervention and control, respectively). The trial by Topley 1956 was designed so that one group of patients ('under-transfused' group) would have a red cell volume (RCV) of $70 \%$ to $80 \%$ of normal at the end of resuscitation, whilst the control group ('adequately transfused' group) would have a RCV of $100 \%$ of normal or over at the end of resuscitation. However, as reported, in practice these objectives were achieved with an accuracy of only $\pm 20 \%$.

There is no evidence to suggest that clinical setting or adequacy of allocation concealment explains the variability in the effect estimates.

\section{Adverse events and other outcomes}

None of the outcomes evaluated, including mortality, cardiac morbidity, infections and length of hospital stay, appear to be adversely affected by the lower use of red cell transfusions. In contrast, the evidence raises the possibility of harm associated with liberal transfusion. In-hospital mortality and infections were $23 \%$ and $19 \%$ higher in patients receiving liberal transfusion, respectively. However, these findings should be interpreted cautiously. Mortality was not significantly different for the other time periods examined. The infection results were borderline significant and the risk of pneumonia was not elevated. Although very little heterogeneity was seen for the outcome variable mortality, the metaanalysis was dominated by two trials (Carson 2011; Hebert 1999) that contributed $75 \%$ of the statistical information.

These data are quite informative and support the recent move to more restrictive transfusion practices. Trials have now been performed in several settings where transfusion is widely used. Trials in adult and paediatric intensive care unit (ICU) patients confirm the safety of a $7.0 \mathrm{~g} / \mathrm{dL}$ threshold in patients with severe acute illness. One trial in elderly hip fracture patients undergoing surgery and with extensive co-morbidity including underlying cardiovascular disease suggests that restrictive transfusion to $8.0 \mathrm{~g} / \mathrm{dL}$ is safe as well. This 
trial is also the first to demonstrate that liberal transfusion does not improve functional recovery.

\section{Sources of bias}

We performed extensive searches in an attempt to identify all eligible trials irrespective of publication status. Despite these efforts, inspection of the funnel plot (Figure 1) raises the possibility of publication bias or other small study biases affecting the exposure to blood transfusion outcome.

Our analyses demonstrate that only two trials in adults (Carson 2011; Hebert 1999) were adequately powered to evaluate the impact of different transfusion strategies on mortality, morbidity and function. Carson 2011 was the largest trial performed and included 2016 patients undergoing surgical repair for hip fracture. Hebert 1999 was the next largest study, involving 838 intensive care patients. Given this, the meta-analysis of mortality is dominated by studies in elderly surgical and intensive care patients and therefore it is uncertain if the results can be applied to other clinical settings. In paediatric intensive care unit patients there was no difference in new or progressive multiple-organ dysfunction syndrome (Lacroix 2007).

Several important clinical outcomes have not been adequately evaluated in the trials published to date. The studies evaluating myocardial infarction are too small to detect moderate differences and infection results are inconsistent. Observational data suggest that higher blood counts may be associated with less postoperative delirium (Weiskopf 2000).

This systematic review found new evidence of the safety of restrictive transfusion triggers in important subsets of patients with underlying cardiovascular disease (Carson 2011). Overall, the rates of cardiac events in this meta-analysis were not increased by the use of restrictive transfusion triggers; the trial was too small to detect small to moderate effects. However, evidence is still lacking in other important subsets of patients, including those with acute cardiovascular disease, renal failure and haematological disorders. Some guidelines recommend transfusion for symptoms or haemodynamic instability, rather than for a specific trigger haemoglobin level (AAGBI 2008; ASA 2006; ASBT 2001; Napolitano 2009;

NBUGI 2001). This approach to transfusion was tested in a pilot study involving 84 patients (Carson 1998) and in a trial involving 2016 patients (Carson 2011) in which patients could be transfused with symptoms (cardiac chest pain, congestive heart failure and orthostatic hypotension or tachycardia unresponsive to adequate fluid challenge) or haemoglobin concentration less than $8.0 \mathrm{~g} / \mathrm{dL}$. These studies found no difference in functional recovery, mortality or morbidity in patients in the restrictive (symptomatic) transfusion group.

The results of these trials need to be viewed against six large observational studies that compared clinical outcomes at varying haemoglobin levels in transfused and non-transfused patients, and found conflicting results. In a study of 2202 patients undergoing coronary bypass surgery, the liberal transfusion group had a higher incidence of myocardial infarction than the conservative transfusion group (Spiess 1998). In a study of 8787 hip fracture patients, there was no difference in short or long-term mortality between patients transfused and not transfused down to a post-operative haemoglobin of $8.0 \mathrm{~g} / \mathrm{dL}$ (Carson 1998). In a 
study of 4470 ICU patients, mortality was reduced in patients receiving transfusion of up to six units of blood (Hebert 1997). A retrospective study of 78,974 Medicare beneficiaries (Wu 2001) found that blood transfusion was associated with a lower short-term mortality rate among elderly patients with acute myocardial infarction if the haematocrit on admission was $30 \%$ or lower and that blood transfusion may be effective with a haematocrit as high as $33 \%$ on admission. A study of 310,311 patients 65 years or older who underwent major noncardiac surgery found a $1.6 \%$ increase in 30-day postoperative mortality for each $1 \%$ decrease in preoperative haematocrit (Wu 2007). A study of 239,286 patients 65 years or older who underwent major non-cardiac surgery found intraoperative blood transfusion was associated with a reduction in mortality in patients with preoperative haematocrit levels of < $24 \%$ or in those with blood loss $>500 \mathrm{cc}$ (Wu 2010). The main limitation of these observational studies is that there may be residual confounding by indication, despite the extensive statistical adjustment of the results. It is possible that differences in patient characteristics between transfused and non-transfused patients may not be identified, or adequately adjusted for. This point is emphasised by the fact that a randomised controlled trial (Hebert 1999) and an observational study (Hebert 1997) in intensive care patients, performed by the same group of investigators, came to opposite conclusions. Despite recent assertions to the contrary (Benson 2000; Concato 2000), we believe that adequately powered, rigorously performed, randomised clinical trials are the only way of overcoming these limitations.

A study presented at the Cochrane Colloquium in Lyon, France (9-13 October 2001) (Henry 2001a) highlighted the significant discrepancies in the results reported by randomised controlled trials compared to those reported by observational studies. This and other studies (Ioannidis 2001) have shown that disagreements in the magnitude of treatment effect between randomised controlled trials (RCTs) and observational studies are common. The authors of Henry 2001a analysed the data from studies of various interventions including: preoperative autologous donation (PAD), acute normovolemic haemodilution, cell salvage, laparoscopic cholecystectomy, hormone replacement therapy and antioxidant therapy. For PAD alone, the observational studies' $(n=41)$ estimate of treatment effect (risk ratio) for the number of patients exposed to allogeneic blood transfusion was 0.30 (95\% confidence interval (CI) 0.26 to 0.35 ) compared to 0.39 (95\% CI 0.27 to 0.57 ) for the RCTs $(n=7)$. For this intervention (PAD) there appears to be reasonable agreement between the results of the observational studies and the randomised controlled trials. However, the observational studies have appeared to over-estimate the magnitude of the treatment effect. Observational studies of the other interventions have tended to under-estimate the magnitude of treatment effect. Although the results obtained from well-conducted observational studies are extremely valuable, making inferences from observational data sets is problematic, as the sources of error and bias that afflict observational studies do not afflict randomised trials (Henry 2001a).

Conducting randomised clinical trials, where one intervention is a clinical policy regarding red cell transfusion, is demanding. Masking (blinding) the use of transfusion at the bedside is difficult to achieve unless study personnel are assigned to each patient, an expensive procedure. Outcomes that are determined by observers who are blind to the treatment group is probably the most rigorous approach that is practical. This approach was reported in only 
eight of the trials reviewed here (Carson 1998; Carson 2011; Foss 2009; Grover 2005; Hajjar 2010; Johnson 1992; Lotke 1999; Webert 2008). Maintaining the integrity of the randomisation process becomes important if the trial is not to over-estimate the benefit of the intervention (Schulz 1995). Some studies in this review did not report the methods used to conceal the allocation sequence from the treating clinicians. Four trials (Carson 1998; Carson 2011; Lacroix 2007; Webert 2008) used a centralised allocation and four others (Bush 1997; Foss 2009; Hebert 1999; So-Osman 2010) used randomisation codes in sealed envelopes. The latter method has the potential to be unmasked, leading to the potential for selection bias in the inclusion of patients in the trials (Schulz 1995).

The transfusion policies reviewed here represent fairly small modifications to routine clinical practice. They are consistent with the recommendations of published clinical practice guidelines (AAGBI 2008; ASA 2006; ASBT 2001; BCTMAG 2003; Napolitano 2009; NBUGI 2001). The transfusion triggers (in terms of haemoglobin levels) were most often in the range of 8.0 to $9.0 \mathrm{~g} / \mathrm{dL}$, although values as low as $7.0 \mathrm{~g} / \mathrm{dL}$ were assessed. In fact, the 'restrictive' transfusion triggers in some trials were equivalent to the 'liberal triggers' used in other trials. Nevertheless, the trials documented significant reductions in the rates of red cell transfusion and worthwhile blood conservation. These effects are similar to what has been documented in meta-analyses of trials of blood sparing techniques, such as cell salvage and anti-fibrinolytic drugs (Carless 2010; Henry 2011b). Adoption of a conservative transfusion threshold appears to be as effective as these technologies in avoiding the need for transfusion and is likely to cost less. In summary, a restrictive transfusion trigger reduces the risk of exposure to red blood cell transfusion and the total number of units transfused. The currently published evidence suggests that restrictive transfusion triggers do not adversely affect mortality, cardiac morbidity, function or length of hospital stay. For the present we recommend the use of a restrictive transfusion trigger, but suggest using caution in patients from high-risk groups such as acute coronary syndrome as there is currently no evidence from randomised controlled trials to guide treatment. In countries where there are serious doubts about the safety of donated blood, because of inadequate testing for viral pathogens, the existing data may constitute a stronger basis for avoiding red cell transfusion in many clinical settings.

\section{AUTHORS' CONCLUSIONS}

\section{Implications for practice}

In patients who do not have acute coronary artery disease, blood transfusion can probably be withheld in the presence of haemoglobin levels as low as $7.0 \mathrm{~g} / \mathrm{dL}$ to $8.0 \mathrm{~g} / \mathrm{dL}$ as long as there is no notable bleeding. The benefits of minimising allogeneic red cell transfusion are likely to be greatest where there is doubt about the safety of the blood supply.

\section{Implications for research}

Future trials of transfusion 'triggers' should include patients with acute coronary syndrome, elderly patients recovering from acute illness, patients with gastrointestinal bleeding, coagulopathy or haemorrhagic shock, and patients with traumatic brain injury. Trials are 
also needed that evaluate lower haemoglobin concentrations such as $6.0 \mathrm{~g} / \mathrm{dL}$. Trials should be large enough to measure the impact that lower thresholds have on clinical outcomes.

\section{Acknowledgments}

We acknowledge the contribution of Suzanne Hill (World Health Organization), the first author of the original version and the 2004 update of the review. We also acknowledge the contribution of Kim Henderson in the original review first published in 2000. We also acknowledge David Henry (Institute of Clinical Evaluative Sciences) and Brian McClelland who co-wrote reviews up to 2010; Katharine Ker (London School of Hygiene \& Tropical Medicine) undertook the following tasks for the 2010 update: screened search output, obtained articles, applied inclusion/exclusion criteria to retrieved papers, assessed risk of bias, extracted data, performed data analysis and revised the text of the review. We thank Karen Blackhall (Injuries Group Trials Search Co-ordinator) who ran the electronic database searches in 2009 and 2011.

\section{SOURCES OF SUPPORT}

Internal sources

- $\quad$ No sources of support supplied

External sources

- $\quad$ NSW Ministerial Advisory Committee on Quality in Health Care, Australia.

- $\quad$ NSW Health Department, Australia.

\section{Appendix 1. Search strategy}

\section{Cochrane Injuries Group's Specialised Register (searched 1 February 2011)}

(Blood or "Red blood cell" or "Red blood cells" or RBC) and (therap* or transfus*) and (polic* ${ }^{*}$ or practice or protocol* or trigger* or threshold* or indicator* or strateg* or criteri* or standard* or restrict* or liberal* or management or program*)

\section{Cochrane Central Register of Controlled Trials (CENTRAL) (The Cochrane Library 2011, Issue 1)}

\#1 MeSH descriptor Blood Transfusion, this term only with qualifiers: MT,ST

\#2 transfus* near5 (polic*or practic* or protocol* or trigger* or threshold*or indicator* or strateg* or criteri* or standard*)

\#3 (Red blood cell* or RBC) near5 (polic*or practic* or protocol* or trigger* or threshold*or indicator* or strateg* or criteri* or standard*) and (therap* or transfus*)

\#4 (H?emoglobin or h?emocrit or HB or HCT) near5 (polic*or practic* or protocol* or trigger* or threshold*or indicator* or strateg* or criteri* or standard*)

\#5 transfus* near5 (restrict* or liberal*)

\#6 (blood transfus*) near3 (management or program*)

\#7 (\#1 OR \#2 OR \#3 OR \#4 OR \#5 OR \#6) 


\section{MEDLINE (Ovid) 1948 to January Week 32011}

1. *Blood Transfusion/

2. ((Red blood cell* or RBC) adj3 (therap* or transfus*)).mp.

3. 1 or 2

4. $\exp$ Reference Standards/

5. standards.fs.

6. methods.fs.

7. 4 or 5 or 6

8. 3 and 7

9. (transfus* adj5 (polic*or practic* or protocol* or trigger* or threshold*or indicator* or strateg* or criteri* or standard*)).mp.

10. ((Red blood cell* or RBC) adj5 (polic*or practic* or protocol* or trigger* or threshold*or indicator* or strateg* or criteri* or standard*)).mp.

11. ((H?emoglobin or h?emocrit or HB or HCT) adj5 (polic*or practic* or protocol* or trigger* or threshold*or indicator* or strateg* or criteri* or standard*)).mp.

12. (transfus* adj5 (restrict* or liberal*)).mp.

13. ((blood or transfus*) adj3 (management or program*)).mp.

14. 8 or 9 or 10 or 11 or 12 or 13

15. randomi?ed.ab,ti.

16. randomized controlled trial.pt.

17. controlled clinical trial.pt.

18. placebo.ab.

19. clinical trials as topic.sh.

20. randomly.ab.

21. trial.ti.

22. 15 or 16 or 17 or 18 or 19 or 20 or 21

23. (animals not (humans and animals)).sh.

24. 22 not 23

25. 24 and 14

\section{EMBASE (Ovid) 1980 to 2011 Week 04}

1. *Blood Transfusion/

2. ((Red blood cell* or RBC) adj3 (therap* or transfus*)).mp. 
3. 1 or 2

4. exp standard/

5. 3 and 4

6. (transfus* adj5 (polic*or practic* or protocol* or trigger* or threshold*or indicator* or strateg* or criteri* or standard*)).mp.

7. ((Red blood cell* or RBC) adj5 (polic*or practic* or protocol* or trigger* or threshold*or indicator* or strateg* or criteri* or standard*)).mp.

8. ((H?emoglobin or h?emocrit or HB or HCT) adj5 (polic*or practic* or protocol* or trigger* or threshold*or indicator* or strateg* or criteri* or standard*)).mp.

9. (transfus* adj5 (restrict* or liberal*)).mp.

10. ((blood or transfus*) adj3 (management or program*)).mp.

11. 5 or 6 or 7 or 8 or 9 or 10

12. exp Randomized Controlled Trial/

13. exp controlled clinical trial/

14. randomi?ed.ab,ti.

15. placebo.ab.

16. *Clinical Trial/

17. randomly.ab.

18. trial.ti.

19. 12 or 13 or 14 or 15 or 16 or 17 or 18

20. exp animal/not (exp human/and exp animal/)

21. $19 \operatorname{not} 20$

22. 11 and 21

\section{ISI Web of Science: Science Citation Index Expanded (SCI-EXPANDED) (1970 to February 2011) and ISI Web of Science: Conference Proceedings Citation Index - Science (CPCI-S) (1990 to February 2011)}

\#1 TS=((Blood or "Red blood cell" or "Red blood cells" or RBC or Hemoglobin* or haemoglobin* or haemocrit or hemocrit or HB or HCT) SAME transfus*)

\#2 TS=(polic* or practice or protocol* or trigger* or threshold* or indicator* or strateg* or criteri* or standard* or restrict* or liberal* or management or program*)

$\# \mathbf{3} \quad \# 1$ and \#2 
\#4 TS=(randomised OR randomized OR randomly OR random order OR random sequence OR random allocation OR randomly allocated OR at random OR randomized controlled trial $)$ OR Topic $=($ controlled clinical trial OR controlled trial OR clinical trial OR placebo)

\#5 TS=((singl* OR doubl* OR trebl* OR tripl*) SAME (blind* OR mask*))

\#6 \#2 or \#3

\#7 \#3 and \#6

\#8 Topic=(human*)

\#9 \#7 and \#8

\section{CHARACTERISTICS OF STUDIES}

\section{Characteristics of included studies [ordered by study ID]}

Blair 1986

\begin{tabular}{|c|c|c|}
\hline Methods & \multicolumn{2}{|c|}{ Randomised controlled trial } \\
\hline \multirow[t]{3}{*}{ Participants } & \multicolumn{2}{|c|}{$\begin{array}{l}50 \text { consecutive patients with severe upper gastrointestinal haemorrhage were randomised to } 1 \text { of } \\
2 \text { groups: }\end{array}$} \\
\hline & \multicolumn{2}{|c|}{ Liberal group: $n=24$; mean $(\mathrm{SD})$ age $=64(17.6)$ years } \\
\hline & \multicolumn{2}{|c|}{ - $\quad$ Restrictive group: $\mathrm{n}=26 ;$ mean $(\mathrm{SD})$ age $=60(17.8)$ years } \\
\hline Interventions & \multirow{2}{*}{\multicolumn{2}{|c|}{$\begin{array}{l}\text { - Liberal group received at least } 2 \text { units of red blood cells immediately at admission } \\
\text { and during their first } 24 \text { hours in hospital. } \\
\text { - Restrictive group were not transfused red blood cells unless the Hb was less than } 8.0 \\
\text { g/dL or shock persisted after initial resuscitation with Haemaccel }\end{array}$}} \\
\hline & & \\
\hline Outcomes & \multicolumn{2}{|c|}{$\begin{array}{l}\text { Outcomes reported: blood usage (units), re-bleeding, mortality, clotting times, Hct on } \\
\text { admission/discharge, kaolin cephalin clotting time after } 24 \text { hours, impedance clotting time after } \\
24 \text { hours }\end{array}$} \\
\hline \multicolumn{3}{|l|}{ Notes } \\
\hline \multicolumn{3}{|l|}{ Risk of bias } \\
\hline Bias & Authors' judgement & Support for judgement \\
\hline $\begin{array}{l}\text { Random sequence } \\
\text { generation } \\
\text { (selection bias) }\end{array}$ & Unclear risk & No information reported \\
\hline $\begin{array}{l}\text { Allocation } \\
\text { concealment } \\
\text { (selection bias) }\end{array}$ & Unclear risk & No information reported \\
\hline $\begin{array}{l}\text { Blinding } \\
\text { (performance bias } \\
\text { and detection bias) } \\
\text { All outcomes }\end{array}$ & Unclear risk & No information reported \\
\hline $\begin{array}{l}\text { Incomplete } \\
\text { outcome data } \\
\text { (attrition bias) } \\
\text { All outcomes }\end{array}$ & Low risk & No missing data \\
\hline
\end{tabular}




\begin{tabular}{lll}
$\begin{array}{l}\text { Selective reporting } \\
\text { (reporting bias) }\end{array}$ & Unclear risk & - \\
\hline Other bias & Low risk & - \\
\hline
\end{tabular}

\section{Bracey 1999}

\begin{tabular}{|c|c|c|}
\hline Methods & \multicolumn{2}{|c|}{ Randomised controlled trial } \\
\hline \multirow[t]{3}{*}{ Participants } & \multicolumn{2}{|c|}{$\begin{array}{l}428 \text { consecutive patients undergoing elective primary coronary artery bypass graft surgery were } \\
\text { randomly assigned to } 1 \text { of } 2 \text { groups: }\end{array}$} \\
\hline & \multicolumn{2}{|c|}{ - Liberal group: $\mathrm{n}=212 ; \mathrm{M} / \mathrm{F}=82 / 18 ;$ mean $(\mathrm{SD})$ age $=61(11)$ years } \\
\hline & \multicolumn{2}{|c|}{ Restrictive group: $\mathrm{n}=216 ; \mathrm{M} / \mathrm{F}=83 / 17 ;$ mean $(\mathrm{SD})$ age $=62(11)$ years } \\
\hline \multirow[t]{2}{*}{ Interventions } & $\begin{array}{l}\text { Liberal gro } \\
\text { who consic } \\
\text { which proł } \\
\text { transfusion }\end{array}$ & $\begin{array}{l}\text { Is on the instructions of their individual physicians, } \\
\text { ment of the patient and the institutional guidelines, } \\
\text { dL as the postoperative threshold for RBC }\end{array}$ \\
\hline & $\begin{array}{l}\text { - } \quad \text { Restrictive } \\
\text { level }<8.0\end{array}$ & transfusion in the postoperative period at a $\mathrm{Hb}$ \\
\hline Outcomes & \multicolumn{2}{|c|}{$\begin{array}{l}\text { Outcomes reported: mortality, length of hospital stay, blood usage (units), blood loss, } \\
\text { complications, infection rates, cardiac events }\end{array}$} \\
\hline \multicolumn{3}{|l|}{ Notes } \\
\hline \multicolumn{3}{|l|}{ Risk of bias } \\
\hline Bias & Authors' judgement & Support for judgement \\
\hline $\begin{array}{l}\text { Random sequence } \\
\text { generation } \\
\text { (selection bias) }\end{array}$ & High risk & $\begin{array}{l}\text { Patients were randomly assigned on the basis of } \\
\text { the last digit of their medical record number }\end{array}$ \\
\hline $\begin{array}{l}\text { Allocation } \\
\text { concealment } \\
\text { (selection bias) }\end{array}$ & High risk & Inadequately concealed (record number) \\
\hline $\begin{array}{l}\text { Blinding } \\
\text { (performance bias } \\
\text { and detection bias) } \\
\text { All outcomes }\end{array}$ & Unclear risk & No information \\
\hline $\begin{array}{l}\text { Incomplete } \\
\text { outcome data } \\
\text { (attrition bias) } \\
\text { All outcomes }\end{array}$ & Low risk & $\begin{array}{l}\text { Intention-to-treat analysis used. A small number of } \\
\text { exclusions were reported }\end{array}$ \\
\hline $\begin{array}{l}\text { Selective reporting } \\
\text { (reporting bias) }\end{array}$ & Unclear risk & - \\
\hline Other bias & Low risk & - \\
\hline
\end{tabular}

\section{Bush 1997}

\begin{tabular}{ll}
\hline Methods & Randomised controlled trial \\
\hline Participants & 99 patients undergoing elective aortic or infrainguinal arterial reconstruction were randomised to \\
& $\begin{array}{c}\text { of } 2 \text { groups: } \\
\quad \quad \text { Liberal group: } \mathrm{n}=49 ; \mathrm{M} / \mathrm{F}=41 / 8 ; \text { mean }(\mathrm{SD}) \text { age }=64(11) \text { years }\end{array}$
\end{tabular}

Cochrane Database Syst Rev. Author manuscript; available in PMC 2014 September 23. 
- $\quad$ Restrictive group: $\mathrm{n}=50 ; \mathrm{M} / \mathrm{F}=32 / 18 ;$ mean $(\mathrm{SD})$ age $=66(10)$ years

\begin{tabular}{|c|c|c|}
\hline Interventions & \multicolumn{2}{|c|}{$\begin{array}{l}\text { Liberal group had their } \mathrm{Hb} \text { concentrations maintained at or above } 10.0 \mathrm{~g} / \mathrm{dL} \\
\text { Restrictive group were transfused only when their } \mathrm{Hb} \text { concentration fell below } 9.0 \\
\mathrm{~g} / \mathrm{dL}\end{array}$} \\
\hline Outcomes & \multicolumn{2}{|c|}{$\begin{array}{l}\text { Outcomes reported: } 30 \text {-day mortality, length of ICU stay, length of hospital stay, blood use } \\
\text { (units), postoperative blood loss, cardiac events, Hct/Hb on admission }\end{array}$} \\
\hline \multicolumn{3}{|l|}{ Notes } \\
\hline \multicolumn{3}{|l|}{ Risk of bias } \\
\hline Bias & Authors' judgement & Support for judgement \\
\hline $\begin{array}{l}\text { Random sequence } \\
\text { generation } \\
\text { (selection bias) }\end{array}$ & Unclear risk & No information \\
\hline $\begin{array}{l}\text { Allocation } \\
\text { concealment } \\
\text { (selection bias) }\end{array}$ & Unclear risk & $\begin{array}{l}\text { Sealed envelopes were chosen at random for } \\
\text { patient assignment }\end{array}$ \\
\hline $\begin{array}{l}\text { Blinding } \\
\text { (performance bias } \\
\text { and detection bias) } \\
\text { All outcomes }\end{array}$ & Unclear risk & $\begin{array}{l}\text { Both surgeons and anaesthesiologists were } \\
\text { informed as to the group of randomisation }\end{array}$ \\
\hline $\begin{array}{l}\text { Incomplete } \\
\text { outcome data } \\
\text { (attrition bias) } \\
\text { All outcomes }\end{array}$ & Low risk & Appears to be complete \\
\hline $\begin{array}{l}\text { Selective reporting } \\
\text { (reporting bias) }\end{array}$ & Unclear risk & - \\
\hline Other bias & Low risk & - \\
\hline
\end{tabular}

Carson 1998

\begin{tabular}{|c|c|c|}
\hline Methods & \multicolumn{2}{|c|}{ Randomised controlled trial } \\
\hline \multirow[t]{3}{*}{ Participants } & \multicolumn{2}{|c|}{$\begin{array}{l}84 \text { hip fracture patients undergoing surgical repair who had postoperative } \mathrm{Hb} \text { levels }<10.0 \\
\text { g/dL were randomly assigned to } 1 \text { of } 2 \text { groups: }\end{array}$} \\
\hline & \multicolumn{2}{|c|}{ Liberal group: $\mathrm{n}=42 ; \mathrm{M} / \mathrm{F}=9 / 33 ;$ mean $(\mathrm{SD})$ age $=81.3(8.1)$ years } \\
\hline & \multicolumn{2}{|c|}{ Restrictive group: $\mathrm{n}=42 ; \mathrm{M} / \mathrm{F}=11 / 31 ;$ mean $(\mathrm{SD})$ age $=83.3(10.8)$ years } \\
\hline \multirow[t]{2}{*}{ Interventions } & $\begin{array}{l}\text { Liberal grc } \\
\text { as much bl }\end{array}$ & $\begin{array}{l}\text { Ip received } 1 \text { unit of packed } \mathrm{RBC} \text { at the time of random assignment and } \\
\text { od as necessary to keep the } \mathrm{Hb} \text { level above } 10.0 \mathrm{~g} / \mathrm{dL}\end{array}$ \\
\hline & $\begin{array}{l}\text { Restrictive } \\
\text { level that }\end{array}$ & $\begin{array}{l}\text { sroup received a RBC transfusion for symptoms of anaemia or for a } \mathrm{Hb} \\
\text { opped below } 8.0 \mathrm{~g} / \mathrm{dL}\end{array}$ \\
\hline Outcomes & \multicolumn{2}{|c|}{$\begin{array}{l}\text { Outcomes reported: mortality, length of hospital stay, blood usage (units), complications, } \\
\text { pneumonia, stroke, thromboembolism }\end{array}$} \\
\hline \multicolumn{3}{|l|}{ Notes } \\
\hline \multicolumn{3}{|l|}{ Risk of bias } \\
\hline Bias & \multicolumn{2}{|c|}{ Authors' judgement Support for judgement } \\
\hline $\begin{array}{l}\text { Random sequence } \\
\text { generation (selection } \\
\text { bias) }\end{array}$ & Low risk & $\begin{array}{l}\text { Randomisation schedules were stratified by clinical site and } \\
\text { cardiovascular disease state. The randomisation was designed in } \\
\text { blocks of } 2 \text { to } 8 \text { patients to avoid imbalance within a site }\end{array}$ \\
\hline
\end{tabular}




\begin{tabular}{lll}
$\begin{array}{l}\text { Allocation } \\
\text { concealment } \\
\text { (selection bias) }\end{array}$ & Low risk & $\begin{array}{l}\text { Study personnel at the clinical sites randomly assigned patients by } \\
\text { contacting the data co-ordinating centre's 24-hour automated } \\
\text { telephone service }\end{array}$ \\
\hline $\begin{array}{l}\text { Blinding } \\
\text { (performance bias } \\
\begin{array}{l}\text { and detection bias) } \\
\text { All outcomes }\end{array}\end{array}$ & Unclear risk & Blinding of observers \\
\hline $\begin{array}{l}\text { Incomplete outcome } \\
\text { data (attrition bias) } \\
\text { All outcomes }\end{array}$ & Low risk & Intention-to-treat analysis used \\
\hline $\begin{array}{l}\text { Selective reporting } \\
\text { (reporting bias) }\end{array}$ & Low risk & - \\
\hline \begin{tabular}{l} 
Other bias \\
\hline
\end{tabular} & Low risk & - \\
\hline
\end{tabular}

Carson 2011

\begin{tabular}{|c|c|c|}
\hline Methods & \multicolumn{2}{|c|}{ Randomised, unblinded, parallel, 2-group multicentre trial } \\
\hline Participants & \multicolumn{2}{|c|}{$\begin{array}{l}\text { Patients } 50 \text { years or older, who are undergoing surgical repair of a hip fracture, with } \mathrm{Hb} \\
\text { concentrations below } 10.0 \mathrm{~g} / \mathrm{dL} \text { within } 3 \text { days after surgery and who have clinical evidence for } \\
\text { cardiovascular disease or cardiovascular risk factors Sample size }=2016\end{array}$} \\
\hline \multirow[t]{2}{*}{ Interventions } & $\begin{array}{l}\text { - Liberal grc } \\
\text { g/dL }\end{array}$ & BC when haemoglobin level dropped below 10.0 \\
\hline & $\begin{array}{l}\text { Restrictive } \\
\text { of anaemic }\end{array}$ & $\begin{array}{l}\text { ') group - receive transfusion if develop symptoms } \\
0 \mathrm{~g} / \mathrm{dL}\end{array}$ \\
\hline Outcomes & \multicolumn{2}{|c|}{$\begin{array}{l}\text { Primary outcome is inability to walk } 10 \text { feet (or across a room) without human assistance or death } \\
\text { prior to closure of the window for the } 60 \text {-day, } 30 \text { and } 60 \text {-day mortality. Other outcomes are Hb } \\
\text { concentration, acute coronary syndrome (ACS), in-hospital myocardial infarction, unstable angina } \\
\text { or death, disposition on discharge, survival, functional measures, fatigue/energy, readmission to } \\
\text { hospital, pneumonia, wound infection, thromboembolism, stroke or transient ischaemic attack }\end{array}$} \\
\hline \multicolumn{3}{|l|}{ Notes } \\
\hline \multicolumn{3}{|l|}{ Risk of bias } \\
\hline Bias & Authors' judgement & Support for judgement \\
\hline $\begin{array}{l}\text { Random } \\
\text { sequence } \\
\text { generation } \\
\text { (selection bias) }\end{array}$ & Low risk & $\begin{array}{l}\text { Data Co-ordinating Center staff prepared } \\
\text { randomisation schedules for each site using } \\
\text { randomly ordered block sizes of } 2,4,6 \text { or } 8\end{array}$ \\
\hline $\begin{array}{l}\text { Allocation } \\
\text { concealment } \\
\text { (selection bias) }\end{array}$ & Low risk & Used an automated telephone randomisation system \\
\hline $\begin{array}{l}\text { Blinding } \\
\text { (performance bias } \\
\text { and detection } \\
\text { bias) } \\
\text { All outcomes }\end{array}$ & Unclear risk & $\begin{array}{l}\text { After random allocation, clinical site staff, clinicians } \\
\text { and patients were not blinded to treatment } \\
\text { assignment. Primary and secondary outcomes were } \\
\text { assessed blinded to treatment assignment }\end{array}$ \\
\hline $\begin{array}{l}\text { Incomplete } \\
\text { outcome data } \\
\text { (attrition bias) } \\
\text { All outcomes }\end{array}$ & Low risk & Intention-to-treat analysis \\
\hline $\begin{array}{l}\text { Selective } \\
\text { reporting } \\
\text { (reporting bias) }\end{array}$ & Low risk & - \\
\hline Other bias & Low risk & - \\
\hline
\end{tabular}

Colomo 2008

Cochrane Database Syst Rev. Author manuscript; available in PMC 2014 September 23. 


\begin{tabular}{|c|c|c|}
\hline Methods & \multicolumn{2}{|c|}{ Randomised controlled trial } \\
\hline \multirow[t]{4}{*}{ Participants } & \multirow{4}{*}{\multicolumn{2}{|c|}{$\begin{array}{l}214 \text { patients with acute gastrointestinal bleeding and cirrhosis were randomly allocated to } 1 \text { of } 2 \\
\text { groups: } \\
\text { - } \quad \text { Liberal group: } \mathrm{n}=105 \\
\text { Restrictive group: } \mathrm{n}=109 \\
\text { NB: no demographic information was presented, although stated that baseline characteristics } \\
\text { were in the } 2 \text { groups }\end{array}$}} \\
\hline & & \\
\hline & & \\
\hline & & \\
\hline \multirow[t]{2}{*}{ Interventions } & \multirow{2}{*}{\multicolumn{2}{|c|}{$\begin{array}{l}\text { Liberal group received packed } \mathrm{RBC} \text { when } \mathrm{Hb} \text { level dropped below } 9.0 \mathrm{~g} / \mathrm{dL} \text { (to } \\
\text { maintain } \mathrm{Hb} \text { concentration at } 9.0 \text { to } 10.0 \mathrm{~g} / \mathrm{dL} \text { ) } \\
\text { Restrictive group received packed } \mathrm{RBC} \text { when } \mathrm{Hb} \text { level dropped below } 7.0 \mathrm{~g} / \mathrm{dL} \text { (to } \\
\text { maintain } \mathrm{Hb} \text { concentration at } 7.0 \text { to } 8.0 \mathrm{~g} / \mathrm{dL} \text { ) }\end{array}$}} \\
\hline & $\begin{array}{l}\text { - } \quad \text { Restrictiv } \\
\text { maintain }\end{array}$ & \\
\hline Outcomes & \multicolumn{2}{|c|}{ Outcomes reported: mortality, therapeutic failures, transfusion, $\mathrm{Hb}$ concentration, side effects } \\
\hline Notes & \multicolumn{2}{|l|}{ Conference abstract } \\
\hline \multicolumn{3}{|l|}{ Risk Of Bias } \\
\hline Bias & Author' judgement & Support for judgement \\
\hline $\begin{array}{l}\text { Random sequence } \\
\text { generation (selection } \\
\text { bias) }\end{array}$ & Unclear risk & No information \\
\hline $\begin{array}{l}\text { Allocation } \\
\text { concealment } \\
\text { (selection bias) }\end{array}$ & Unclear risk & No information \\
\hline $\begin{array}{l}\text { Blinding } \\
\text { (performance bias } \\
\text { and detection bias) } \\
\text { All outcomes }\end{array}$ & Unclear risk & No information \\
\hline $\begin{array}{l}\text { Incomplete outcome } \\
\text { data (attrition bias) } \\
\text { All outcomes }\end{array}$ & Unclear risk & $\begin{array}{l}\text { Insufficient information presented to permit } \\
\text { judgement of 'Yes' or 'No' }\end{array}$ \\
\hline $\begin{array}{l}\text { Selective reporting } \\
\text { (reporting bias) }\end{array}$ & Unclear risk & - \\
\hline Other bias & Low risk & - \\
\hline
\end{tabular}

Fortune 1987

\begin{tabular}{|c|c|}
\hline Methods & Randomised controlled trial \\
\hline \multirow[t]{3}{*}{ Participants } & $\begin{array}{l}25 \text { patients were studied prospectively following acute injury and haemorrhage. These patients } \\
\text { were randomised to } 1 \text { of } 2 \text { groups: }\end{array}$ \\
\hline & - $\quad$ Liberal group: $\mathrm{n}=13 ;$ mean age $=46.9$ years \\
\hline & - $\quad$ Restrictive group: $\mathrm{n}=12$; mean age $=46.5$ years \\
\hline \multirow[t]{3}{*}{ Interventions } & $\begin{array}{l}\text { - Liberal group had their Hct brought up to } 40 \% \text { slowly over a period of several hours by } \\
\text { the infusion of packed red cells }\end{array}$ \\
\hline & $\begin{array}{l}\text { - Restrictive group had their Hct maintained close to } 30 \% \text { by the appropriate } \\
\text { administration of packed red cells }\end{array}$ \\
\hline & $\begin{array}{l}\text { NB: all patients had sustained a Class III or Class IV haemorrhage and had clinical signs of shock } \\
\text { (systolic blood pressure }<90 \text { torr, heart rate }>100 \mathrm{bpm} \text { or urine output }<20 \mathrm{ml} / \mathrm{hr} \text { ) before entry into } \\
\text { the study. Patients were resuscitated according to the clinical protocol of the centre first using } \\
\text { crystalloid to re-establish organ perfusion and haemodynamic stability and then giving sufficient }\end{array}$ \\
\hline
\end{tabular}

Cochrane Database Syst Rev. Author manuscript; available in PMC 2014 September 23. 
packed red cells to achieve a Hct close to $30 \%$. Patients were studied twice a day for 3 days after the period of haemorrhagic shock

\begin{tabular}{|c|c|c|}
\hline Outcomes & \multicolumn{2}{|c|}{$\begin{array}{l}\text { Outcomes reported: } \mathrm{RBC} \text { consumption (units), cardiopulmonary parameters: pulmonary capillary } \\
\text { wedge pressure (PCWP), intrapulmonary shunt, tissue oxygenation/perfusion, oxygen } \\
\text { consumption/delivery, arterial and venous } \mathrm{O}_{2} \text { saturations, arterial and venous } \mathrm{O}_{2} \text { contents, cardiac } \\
\text { index (CI), heart rate, systemic vascular resistance, left ventricular stroke work index }\end{array}$} \\
\hline \multicolumn{3}{|l|}{ Notes } \\
\hline \multicolumn{3}{|l|}{ Risk Of Bias } \\
\hline Bias & Author' judgement & Support for judgement \\
\hline $\begin{array}{l}\text { Random } \\
\text { sequence } \\
\text { generation } \\
\text { (selection bias) }\end{array}$ & Unclear risk & No information \\
\hline $\begin{array}{l}\text { Allocation } \\
\text { concealment } \\
\text { (selection bias) }\end{array}$ & Unclear risk & No information \\
\hline $\begin{array}{l}\text { Blinding } \\
\text { (performance } \\
\text { bias and } \\
\text { detection bias) } \\
\text { All outcomes }\end{array}$ & Unclear risk & No information \\
\hline $\begin{array}{l}\text { Incomplete } \\
\text { outcome data } \\
\text { (attrition bias) } \\
\text { All outcomes }\end{array}$ & Low risk & Appears to have been complete \\
\hline $\begin{array}{l}\text { Selective } \\
\text { reporting } \\
\text { (reporting bias) }\end{array}$ & Unclear risk & - \\
\hline Other bias & Low risk & - \\
\hline
\end{tabular}

Foss 2009

\begin{tabular}{|c|c|c|}
\hline \multicolumn{3}{|l|}{ Methods } \\
\hline Participants & \multicolumn{2}{|c|}{$\begin{array}{l}\text { - Liberal group: } \mathrm{n}=60 ; \mathrm{M} / \mathrm{F}=14 / 46 ; \text { mean }(\mathrm{SD}) \text { age }=81(6.8) \text { years } \\
\text { - Restrictive group: } \mathrm{n}=60 ; \mathrm{M} / \mathrm{F}=14 / 46 ; \text { mean }(\mathrm{SD}) \text { age }=81(7.3) \text { years }\end{array}$} \\
\hline Interventions & \multicolumn{2}{|c|}{$\begin{array}{l}\text { - Liberal group received packed } \mathrm{RBC} \text { when } \mathrm{Hb} \text { level dropped below } 10.0 \mathrm{~g} / \mathrm{dL} \\
\text { - }\end{array}$} \\
\hline Outcomes & \multicolumn{2}{|c|}{$\begin{array}{l}\text { Outcomes reported: ambulatory capacity, mortality, length of stay, cardiac complications, } \\
\text { infectious complications }\end{array}$} \\
\hline \multicolumn{3}{|l|}{ Notes } \\
\hline \multicolumn{3}{|l|}{ Risk Of Bias } \\
\hline Bias & Author' judgement & Support for judgement \\
\hline $\begin{array}{l}\text { Random sequence } \\
\text { generation (selection } \\
\text { bias) }\end{array}$ & Low risk & Computer-generated list \\
\hline $\begin{array}{l}\text { Allocation } \\
\text { concealment } \\
\text { (selection bias) }\end{array}$ & Unclear risk & Sealed envelopes \\
\hline
\end{tabular}

Cochrane Database Syst Rev. Author manuscript; available in PMC 2014 September 23. 


\begin{tabular}{lll}
$\begin{array}{l}\text { Blinding } \\
\text { (performance bias } \\
\text { and detection bias) } \\
\text { All outcomes }\end{array}$ & Unclear risk & Reported as being double-blind \\
\hline $\begin{array}{l}\text { Incomplete outcome } \\
\text { data (attrition bias) }\end{array}$ & Low risk & Intention-to-treat analysis used \\
$\begin{array}{lll}\text { All outcomes } \\
\text { Selective reporting } \\
\text { (reporting bias) }\end{array}$ & Unclear risk & - \\
\hline Other bias & Low risk & - \\
\hline
\end{tabular}

Grover 2005

\begin{tabular}{|c|c|c|}
\hline Methods & \multicolumn{2}{|c|}{ Randomised controlled trial } \\
\hline \multirow[t]{3}{*}{ Participants } & \multicolumn{2}{|c|}{$\begin{array}{l}260 \text { patients undergoing elective lower limb joint replacement surgery were randomly allocated } \\
\text { to } 1 \text { of } 2 \text { groups: }\end{array}$} \\
\hline & \multicolumn{2}{|c|}{ - Liberal group: $\mathrm{n}=109 ; \mathrm{M} / \mathrm{F}=55 / 54 ;$ mean $(\mathrm{SD})$ age $=71.5(7.6)$ years } \\
\hline & \multicolumn{2}{|c|}{ Restrictive group: $\mathrm{n}=109 ; \mathrm{M} / \mathrm{F}=48 / 61 ;$ mean $(\mathrm{SD})$ age $=70.7(7.1)$ years } \\
\hline \multirow[t]{2}{*}{ Interventions } & \multirow{2}{*}{\multicolumn{2}{|c|}{$\begin{array}{l}\text { Liberal group received packed RBC when } \mathrm{Hb} \text { level dropped below } 10.0 \mathrm{~g} / \mathrm{dL} \text {, and } \\
\mathrm{Hb} \text { concentration maintained between } 10.0 \text { to } 12.0 \mathrm{~g} / \mathrm{dL} \\
\text { Restrictive group received packed RBC when } \mathrm{Hb} \text { level dropped below } 8.0 \mathrm{~g} / \mathrm{dL} \text { and } \\
\mathrm{Hb} \text { concentration maintained between } 8.0 \text { to } 9.5 \mathrm{~g} / \mathrm{dL}\end{array}$}} \\
\hline & & \\
\hline Outcomes & \multicolumn{2}{|c|}{$\begin{array}{l}\text { Outcomes reported: ischaemic load, blood load, Hb concentration, number of units transfused, } \\
\text { length of hospital stay, adverse events, new infections requiring antibiotic therapy }\end{array}$} \\
\hline \multicolumn{3}{|l|}{ Notes } \\
\hline \multicolumn{3}{|l|}{ Risk Of Bias } \\
\hline Bias & Author' judgement & Support for judgement \\
\hline $\begin{array}{l}\text { Random sequence } \\
\text { generation } \\
\text { (selection bias) }\end{array}$ & Low risk & Random numbers table \\
\hline $\begin{array}{l}\text { Allocation } \\
\text { concealment } \\
\text { (selection bias) }\end{array}$ & Unclear risk & Sealed envelopes \\
\hline $\begin{array}{l}\text { Blinding } \\
\text { (performance bias } \\
\text { and detection bias) } \\
\text { All outcomes }\end{array}$ & Unclear risk & $\begin{array}{l}\text { Anaesthetists and surgical team responsible for } \\
\text { treatment were aware of allocation. Outcome } \\
\text { assessment was blind }\end{array}$ \\
\hline $\begin{array}{l}\text { Incomplete } \\
\text { outcome data } \\
\text { (attrition bias) } \\
\text { All outcomes }\end{array}$ & Unclear risk & $\begin{array}{l}\text { Of a recruited } 260 \text { patients, outcome data presented } \\
\text { for } 218 \text {. Missing } 42 \text { did not have analysable tape } \\
\text { recordings }\end{array}$ \\
\hline $\begin{array}{l}\text { Selective reporting } \\
\text { (reporting bias) }\end{array}$ & Unclear risk & - \\
\hline Other bias & Low risk & - \\
\hline
\end{tabular}

Hajjar 2010 


\begin{tabular}{|c|c|c|}
\hline Methods & \multicolumn{2}{|c|}{ Randomised clinical trial } \\
\hline Participants & \multicolumn{2}{|c|}{$\begin{array}{l}502 \text { adult patients who underwent cardiac surgery with cardiopulmonary bypass } \\
\text { Liberal group: } \mathrm{n}=257 ; \mathrm{M} / \mathrm{F}=161 / 92 ; \text { mean }(\mathrm{SD}) \text { age } 60.7(12.5) \text { years } \\
\text { - Restrictive group: } \mathrm{n}=255 ; \mathrm{M} / \mathrm{F}=149 / 100 \text {; mean (SD) age } 58.6(12.5)\end{array}$} \\
\hline Interventions & \multicolumn{2}{|c|}{$\begin{array}{l}\text { Liberal group were transfused RBC if the haematocrit was less than } 30 \% \text { at any time } \\
\text { from the start of surgery until discharge from the ICU } \\
\text { Restrictive group were transfused if haematocrit values were less than } 24 \%\end{array}$} \\
\hline Outcomes & \multicolumn{2}{|c|}{$\begin{array}{l}\text { Outcomes reported: primary outcome composite endpoint that included 30-day all-cause } \\
\text { mortality and severe morbidity (cardiogenic shock, ARDS or acute renal injury requiring dialysis } \\
\text { or haemofiltration. Respiratory, cardiac, neurologic and infectious complications; inflammatory } \\
\text { complications; bleeding; ICU and hospital lengths of stay, RBC transfusions.) }\end{array}$} \\
\hline \multicolumn{3}{|l|}{ Notes } \\
\hline \multicolumn{3}{|l|}{ Risk Of Bias } \\
\hline Bias & Author' judgement & Support for judgement \\
\hline $\begin{array}{l}\text { Random } \\
\text { sequence } \\
\text { generation } \\
\text { (selection bias) }\end{array}$ & Low risk & Random-number table prepared by chief statistician \\
\hline $\begin{array}{l}\text { Allocation } \\
\text { concealment } \\
\text { (selection bias) }\end{array}$ & Unclear risk & Opaque envelopes \\
\hline $\begin{array}{l}\text { Blinding } \\
\text { (performance } \\
\text { bias and detection } \\
\text { bias) } \\
\text { All outcomes }\end{array}$ & Unclear risk & $\begin{array}{l}\text { Patient and outcome assessors were blinded; clinicians } \\
\text { were not blinded }\end{array}$ \\
\hline $\begin{array}{l}\text { Incomplete } \\
\text { outcome data } \\
\text { (attrition bias) } \\
\text { All outcomes }\end{array}$ & Low risk & Intention-to-treat. Complete follow-up. \\
\hline $\begin{array}{l}\text { Selective } \\
\text { reporting } \\
\text { (reporting bias) }\end{array}$ & Unclear risk & - \\
\hline Other bias & Low risk & - \\
\hline
\end{tabular}

Hebert 1995

\begin{tabular}{ll}
\hline Methods & Randomised controlled trial \\
\hline Participants & $\begin{array}{l}69 \text { normovolaemic critically ill patients admitted to } 1 \text { of } 5 \text { tertiary level intensive care units with } \\
\text { Hb values }<9.0 \mathrm{~g} / \mathrm{dL} \text { within } 72 \text { hours of admission were randomly assigned to } 1 \text { of } 2 \text { groups: }\end{array}$ \\
& Liberal group: $\mathrm{n}=36 ; \mathrm{M} / \mathrm{F}=19 / 17 ;$ mean $(\mathrm{SD})$ age $=59(21)$ years \\
& Restrictive group: $\mathrm{n}=33 ; \mathrm{M} / \mathrm{F}=14 / 19 ;$ mean $(\mathrm{SD})$ age $=58(15)$ years \\
\hline Interventions & $\begin{array}{l}\text { Liberal group were transfused } \mathrm{RBC} \text { if the } \mathrm{Hb} \text { level fell to between } 10.0 \text { to } 10.5 \mathrm{~g} / \mathrm{dL} . \\
\text { Hb level maintained between } 10.0 \text { to } 12.0 \mathrm{~g} / \mathrm{dL} .\end{array}$ \\
& Restrictive group were transfused $\mathrm{RBC}$ if the $\mathrm{Hb}$ level fell to between 7.0 to $7.5 \mathrm{~g} / \mathrm{dL}$. \\
& Hb level was maintained between 7.0 to $9.0 \mathrm{~g} / \mathrm{dL}$.
\end{tabular}


Outcomes

Outcomes reported: mortality, length of hospital stay, length of ICU stay, blood usage (units), complications, Hb levels

\begin{tabular}{|c|c|c|}
\hline \multicolumn{3}{|l|}{ Notes } \\
\hline \multicolumn{3}{|l|}{ Risk of bias } \\
\hline Bias & Authors' judgement & Support for judgement \\
\hline $\begin{array}{l}\text { Random sequence } \\
\text { generation } \\
\text { (selection bias) }\end{array}$ & Unclear risk & $\begin{array}{l}\text { Patients were assigned to } 1 \text { of } 2 \text { groups by consecutive } \\
\text { allocation from a random listing stratified by centre } \\
\text { and disease severity }\end{array}$ \\
\hline $\begin{array}{l}\text { Allocation } \\
\text { concealment } \\
\text { (selection bias) }\end{array}$ & Unclear risk & No information \\
\hline $\begin{array}{l}\text { Blinding } \\
\text { (performance bias } \\
\text { and detection bias } \\
\text { All outcomes }\end{array}$ & Unclear risk & "Blinding of treatment allocation was not feasible" \\
\hline $\begin{array}{l}\text { Incomplete } \\
\text { outcome data } \\
\text { (attrition bias } \\
\text { All outcomes }\end{array}$ & Low risk & Intention-to-treat analysis used \\
\hline $\begin{array}{l}\text { Selective } \\
\text { reporting } \\
\text { (reporting bias) }\end{array}$ & Low risk & - \\
\hline Other bias & Low risk & - \\
\hline
\end{tabular}

Hebert 1999

\begin{tabular}{|c|c|c|}
\hline Methods & \multicolumn{2}{|c|}{ Randomised controlled trial } \\
\hline \multirow[t]{3}{*}{ Participants } & \multicolumn{2}{|c|}{$\begin{array}{l}838 \text { critically ill patients with euvolemia after initial treatment who had } \mathrm{Hb} \text { concentrations }<9.0 \\
\text { g/dL within } 72 \text { hours after admission to the intensive care unit were randomly assigned to } 1 \text { of } 2 \\
\text { groups: }\end{array}$} \\
\hline & \multicolumn{2}{|c|}{ - Liberal group: $\mathrm{n}=420 ; \mathrm{M} / \mathrm{F}=255 / 165 ;$ mean $(\mathrm{SD})$ age $=58.1(18.3)$ years } \\
\hline & \multicolumn{2}{|c|}{ Restrictive group: $\mathrm{n}=418 ; \mathrm{M} / \mathrm{F}=269 / 149 ;$ mean $(\mathrm{SD})$ age $=57.1(18.1)$ years } \\
\hline \multirow[t]{2}{*}{ Interventions } & \multirow{2}{*}{\multicolumn{2}{|c|}{$\begin{array}{l}\text { Liberal group were transfused } \mathrm{RBC} \text { when the } \mathrm{Hb} \text { concentration fell below } 10.0 \mathrm{~g} / \mathrm{dL} \text {. } \\
\text { The Hb concentration was maintained between } 10.0 \text { to } 12.0 \mathrm{~g} / \mathrm{dL} \text {. } \\
\text { Restrictive group were transfused } \mathrm{RBC} \text { if the Hb concentration dropped below } 7.0 \\
\mathrm{~g} / \mathrm{dL} \text {. The Hb concentration was maintained between } 7.0 \text { to } 9.0 \mathrm{~g} / \mathrm{dL} \text {. }\end{array}$}} \\
\hline & & \\
\hline Outcomes & \multicolumn{2}{|c|}{$\begin{array}{l}\text { Outcomes reported: mortality, length of hospital stay, length of ICU stay, blood usage (units), } \\
\text { complications, infection rates, cardiac events, pulmonary oedema, pneumonia }\end{array}$} \\
\hline \multicolumn{3}{|l|}{ Notes } \\
\hline \multicolumn{3}{|l|}{ Risk of bias } \\
\hline Bias & \multicolumn{2}{|c|}{ Authors' judgement Support for judgement } \\
\hline $\begin{array}{l}\text { Random sequence } \\
\text { generation } \\
\text { (selection bias) }\end{array}$ & \multicolumn{2}{|r|}{ Computer-generated random order } \\
\hline $\begin{array}{l}\text { Allocation } \\
\text { concealment } \\
\text { (selection bias) }\end{array}$ & Unclear risk & $\begin{array}{l}\text { Sealed, opaque envelopes prepared by the data-coordinating centre and } \\
\text { distributed to each participating institution where they were opened up } \\
\text { sequentially to determine the patients treatment assignment. The } \\
\text { envelopes were returned periodically to the co-ordinating centre for } \\
\text { auditing }\end{array}$ \\
\hline
\end{tabular}




\begin{tabular}{|c|c|c|}
\hline $\begin{array}{l}\text { Blinding } \\
\text { (performance bias } \\
\text { and detection bias) } \\
\text { All outcomes }\end{array}$ & Unclear risk & $\begin{array}{l}\text { "It was not feasible to mask the assigned transfusion strategy from } \\
\text { health care providers" }\end{array}$ \\
\hline $\begin{array}{l}\text { Incomplete } \\
\text { outcome data } \\
\text { (attrition bias) } \\
\text { All outcomes }\end{array}$ & Low risk & Intention-to-treat analysis used \\
\hline $\begin{array}{l}\text { Selective reporting } \\
\text { (reporting bias) }\end{array}$ & Low risk & - \\
\hline Other bias & Low risk & - \\
\hline
\end{tabular}

Johnson 1992

\begin{tabular}{|c|c|c|}
\hline Methods & \multicolumn{2}{|c|}{ Randomised controlled trial } \\
\hline Participants & \multicolumn{2}{|c|}{$\begin{array}{l}39 \text { autologous blood donors undergoing elective myocardial revascularisation were } \\
1 \text { of } 2 \text { groups: } \\
\qquad \quad \text { Liberal group: } \mathrm{n}=18 ; \mathrm{M} / \mathrm{F}=16 / 2 ; \text { mean }(\mathrm{SD}) \text { age }=60.5(6.9) \text { years } \\
\text { - Restrictive group: } \mathrm{n}=20 ; \mathrm{M}=20 ; \text { mean }(\mathrm{SD}) \text { age }=58.2(7.5) \text { years }\end{array}$} \\
\hline Interventions & \multicolumn{2}{|c|}{$\begin{array}{l}\text { NB: operative management included sequestration of } 1 \text { or more units of fresh autologous blood in } \\
\text { patients with a Hct value greater than } 35 \% \text { who were haemodynamically stable after anaesthetic } \\
\text { induction. Red cell conservation was practised through salvage of oxygenator contents and } \\
\text { reinfusion of postoperatively shed mediastinal blood. On the } 5 \text { th postoperative day all patients were } \\
\text { asked to complete an exercise treadmill test. A second test was performed the following day }\end{array}$} \\
\hline Outcomes & \multicolumn{2}{|c|}{$\begin{array}{l}\text { Outcomes reported: cardiac events, complications, postoperative blood loss, blood use (total } \\
\text { units), allogeneic blood use (units), autologous blood use (units), all product blood use (units), } \\
\text { number of patients receiving transfusions, mean cardiac index, mean systemic resistance, exercise } \\
\text { capacity, Hct levels, length of ICU stay, length of hospital stay }\end{array}$} \\
\hline \multicolumn{3}{|l|}{ Notes } \\
\hline \multicolumn{3}{|l|}{ Risk of bias } \\
\hline Bias & Authors' judgement & Support for judgement \\
\hline $\begin{array}{l}\text { Random } \\
\text { sequence } \\
\text { generation } \\
\text { (selection bias) }\end{array}$ & Unclear risk & $\begin{array}{l}\text { Randomised with the aid of a table of random } \\
\text { numbers and an odd-even designation }\end{array}$ \\
\hline $\begin{array}{l}\text { Allocation } \\
\text { concealment } \\
\text { (selection bias) }\end{array}$ & High risk & Inadequately concealed \\
\hline $\begin{array}{l}\text { Blinding } \\
\text { (performance } \\
\text { bias and } \\
\text { detection bias) } \\
\text { All outcomes }\end{array}$ & Unclear risk & $\begin{array}{l}\text { Surgeons and anaesthesiologists were blinded as to } \\
\text { the group of randomisation until the patient reached } \\
\text { the intensive care unit (ICU) }\end{array}$ \\
\hline $\begin{array}{l}\text { Incomplete } \\
\text { outcome data } \\
\text { (attrition bias) } \\
\text { All outcomes }\end{array}$ & Unclear risk & A small number of exclusions were reported \\
\hline $\begin{array}{l}\text { Selective } \\
\text { reporting } \\
\text { (reporting bias) }\end{array}$ & Unclear risk & - \\
\hline
\end{tabular}


Lacroix 2007

\begin{tabular}{|c|c|c|}
\hline Methods & \multicolumn{2}{|c|}{ Randomised controlled trial } \\
\hline Participants & \multicolumn{2}{|c|}{$\begin{array}{l}637 \text { stable, critically ill children with Hb concentrations below } 9.5 \mathrm{~g} / \mathrm{dL} \text { within } 7 \text { days after } \\
\text { admission to an ICU were randomly allocated to } 1 \text { of } 2 \text { groups: }\end{array}$} \\
\hline & \multirow{2}{*}{\multicolumn{2}{|c|}{$\begin{array}{l}\text { - Liberal group: } \mathrm{n}=317 ; \mathrm{M} / \mathrm{F}=191 / 126 ; \text { mean }(\mathrm{SD}) \text { age }=39.6(51.9) \text { months } \\
\text { - Restrictive group: } \mathrm{n}=320 ; \mathrm{M} / \mathrm{F}=190 / 130 ; \text { mean }(\mathrm{SD}) \text { age }=35.8(46.2) \text { months }\end{array}$}} \\
\hline & & \\
\hline \multirow[t]{2}{*}{ Interventions } & $\begin{array}{l}\text { - Liberal grc } \\
\text { g/dL, with }\end{array}$ & $\begin{array}{l}\text { lp were transfused } \mathrm{RBC} \text { when the } \mathrm{Hb} \text { concentration fell below } 9.5 \\
\text { target range of } 11.0 \text { to } 12.0 \mathrm{~g} / \mathrm{dL}\end{array}$ \\
\hline & $\begin{array}{l}\text { - } \quad \text { Restrictive } \\
\text { g/dL, with }\end{array}$ & $\begin{array}{l}\text { group were transfused } \mathrm{RBC} \text { ifthe } \mathrm{Hb} \text { concentration dropped below } 7.0 \\
\text { target range of } 8.5 \text { to } 9.5 \mathrm{~g} / \mathrm{dL}\end{array}$ \\
\hline Outcomes & \multicolumn{2}{|c|}{ Outcomes reported: 28-day mortality, sepsis, transfusion reactions, infections, length of stay } \\
\hline \multicolumn{3}{|l|}{ Notes } \\
\hline \multicolumn{3}{|l|}{ Risk of bias } \\
\hline Bias & Authors' judgement & Support for judgement \\
\hline $\begin{array}{l}\text { Random sequence } \\
\text { generation (selection } \\
\text { bias) }\end{array}$ & Unclear risk & No information \\
\hline $\begin{array}{l}\text { Allocation } \\
\text { concealment } \\
\text { (selection bias) }\end{array}$ & Low risk & Internet-based, central allocation \\
\hline $\begin{array}{l}\text { Blinding } \\
\text { (performance bias } \\
\text { and detection bias) } \\
\text { All outcomes }\end{array}$ & Unclear risk & $\begin{array}{l}\text { Clinical staff and parents of the patients were aware of the } \\
\text { assignments to study groups, but the statistician and members of the } \\
\text { data and safety monitoring committee were unaware of the } \\
\text { assignments }\end{array}$ \\
\hline $\begin{array}{l}\text { Incomplete outcome } \\
\text { data (attrition bias) } \\
\text { All outcomes }\end{array}$ & Low risk & Intention-to-treat analysis used \\
\hline $\begin{array}{l}\text { Selective reporting } \\
\text { (reporting bias) }\end{array}$ & Low risk & - \\
\hline Other bias & Low risk & - \\
\hline
\end{tabular}

Lotke 1999

\begin{tabular}{ll}
\hline Methods & Randomised controlled trial \\
\hline Participants & $\begin{array}{l}\text { 152 patients undergoing primary total knee arthroplasty (TKA) were randomly assigned to } 1 \text { of } \\
\text { 2 groups: }\end{array}$ \\
$\qquad \quad$ Liberal group: $\mathrm{n}=65 ; \mathrm{M} / \mathrm{F}=19 / 46 ;$ mean age $=69.7$ years \\
Restrictive group: $\mathrm{n}=62 ; \mathrm{M} / \mathrm{F}=20 / 42 ;$ mean age $=68.7$ years \\
\hline Interventions & $-\quad \begin{array}{l}\text { Liberal group were transfused autologous blood immediately after TKA, beginning } \\
\text { in the recovery room postoperatively }\end{array}$
\end{tabular}


- $\quad$ Restrictive group were transfused autologous blood when the $\mathrm{Hb}$ level had fallen to $<9.0 \mathrm{~g} / \mathrm{dL}$

\begin{tabular}{|c|c|c|}
\hline Outcomes & \multicolumn{2}{|c|}{$\begin{array}{l}\text { Outcomes reported: complications, cardiac events, } \mathrm{Hb} \text { levels, blood usage (units), mental } \\
\text { confusion, lethargy, orthostatic hypotension, number of patients transfused }\end{array}$} \\
\hline \multicolumn{3}{|l|}{ Notes } \\
\hline \multicolumn{3}{|l|}{ Risk of bias } \\
\hline Bias & Authors' judgement & Support for judgement \\
\hline $\begin{array}{l}\text { Random sequence } \\
\text { generation } \\
\text { (selection bias) }\end{array}$ & Low risk & Computer random number generator \\
\hline $\begin{array}{l}\text { Allocation } \\
\text { concealment } \\
\text { (selection bias) }\end{array}$ & Unclear risk & Not reported \\
\hline $\begin{array}{l}\text { Blinding } \\
\text { (performance bias } \\
\text { and detection bias) } \\
\text { All outcomes }\end{array}$ & Unclear risk & $\begin{array}{l}\text { Assessments were made by a person blind to the } \\
\text { group to which the patient was assigned }\end{array}$ \\
\hline $\begin{array}{l}\text { Incomplete outcome } \\
\text { data (attrition bias) } \\
\text { All outcomes }\end{array}$ & Unclear risk & Appears to have been complete \\
\hline $\begin{array}{l}\text { Selective reporting } \\
\text { (reporting bias) }\end{array}$ & Unclear risk & - \\
\hline Other bias & Low risk & - \\
\hline
\end{tabular}

So-Osman 2010

\begin{tabular}{|c|c|c|}
\hline Methods & \multicolumn{2}{|c|}{ Randomised controlled trial } \\
\hline \multirow[t]{3}{*}{ Participants } & \multicolumn{2}{|c|}{$\begin{array}{l}619 \text {, patients undergoing elective orthopaedic hip/knee replacement surgery were } \\
\text { randomised to } 1 \text { of } 2 \text { wo groups: }\end{array}$} \\
\hline & \multicolumn{2}{|c|}{$\begin{array}{l}\text { Liberal (standard care) group: } \mathrm{n}=304 ; \mathrm{M} / \mathrm{F}=118 / 186 ; \text { mean }(\mathrm{SD}) \text { age }=70.3 \\
\text { (9.7) years }\end{array}$} \\
\hline & \multicolumn{2}{|c|}{$\begin{array}{l}\text { - } \quad \text { Restrictive (new transfusion policy) group: } \mathrm{n}=299 ; \mathrm{M} / \mathrm{F}=84 / 215 ; \text { mean }(\mathrm{SD}) \\
\text { age }=70.7(10.2 \text { ) years }\end{array}$} \\
\hline Interventions & \multirow{2}{*}{\multicolumn{2}{|c|}{$\begin{array}{l}\text { Liberal group received standard care } \\
\text { Restrictive group were treated using a 'new transfusion policy' }\end{array}$}} \\
\hline & & \\
\hline Outcomes & \multicolumn{2}{|c|}{$\begin{array}{l}\text { Outcomes reported: red blood cell usage, length of hospital stay, } \mathrm{Hb} \text { levels, mobilisation } \\
\text { delay, postoperative complications }\end{array}$} \\
\hline \multicolumn{3}{|l|}{ Notes } \\
\hline \multicolumn{3}{|l|}{ Risk of bias } \\
\hline Bias & Authors' judgement & Support for judgement \\
\hline $\begin{array}{l}\text { Random sequence } \\
\text { generation (selection } \\
\text { bias) }\end{array}$ & Unclear risk & No information \\
\hline $\begin{array}{l}\text { Allocation concealment } \\
\text { (selection bias) }\end{array}$ & Unclear risk & Sealed opaque envelopes \\
\hline $\begin{array}{l}\text { Blinding (performance } \\
\text { bias and detection bias) } \\
\text { All outcomes }\end{array}$ & Unclear risk & $\begin{array}{l}\text { Clinicians caring for the patients were aware of allocation status, } \\
\text { however, the study investigators were not }\end{array}$ \\
\hline
\end{tabular}

Cochrane Database Syst Rev. Author manuscript; available in PMC 2014 September 23. 


\begin{tabular}{lll}
$\begin{array}{l}\text { Incomplete outcome data } \\
\text { (attrition bias) } \\
\text { All outcomes }\end{array}$ & Unclear risk & $\begin{array}{l}\text { Intention-to-treat analysis was not performed, although unclear if } \\
\text { this would have biased the results }\end{array}$ \\
\hline $\begin{array}{l}\text { Selective reporting } \\
\text { (reporting bias) }\end{array}$ & Unclear risk & - \\
\hline Other bias & Low risk & - \\
\hline
\end{tabular}

Topley 1956

\begin{tabular}{|c|c|c|}
\hline Methods & \multicolumn{2}{|c|}{ Randomised controlled trial } \\
\hline Participants & \multicolumn{2}{|c|}{$\begin{array}{l}22 \text { trauma patients were randomly allocated to } 1 \text { of } 2 \text { groups: } \\
\text { - Liberal group: } \mathrm{n}=10\end{array}$} \\
\hline & \multicolumn{2}{|c|}{ NB: no demographic data were reported } \\
\hline Interventions & $\begin{array}{l}\text { Liberal grc } \\
\text { the end of } \\
\text { - } \quad \text { Restrictive } \\
\text { of resuscit }\end{array}$ & $\begin{array}{l}\text { ip: the aim was to achieve } 100 \% \text { or more of the red cell volume at } \\
\text { esuscitation } \\
\text { group: an attempt was made to leave the red cell volume at the end } \\
\text { ion at } 70 \% \text { to } 80 \% \text { of normal }\end{array}$ \\
\hline Outcomes & \multicolumn{2}{|c|}{$\begin{array}{l}\text { Outcomes reported: blood usage (units), blood loss, wound healing, elevated temperature, } \\
\text { number of patients transfused, Hb levels }\end{array}$} \\
\hline \multicolumn{3}{|l|}{ Notes } \\
\hline \multicolumn{3}{|l|}{ Risk of bias } \\
\hline Bias & Authors' judgement & Support for judgement \\
\hline $\begin{array}{l}\text { Random sequence } \\
\text { generation (selection } \\
\text { bias) }\end{array}$ & Unclear risk & $\begin{array}{l}\text { When the patient was considered eligible for the trial, they were } \\
\text { placed in a severity grade and an envelope opened to decide which } \\
\text { transfusion schedule was to be used }\end{array}$ \\
\hline $\begin{array}{l}\text { Allocation concealment } \\
\text { (selection bias) }\end{array}$ & Unclear risk & Sealed envelopes \\
\hline $\begin{array}{l}\text { Blinding (performance } \\
\text { bias and detection bias) } \\
\text { All outcomes }\end{array}$ & Unclear risk & No information \\
\hline $\begin{array}{l}\text { Incomplete outcome } \\
\text { data (attrition bias) } \\
\text { All outcomes }\end{array}$ & Low risk & Appears to be complete \\
\hline $\begin{array}{l}\text { Selective reporting } \\
\text { (reporting bias) }\end{array}$ & Unclear risk & - \\
\hline Other bias & Low risk & - \\
\hline
\end{tabular}

Webert 2008

\begin{tabular}{ll}
\hline Methods & Randomised controlled trial \\
\hline Participants & 60 adult patients with acute leukaemia were randomly allocated to 1 of 2 groups: \\
& Liberal group: $\mathrm{n}=31 ; \mathrm{M} / \mathrm{F}=14 / 17 ;$ mean $(\mathrm{SD})$ age $=45.3(16.8)$ years \\
& Restrictive group: $\mathrm{n}=29 ; \mathrm{M} / \mathrm{F}=1811 ;$ mean $(\mathrm{SD})$ age $=50.8(15.3)$ years \\
\hline
\end{tabular}


Interventions
- Liberal group were transfused 2 units of $\mathrm{RBC}$ when the $\mathrm{Hb}$ concentration fell below $12.0 \mathrm{~g} / \mathrm{dL}$

- $\quad$ Restrictive group were transfused 2 units of $\mathrm{RBC}$ if the Hb concentration dropped below $8.0 \mathrm{~g} / \mathrm{dL}$, with a target range of 85 to $95 \mathrm{~g} / \mathrm{dL}$

\begin{tabular}{|c|c|c|}
\hline Outcomes & \multicolumn{2}{|c|}{ Outcomes reported: transfusions, bleeding risk } \\
\hline \multicolumn{3}{|l|}{ Notes } \\
\hline \multicolumn{3}{|l|}{ Risk of bias } \\
\hline Bias & Authors' judgement & Support for judgement \\
\hline $\begin{array}{l}\text { Random sequence } \\
\text { generation } \\
\text { (selection bias) }\end{array}$ & Low risk & Computer-generated sequence generation \\
\hline $\begin{array}{l}\text { Allocation } \\
\text { concealment } \\
\text { (selection bias) }\end{array}$ & Low risk & Internet-based, central allocation \\
\hline $\begin{array}{l}\text { Blinding } \\
\text { (performance bias } \\
\text { and detection } \\
\text { bias) } \\
\text { All outcomes }\end{array}$ & Unclear risk & "Single-blinded" - blind outcome assessment \\
\hline $\begin{array}{l}\text { Incomplete } \\
\text { outcome data } \\
\text { (attrition bias) } \\
\text { All outcomes }\end{array}$ & Low risk & No missing data \\
\hline $\begin{array}{l}\text { Selective } \\
\text { reporting } \\
\text { (reporting bias) }\end{array}$ & Unclear risk & - \\
\hline Other bias & Low risk & - \\
\hline
\end{tabular}

Zygun 2009

\begin{tabular}{|c|c|}
\hline Methods & Randomised controlled trial \\
\hline \multirow[t]{2}{*}{ Participants } & $\begin{array}{l}30 \text { patients with severe traumatic brain injury were randomly allocated to } 1 \text { of } 3 \text { groups: } \\
\text { - Liberal group } 1: \mathrm{n}=10 \\
\text { - Liberal group } 2: \mathrm{n}=10 \\
\text { - } \quad \text { Restrictive group: } \mathrm{n}=10\end{array}$ \\
\hline & NB: Mean $(\mathrm{SD})$ age $=39(15)$ years, $70 \%$ of trial participants were male \\
\hline \multirow[t]{3}{*}{ Interventions } & $\begin{array}{l}\text { - Liberal group } 1 \text { were transfused } 2 \text { units of } \mathrm{RBC} \text { when the } \mathrm{Hb} \text { concentration fell below } \\
9.0 \mathrm{~g} / \mathrm{dL}\end{array}$ \\
\hline & $\begin{array}{l}\text { - Liberal group } 2 \text { were transfused } 2 \text { units of } \mathrm{RBC} \text { when the } \mathrm{Hb} \text { concentration fell below } \\
10.0 \mathrm{~g} / \mathrm{dL}\end{array}$ \\
\hline & $\begin{array}{l}\text { - Restrictive group were transfused } 2 \text { units of } \mathrm{RBC} \text { if the } \mathrm{Hb} \text { concentration dropped } \\
\text { below } 8.0 \mathrm{~g} / \mathrm{dL}\end{array}$ \\
\hline Outcomes & Outcomes reported: change in brain tissue oxygen, brain $\mathrm{pH}$, mortality \\
\hline Notes & $\begin{array}{l}\text { Additional data were obtained from lead trialist for inclusion in the meta-analysis. Data from } \\
\text { liberal groups } 1 \text { and } 2 \text { combined for analysis }\end{array}$ \\
\hline \multicolumn{2}{|l|}{ Risk of bias } \\
\hline Bias & Support for judgement \\
\hline
\end{tabular}




\begin{tabular}{|c|c|c|}
\hline $\begin{array}{l}\text { Random sequence } \\
\text { generation } \\
\text { (selection bias) }\end{array}$ & Low risk & Computer random number generator \\
\hline $\begin{array}{l}\text { Allocation } \\
\text { concealment } \\
\text { (selection bias) }\end{array}$ & Unclear risk & No information \\
\hline $\begin{array}{l}\text { Blinding } \\
\text { (performance bias } \\
\text { and detection bias) } \\
\text { All outcomes }\end{array}$ & Unclear risk & No information \\
\hline $\begin{array}{l}\text { Incomplete } \\
\text { outcome data } \\
\text { (attrition bias) } \\
\text { All outcomes }\end{array}$ & Low risk & No missing data \\
\hline $\begin{array}{l}\text { Selective reporting } \\
\text { (reporting bias) }\end{array}$ & Unclear risk & - \\
\hline Other bias & Low risk & - \\
\hline \multicolumn{3}{|l|}{$\mathrm{Hb}=$ haemoglobin } \\
\hline \multicolumn{3}{|l|}{ Hct $=$ haematocrit } \\
\hline \multicolumn{3}{|c|}{ ICU $=$ intensive care unit } \\
\hline \multicolumn{3}{|c|}{$\mathrm{PCWP}=$ pulmonary capillary wedge pressure } \\
\hline $\mathrm{RBC}=$ red blood cell & & \\
\hline
\end{tabular}

\section{Characteristics of excluded studies [ordered by study ID]}

\begin{tabular}{ll}
\hline Study & Reason for exclusion \\
\hline Vichinsky 1995 & Intervention not relevant \\
\hline
\end{tabular}

\section{Characteristics of studies awaiting assessment [ordered by study ID]}

Cooper 2011

\begin{tabular}{ll}
\hline Methods & Randomised clinical trial \\
\hline Participants & $\begin{array}{l}\text { Patients with acute myocardial infarction and haematocrit less than } 30 \% \\
\text { Sample size = 45 patients }\end{array}$ \\
\hline Interventions & $\begin{array}{l}\text { Liberal transfusion: transfuse when haematocrit }<30 \% \text { to maintain } 30 \% \text { to } 33 \%) \\
\text { Conservative transfusion: transfuse when haematocrit < 24\% to maintain 24\% to 27\% }\end{array}$ \\
\hline Outcomes & $\begin{array}{l}\text { The primary clinical safety measurement of in-hospital death, recurrent myocardial infarction, or new } \\
\text { or worsening congestive heart failure }\end{array}$ \\
\hline Notes & \\
\hline
\end{tabular}

\section{Characteristics of ongoing studies [ordered by study ID]}

MINT 


\begin{tabular}{ll}
\hline Trial name or title & Myocardial ischemia and transfusion \\
\hline Methods & Randomised, single-blinded, parallel trial \\
\hline Participants & $\begin{array}{l}\text { Anaemic patients with acute coronary syndrome, aged } 18 \text { years or over } \\
\text { Sample size }=110\end{array}$ \\
\hline Interventions & $\begin{array}{l}\text { Liberal group - receive } 1 \text { unit of packed RBC following randomisation and received } \\
\text { enough blood to raise Hb concentration above } 10 \text { g/dL, during hospitalisation for up } \\
\text { to 30 days }\end{array}$ \\
& $\begin{array}{l}\text { Restrictive group - receive transfusion if develop symptoms of anaemia or if Hb falls } \\
\text { below 8.0 g/dL }\end{array}$ \\
\hline Outcomes & $\begin{array}{l}\text { Trial performance and feasibility, Hb concentration, mortality or myocardial ischaemia, } \\
\text { unscheduled hospital admission, stroke, congestive hear failure, stent thrombosis, deep vein } \\
\text { thrombosis, pulmonary embolism, pneumonia, blood stream infection }\end{array}$ \\
\hline Starting date & September 2009 \\
\hline Contact information & \begin{tabular}{l} 
Jeffrey Carson (carson @ umdnj.edu) \\
\hline Notes
\end{tabular} \\
\hline
\end{tabular}

\section{TITRe 2}

\begin{tabular}{ll}
\hline Trial name or title & $\begin{array}{l}\text { A multi-centre randomised controlled trial of Transfusion Indication Threshold Reduction on } \\
\text { transfusion rates, morbidity and healthcare resources use following cardiac surgery }\end{array}$ \\
\hline Methods & Multicentre randomised controlled trial \\
\hline Participants & Patients aged 16 years and over undergoing cardiac surgery \\
\hline Interventions & $\begin{array}{l}\text { Liberal group - receive packed RBC if Hb concentration falls below } 9 \mathrm{~g} / \mathrm{dL}, \\
\text { objective is to maintain Hb above } 9 \mathrm{~g} / \mathrm{dL}\end{array}$ \\
$\begin{array}{l}\text { Restrictive group - receive packed RBC if Hb concentration falls below 7.5 g/dL, } \\
\text { objective is to maintain Hb above } 7.5 \mathrm{~g} / \mathrm{dL}\end{array}$ \\
\hline Outcomes
\end{tabular}

$\mathrm{Hb}=$ haemoglobin

$\mathrm{RBC}=$ red blood cells

\section{DATA AND ANALYSES}

\section{Comparison 1}

\section{Blood transfusions}

\begin{tabular}{lcclc}
\hline Outcome or subgroup title & No. of studies & No. of participants & Statistical method & Effect size \\
\hline $\begin{array}{l}\text { 1 Patients exposed to blood } \\
\text { transfusion (all studies) }\end{array}$ & 17 & 6125 & $\begin{array}{l}\text { Risk Ratio (M-H, } \\
\text { Random, 95\% CI) }\end{array}$ & $0.61[0.52,0.72]$ \\
$\begin{array}{l}2 \text { Patients exposed to } \\
\text { allogeneic blood transfusion }\end{array}$ & 10 & 4146 & $\begin{array}{l}\text { Risk Ratio (M-H, } \\
\text { Random, 95\% CI) }\end{array}$ & $0.58[0.46,0.72]$
\end{tabular}

Cochrane Database Syst Rev. Author manuscript; available in PMC 2014 September 23. 


\begin{tabular}{|c|c|c|c|c|}
\hline Outcome or subgroup title & No. of studies & No. of participants & Statistical method & Effect size \\
\hline $\begin{array}{l}3 \text { Patients exposed to } \\
\text { autologous blood transfusion }\end{array}$ & 2 & 165 & $\begin{array}{l}\text { Risk Ratio (M-H, } \\
\text { Random, 95\% CI) }\end{array}$ & $0.46[0.12,1.82]$ \\
\hline $\begin{array}{l}4 \text { Patients exposed to blood } \\
\text { transfusion (by clinical } \\
\text { setting) }\end{array}$ & 17 & 6127 & $\begin{array}{l}\text { Risk Ratio (M-H, } \\
\text { Random, 95\% CI) }\end{array}$ & $0.61[0.52,0.72]$ \\
\hline 4.1 Cardiac surgery & 3 & 968 & $\begin{array}{l}\text { Risk Ratio (M-H, } \\
\text { Random, 95\% CI) }\end{array}$ & $0.67[0.58,0.78]$ \\
\hline 4.2 Orthopaedic surgery & 6 & 3170 & $\begin{array}{l}\text { Risk Ratio (M-H, } \\
\text { Random, 95\% CI) }\end{array}$ & $0.53[0.37,0.75]$ \\
\hline 4.3 Vascular & 1 & 99 & $\begin{array}{l}\text { Risk Ratio (M-H, } \\
\text { Random, 95\% CI) }\end{array}$ & $0.91[0.77,1.08]$ \\
\hline $\begin{array}{l}\text { 4.4 Acute blood loss/ } \\
\text { trauma }\end{array}$ & 3 & 286 & $\begin{array}{l}\text { Risk Ratio (M-H, } \\
\text { Random, 95\% CI) }\end{array}$ & $0.52[0.30,0.89]$ \\
\hline 4.5 Cancer & 1 & 60 & $\begin{array}{l}\text { Risk Ratio (M-H, } \\
\text { Random, 95\% CI) }\end{array}$ & $0.96[0.82,1.12]$ \\
\hline 4.6 Critical care & 3 & 1544 & $\begin{array}{l}\text { Risk Ratio (M-H, } \\
\text { Random, 95\% CI) }\end{array}$ & $0.56[0.42,0.75]$ \\
\hline $\begin{array}{l}5 \text { Patients exposed to blood } \\
\text { transfusion (by transfusion } \\
\text { threshold) }\end{array}$ & 12 & & $\begin{array}{l}\text { Risk Ratio (M-H, } \\
\text { Random, 95\% CI) }\end{array}$ & Subtotals only \\
\hline 5.1 Difference $\geq 2 \mathrm{~g} / \mathrm{dL}$ & 10 & 4758 & $\begin{array}{l}\text { Risk Ratio (M-H, } \\
\text { Random, 95\% CI) }\end{array}$ & $0.60[0.49,0.72]$ \\
\hline 5.2 Difference $<2 \mathrm{~g} / \mathrm{dL}$ & 2 & 527 & $\begin{array}{l}\text { Risk Ratio (M-H, } \\
\text { Random, 95\% CI) }\end{array}$ & $0.82[0.63,1.07]$ \\
\hline $\begin{array}{l}6 \text { Patients exposed to blood } \\
\text { transfusion (by allocation } \\
\text { concealment) }\end{array}$ & 17 & & $\begin{array}{l}\text { Risk Ratio (M-H, } \\
\text { Random, 95\% CI) }\end{array}$ & Subtotals only \\
\hline 6.1 Low risk of bias & 4 & 2797 & $\begin{array}{l}\text { Risk Ratio (M-H, } \\
\text { Random, 95\% CI) }\end{array}$ & $0.55[0.37,0.80]$ \\
\hline 6.2 Unclear risk ofbias & 11 & 2862 & $\begin{array}{l}\text { Risk Ratio (M-H, } \\
\text { Random, 95\% CI) }\end{array}$ & $0.63[0.54,0.74]$ \\
\hline 6.3 High risk of bias & 2 & 466 & $\begin{array}{l}\text { Risk Ratio (M-H, } \\
\text { Random, 95\% CI) }\end{array}$ & $0.74[0.62,0.88]$ \\
\hline 7 Units of blood transfused & 8 & 2715 & $\begin{array}{l}\text { Mean Difference (IV, } \\
\text { Random, 95\% CI) }\end{array}$ & $-1.19[-1.85,-0.53]$ \\
\hline $\begin{array}{l}8 \text { Units of blood transfused } \\
\text { in those transfused }\end{array}$ & 8 & 1555 & $\begin{array}{l}\text { Mean Difference (IV, } \\
\text { Random, 95\% CI) }\end{array}$ & $-0.75[-1.30,-0.20]$ \\
\hline
\end{tabular}

Comparison 2

Haemoglobin concentration

\begin{tabular}{lcccc}
\hline Outcome or subgroup title & No. of studies & No. of participants & Statistical method & Effect size \\
\hline 1 Haemoglobin concentration & 12 & 5302 & $\begin{array}{c}\text { Mean Difference (IV, } \\
\text { Random, 95\% CI) }\end{array}$ & $-1.48[-1.92,-1.03]$ \\
\hline
\end{tabular}


Comparison 3

Mortality

\begin{tabular}{|c|c|c|c|c|}
\hline $\begin{array}{l}\text { Outcome or subgroup } \\
\text { title }\end{array}$ & No. of studies & No. of participants & Statistical method & Effect size \\
\hline $1 \leq 4$-day mortality & 2 & 821 & $\begin{array}{l}\text { Risk Ratio (M-H, Random, } \\
95 \% \text { CI) }\end{array}$ & $0.44[0.06,2.96]$ \\
\hline 2 30-day mortality & 11 & 4979 & $\begin{array}{l}\text { Risk Ratio (M-H, Random, } \\
95 \% \text { CI) }\end{array}$ & $0.85[0.70,1.03]$ \\
\hline 3 60-day mortality & 3 & 2938 & $\begin{array}{l}\text { Risk Ratio (M-H, Random, } \\
95 \% \text { CI) }\end{array}$ & $0.88[0.72,1.06]$ \\
\hline 4 120-day mortality & 1 & & $\begin{array}{l}\text { Risk Ratio (M-H, Random, } \\
95 \% \text { CI) }\end{array}$ & Subtotals only \\
\hline 5 Hospital mortality & 5 & 3411 & $\begin{array}{l}\text { Risk Ratio (M-H, Random, } \\
95 \% \text { CI) }\end{array}$ & $0.77[0.62,0.95]$ \\
\hline $6 \mathrm{ICU}$ mortality & 3 & 736 & $\begin{array}{l}\text { Risk Ratio (M-H, Random, } \\
95 \% \text { CI) }\end{array}$ & $1.15[0.59,2.23]$ \\
\hline $\begin{array}{l}7 \text { Mortality } \\
\text { (unspecified follow-up } \\
\text { period) }\end{array}$ & 1 & & $\begin{array}{l}\text { Risk Ratio (M-H, Random, } \\
95 \% \text { CI) }\end{array}$ & Subtotals only \\
\hline
\end{tabular}

Comparison 4

Length of stay

\begin{tabular}{lcccc}
\hline $\begin{array}{l}\text { Outcome or } \\
\text { subgroup title }\end{array}$ & No. of studies & No. of participants & Statistical method & Effect size \\
\hline $\begin{array}{l}1 \text { Hospital length of } \\
\text { stay }\end{array}$ & 8 & 4226 & $\begin{array}{c}\text { Mean Difference (IV, } \\
\text { Random, 95\% CI) }\end{array}$ & $0.11[-0.16,0.38]$ \\
2 ICU length of stay & 5 & 2114 & $\begin{array}{c}\text { Mean Difference (IV, } \\
\text { Random, 95\% CI) }\end{array}$ & $-0.15[-0.66,0.37]$ \\
\hline
\end{tabular}

Comparison 5

Function and fatigue

\begin{tabular}{|c|c|c|c|c|}
\hline Outcome or subgroup title & No. of studies & No. of participants & Statistical method & Effect size \\
\hline $\begin{array}{l}1 \text { Inability to walk or death } \\
\text { at } 30 \text { days }\end{array}$ & 1 & & $\begin{array}{l}\text { Risk Ratio (M-H, Random, } \\
95 \% \text { CI) }\end{array}$ & Subtotals only \\
\hline $\begin{array}{l}2 \text { Inability to walk or death } \\
\text { at } 60 \text { days }\end{array}$ & 1 & & $\begin{array}{l}\text { Risk Ratio (M-H, Random, } \\
95 \% \text { CI) }\end{array}$ & Subtotals only \\
\hline $\begin{array}{l}3 \text { Lower extremity physical } \\
\text { activities of daily living at } \\
30 \text { days }\end{array}$ & 1 & & $\begin{array}{l}\text { Mean Difference (IV, } \\
\text { Random, 95\% CI) }\end{array}$ & Subtotals only \\
\hline $\begin{array}{l}4 \text { Lower extremity physical } \\
\text { activities of daily living at } \\
60 \text { days }\end{array}$ & 1 & & $\begin{array}{l}\text { Mean Difference (IV, } \\
\text { Random, 95\% CI) }\end{array}$ & Subtotals only \\
\hline $\begin{array}{l}5 \text { Instrumental activities of } \\
\text { daily living at } 30 \text { days }\end{array}$ & 1 & & $\begin{array}{l}\text { Mean Difference (IV, } \\
\text { Random, 95\% CI) }\end{array}$ & Subtotals only \\
\hline $\begin{array}{l}6 \text { Instrumental activities of } \\
\text { daily living at } 60 \text { days }\end{array}$ & 1 & & $\begin{array}{l}\text { Mean Difference (IV, } \\
\text { Random, 95\% CI) }\end{array}$ & Subtotals only \\
\hline 7 Energy/fatigue at 30 days & 1 & & $\begin{array}{l}\text { Mean Difference (IV, } \\
\text { Random, 95\% CI) }\end{array}$ & Subtotals only \\
\hline
\end{tabular}




\begin{tabular}{lcllr}
\hline Outcome or subgroup title & No. of studies & No. of participants & Statistical method & Effect size \\
\hline 8 Energy/fatigue at 60 days & 1 & $\begin{array}{l}\text { Mean Difference (IV, } \\
\text { Random, 95\% CI) }\end{array}$ & Subtotals only \\
& & & \\
\hline
\end{tabular}

\section{comparison 6}

Adverse events

\begin{tabular}{|c|c|c|c|c|}
\hline $\begin{array}{l}\text { Outcome or subgroup } \\
\text { title }\end{array}$ & No. of studies & No. of participants & Statistical method & Effect size \\
\hline 1 Cardiac events & 7 & 4048 & $\begin{array}{l}\text { Risk Ratio (M-H, Random, } \\
95 \% \text { CI) }\end{array}$ & $0.96[0.70,1.32]$ \\
\hline 2 Myocardial infarction & 8 & 3884 & $\begin{array}{l}\text { Risk Ratio (M-H, Random, } \\
95 \% \text { CI) }\end{array}$ & $0.88[0.38,2.04]$ \\
\hline 3 Pulmonary oedema & 5 & 3649 & $\begin{array}{l}\text { Risk Ratio (M-H, Random, } \\
95 \% \text { CI) }\end{array}$ & $0.72[0.31,1.70]$ \\
\hline $\begin{array}{l}4 \text { Cerebrovascular } \\
\text { accident (CVA) - stroke }\end{array}$ & 5 & 2760 & $\begin{array}{l}\text { Risk Ratio (M-H, Random, } \\
95 \% \text { CI) }\end{array}$ & $0.84[0.47,1.49]$ \\
\hline 5 Pneumonia & 5 & 3695 & $\begin{array}{l}\text { Risk Ratio (M-H, Random, } \\
95 \% \text { CI) }\end{array}$ & $0.93[0.76,1.15]$ \\
\hline 6 Thromboembolism & 3 & 2220 & $\begin{array}{l}\text { Risk Ratio (M-H, Random, } \\
95 \% \text { CI) }\end{array}$ & $0.71[0.32,1.59]$ \\
\hline 7 Rebleeding & 2 & 552 & $\begin{array}{l}\text { Risk Ratio (M-H, Random, } \\
95 \% \text { CI) }\end{array}$ & $0.42[0.03,4.99]$ \\
\hline 8 Infection & 6 & 4306 & $\begin{array}{l}\text { Risk Ratio (M-H, Random, } \\
95 \% \text { CI) }\end{array}$ & $0.81[0.66,1.00]$ \\
\hline 9 Renal failure & 3 & 1567 & $\begin{array}{l}\text { Risk Ratio (M-H, Random, } \\
95 \% \text { CI) }\end{array}$ & $1.10[0.56,2.18]$ \\
\hline 10 Mental confusion & 2 & 247 & $\begin{array}{l}\text { Risk Ratio (M-H, Random, } \\
95 \% \text { CI) }\end{array}$ & $1.86[0.63,5.44]$ \\
\hline
\end{tabular}




\section{Analysis 1.1}

\section{Comparison 1 Blood transfusions, Outcome 1 Patients exposed to blood transfusion (all studies)}

Review: Transfusion thresholds and other strategies for guiding allogeneic red blood cell transfusion

Comparison: 1 Blood transfusions

Outcome: 1 Patients exposed to blood transfusion (all studies)

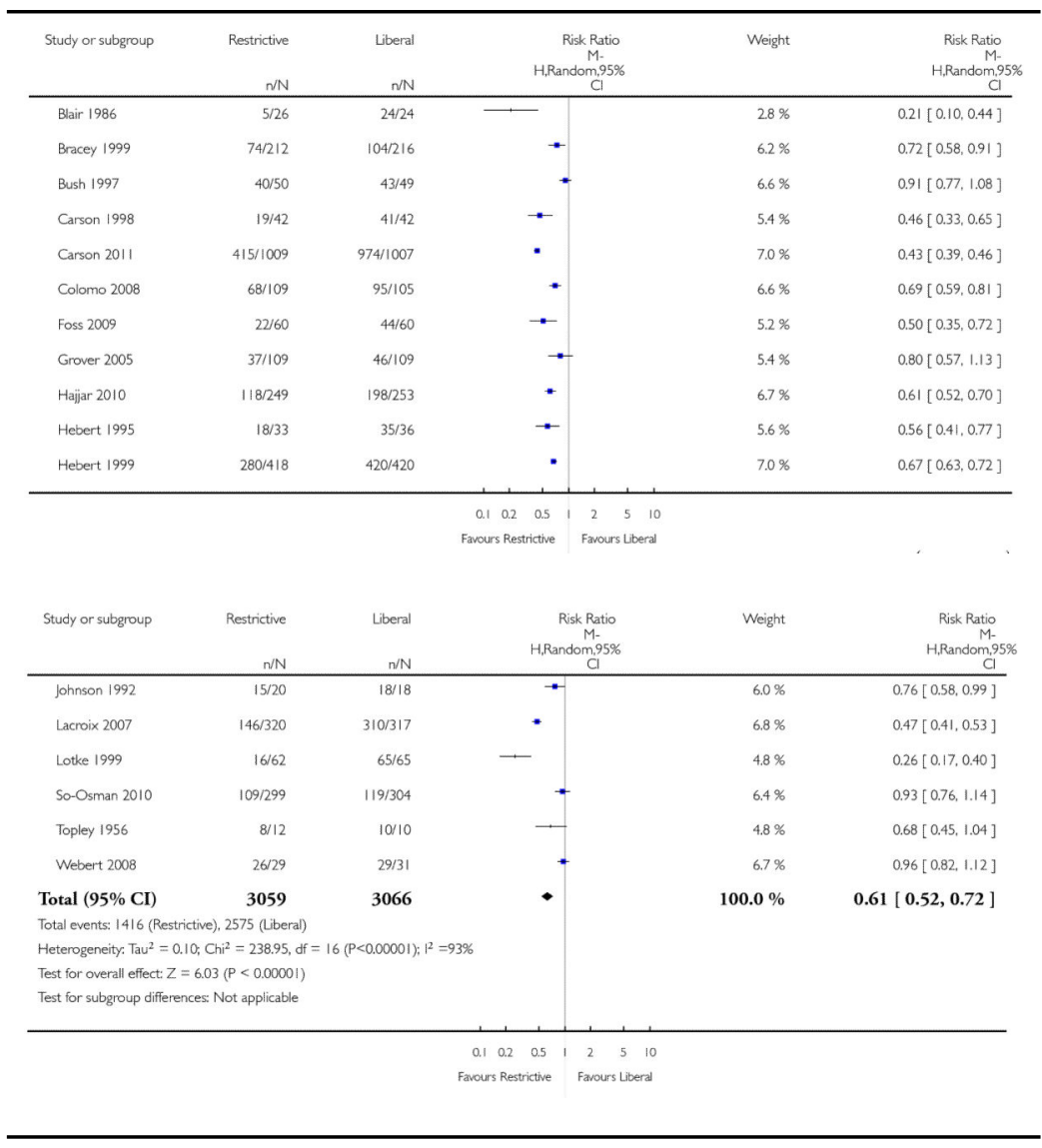




\section{Analysis 1.2}

\section{Comparison 1 Blood transfusions, Outcome 2 Patients} exposed to allogeneic blood transfusion

Review: Transfusion thresholds and other strategies for guiding allogeneic red blood cell transfusion

Comparison: 1 Blood transfusions

Outcome: 2 Patients exposed to allogeneic blood transfusion

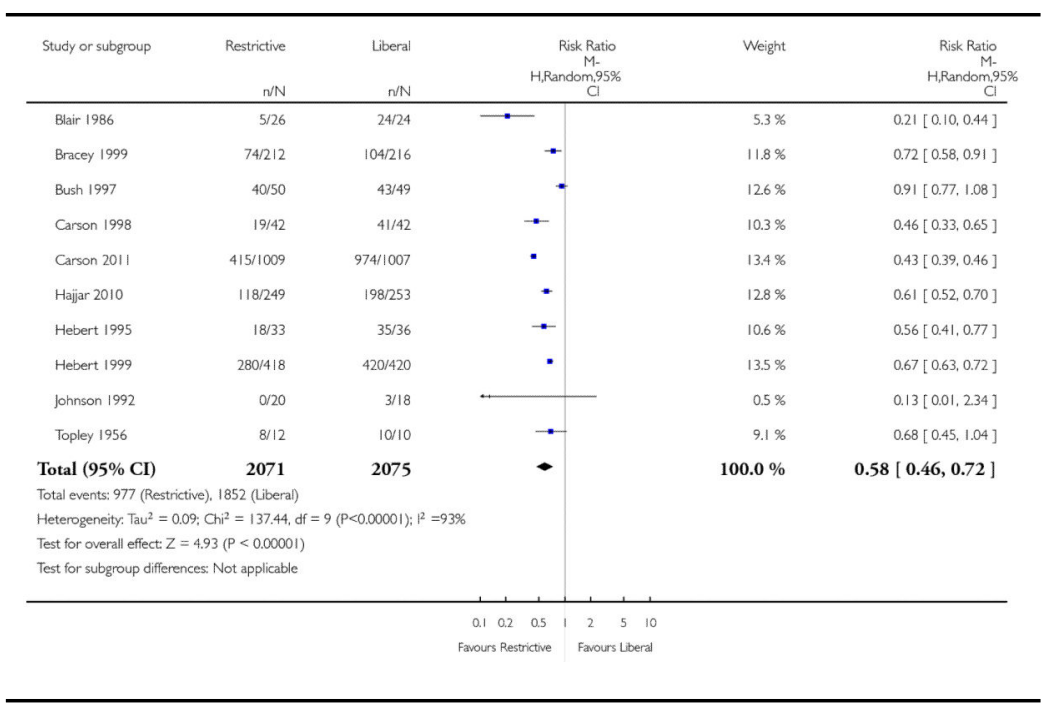

Analysis 1.3

Comparison 1 Blood transfusions, Outcome 3 Patients exposed to autologous blood transfusion

Review: Transfusion thresholds and other strategies for guiding allogeneic red blood cell transfusion

Comparison: 1 Blood transfusions

Outcome: 3 Patients exposed to autologous blood transfusion

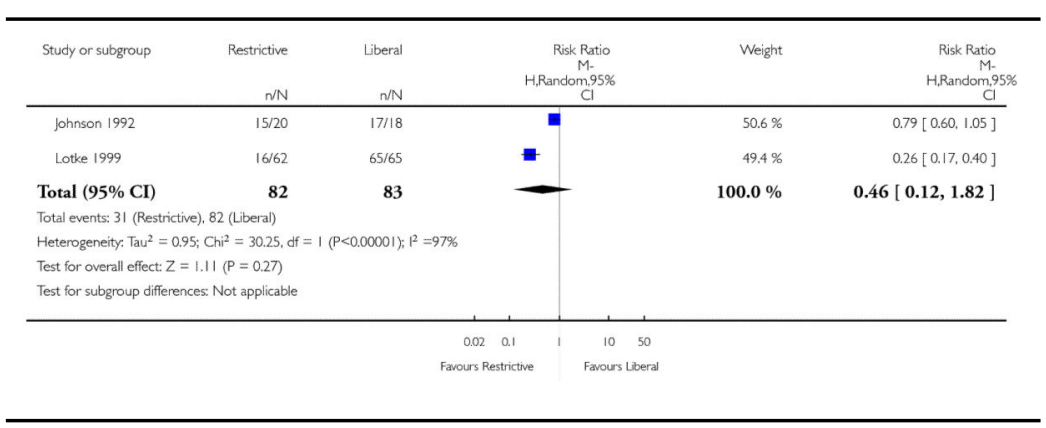




\section{Analysis 1.4}

\section{Comparison 1 Blood transfusions, Outcome 4 Patients} exposed to blood transfusion (by clinical setting)

Review: Transfusion thresholds and other strategies for guiding allogeneic red blood cell transfusion

Comparison: 1 Blood transfusions

Outcome: 4 Patients exposed to blood transfusion (by clinical setting)

\begin{tabular}{|c|c|c|c|c|c|}
\hline Study or subgroup & $\begin{array}{r}\text { Restrictive } \\
n \mathbb{N}\end{array}$ & $\begin{array}{l}\text { Liberal } \\
n / N\end{array}$ & $\begin{array}{c}\text { Risk Ratio } \\
\text { M- } \\
\text { H,Random,95\% } \\
\mathrm{Cl}\end{array}$ & Weight & $\begin{array}{c}\text { Risk Ratio } \\
\text { M. } \\
\text { H,Random,95\% } \\
\text { II }\end{array}$ \\
\hline \multicolumn{6}{|l|}{1 Cardiac surgery } \\
\hline Bracey 1999 & $74 / 212$ & $104 / 216$ & - & $6.2 \%$ & $0.72[0.58,0.91]$ \\
\hline Hajar 2010 & $118 / 249$ & 198/253 & - & $6.7 \%$ & $0.61[0.52,0.70]$ \\
\hline Johnson 1992 & $15 / 20$ & $18 / 18$ & - & $6.0 \%$ & $0.76[0.58,0.99]$ \\
\hline Subtotal $(95 \% \mathrm{CI})$ & 481 & 487 & - & $18.9 \%$ & $0.67[0.58,0.78]$ \\
\hline \multicolumn{6}{|c|}{ Total events: 207 (Restrictive), 320 (Liberal) } \\
\hline \multicolumn{6}{|c|}{ Heterogeneity; $\mathrm{Ta}^{2}=0.01 ; \mathrm{Ch}^{2}=3.03, \mathrm{df}=2(\mathrm{P}=0.22) ; \mathrm{I}^{2}=34 \%$} \\
\hline \multicolumn{6}{|c|}{ Test for overall effect $Z=5.35(P<0.00001)$} \\
\hline \multicolumn{6}{|l|}{2 Orthopaedic surgery } \\
\hline Carson 1998 & $19 / 42$ & $41 / 42$ & - & $5.4 \%$ & $0.46[0.33,0.65]$ \\
\hline Carson 2011 & $415 / 1009$ & $974 / 1009$ & * & $7.0 \%$ & $0.43[0.40,0.46]$ \\
\hline Foss 2009 & $22 / 60$ & $44 / 60$ & $\rightarrow$ & $5.2 \%$ & $0.50[0.35,0.72]$ \\
\hline Grover 2005 & $37 / 109$ & $46 / 109$ & $\rightarrow$ & $5.4 \%$ & $0.80[0.57,1.13]$ \\
\hline Lotke 1999 & $16 / 62$ & $65 / 65$ & & $4.8 \%$ & $0.26[0.17,0.40]$ \\
\hline So-Osman 2010 & 109/299 & |19/304 & $*$ & $6.4 \%$ & $0.93[0.76,1.14]$ \\
\hline Subtotal $(95 \% \mathrm{CI})$ & 1581 & 1589 & - & $34.2 \%$ & $0.53[0.37,0.75]$ \\
\hline \multicolumn{6}{|c|}{ Total events: 618 (Restrictive), 1289 (Liberal) } \\
\hline \multicolumn{6}{|c|}{ Heterogeneity: Tau $^{2}=0.17 ; \mathrm{Chi}^{2}=66.86, \mathrm{df}=5(\mathrm{P}<0.00001) ;\left.\right|^{2}=93 \%$} \\
\hline \multirow{2}{*}{\multicolumn{6}{|c|}{$\begin{array}{l}\text { Test for overall effect: } Z=3.55(P=0.00039) \\
3 \text { Vascular }\end{array}$}} \\
\hline & & & & & \\
\hline Bush 1997 & 40,50 & 43/49 & * & $6.6 \%$ & $0.91[0.77,1.08]$ \\
\hline Subtotal $(95 \% \mathrm{CI})$ & 50 & 49 & - & $6.6 \%$ & $0.91[0.77,1.08]$ \\
\hline \multicolumn{6}{|c|}{ Total events: 40 (Restrictive), 43 (Liberal) } \\
\hline \multicolumn{6}{|c|}{ Heterogeneity: not applicable } \\
\hline \multicolumn{6}{|c|}{ Test for overall effect $Z=1.04(P=0.30)$} \\
\hline \multicolumn{6}{|l|}{4 Acute blood bss/traıma } \\
\hline Blair 1986 & $5 / 26$ & $24 / 24$ & - & $28 \%$ & $0.21[0.10,0.44]$ \\
\hline Colomo 2008 & $68 / 109$ & $95 / 105$ & - & $6.6 \%$ & $0.69[0.59,0.81]$ \\
\hline Topley 1956 & $8 / 12$ & $10 / 10$ & $\rightarrow$ & $4.8 \%$ & $0.68[0.45,1.04]$ \\
\hline
\end{tabular}




\begin{tabular}{|c|c|c|c|c|c|}
\hline Study or subgroup & Restrictive & Liberal & H.Rand & Weight & $\begin{array}{c}\text { Risk Ratio } \\
\text { M- } \\
\text { H.Random,95\% } \\
\text { व }\end{array}$ \\
\hline Subtotal $(95 \% \mathrm{CI})$ & 147 & 139 & - & $14.3 \%$ & $0.52[0.30,0.89]$ \\
\hline \multicolumn{6}{|c|}{ Total events: 81 (Restrictive), 129 (Liberal) } \\
\hline \multicolumn{6}{|c|}{ Heterogeneity; Tau ${ }^{2}=0.18 ; \mathrm{Chi}^{2}=11.22, \mathrm{df}=2(P=0.004) ;\left.\right|^{2}=82 \%$} \\
\hline \multicolumn{6}{|c|}{ Test for overall effect: $Z=2.36(P=0.018)$} \\
\hline \multicolumn{6}{|l|}{5 Cancer } \\
\hline Webert 2008 & $26 / 29$ & $29 / 31$ & * & $6.7 \%$ & $0.96[0.82,1.12]$ \\
\hline Subtotal $(95 \% \mathrm{CI})$ & 29 & 31 & $\bullet$ & $6.7 \%$ & $0.96[0.82,1.12]$ \\
\hline \multicolumn{6}{|c|}{ Total events: 26 (Restrictive), 29 (Liberal) } \\
\hline \multicolumn{6}{|c|}{ Heterogeneity, not applicable } \\
\hline \multicolumn{6}{|c|}{ Test for overall effect: $Z=0.54(P=0.59)$} \\
\hline \multicolumn{6}{|l|}{6 Critical care } \\
\hline Hebert 1995 & $18 / 33$ & 35/36 & $\rightarrow$ & $5.6 \%$ & $0.56[0.41,0.77]$ \\
\hline Hebert 1999 & $280 / 418$ & $420 / 420$ & - & $7.0 \%$ & $0.67[0.63,0.72]$ \\
\hline Lacroix 2007 & 146/320 & $310 / 317$ & - & $6.8 \%$ & $0.47[0.41,0.53]$ \\
\hline Subtotal $(95 \% \mathrm{CI})$ & 771 & 773 & - & $19.4 \%$ & $0.56[0.42,0.75]$ \\
\hline \multicolumn{6}{|c|}{ Total events: 444 (Restrictive), 765 (Liberal) } \\
\hline \multicolumn{6}{|c|}{ Heterogeneity; Tau ${ }^{2}=0.06 ; \mathrm{Ch}^{2}=29.71$, of $=2(\mathrm{P}<0.00001) ; 1^{2}=93 \%$} \\
\hline \multicolumn{6}{|c|}{ Test for overall effect: $Z=3.82(P=0.00013)$} \\
\hline Total $(95 \% \mathrm{CI})$ & 3059 & 3068 & - & $100.0 \%$ & $0.61[0.52,0.72]$ \\
\hline \multicolumn{6}{|c|}{ Total events: 1416 (Restrictive), 2575 (Liberal) } \\
\hline \multicolumn{6}{|c|}{ Heterogeneity: Tau $^{2}=0.10 ; \mathrm{Ch}^{2}=237.89, \mathrm{df}=16(\mathrm{P}<0.00001) ; 1^{2}=93 \%$} \\
\hline \multicolumn{6}{|c|}{ Test for overall effect: $Z=6.04(P<0.00001)$} \\
\hline \multicolumn{6}{|c|}{ Test for subgroup differences: $\mathrm{Ch}^{2}=25.60, \mathrm{df}=5(\mathrm{P}=0.00) \cdot \mathrm{I}^{2}=80 \%$} \\
\hline & & & & & \\
\hline
\end{tabular}




\section{Analysis 1.5}

Comparison 1 Blood transfusions, Outcome 5 Patients exposed to blood transfusion (by transfusion threshold)

Review: Transfusion thresholds and other strategies for guiding allogeneic red blood cell transfusion

Comparison: 1 Blood transfusions

Outcome: 5 Patients exposed to blood transfusion (by transfusion threshold)

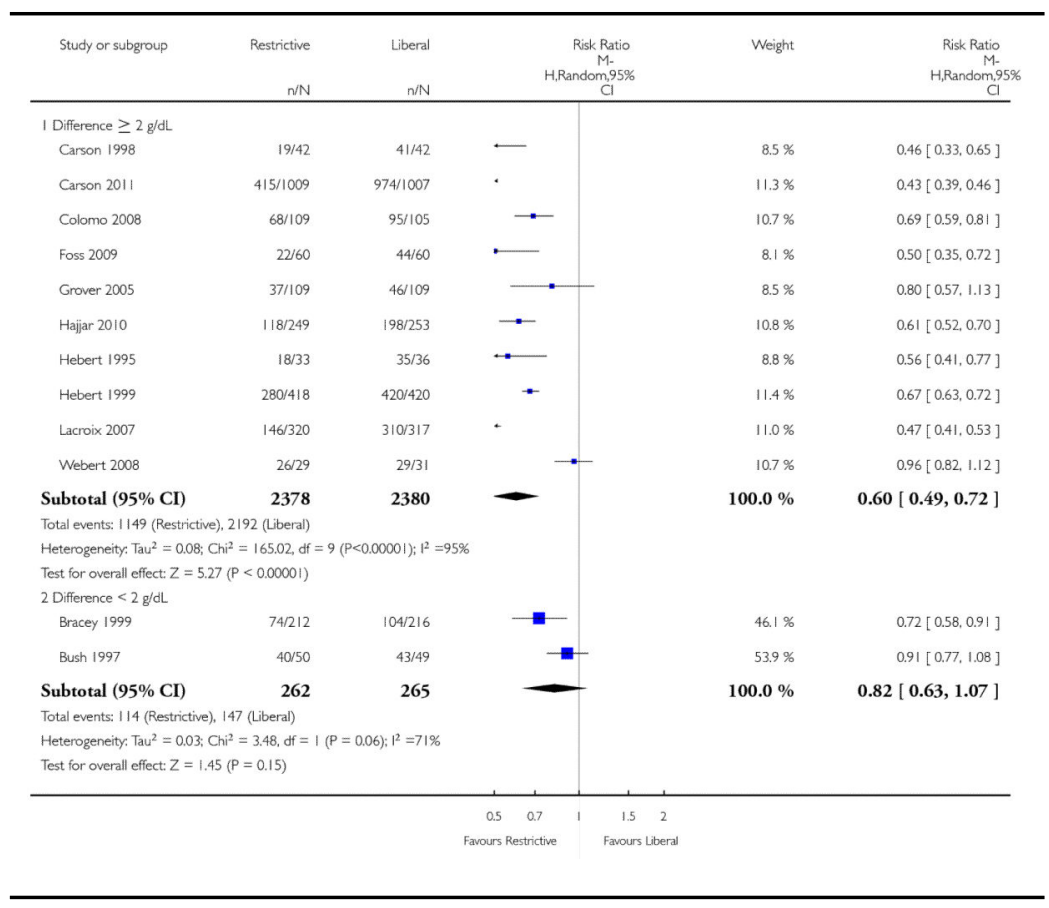




\section{Analysis 1.6}

Comparison 1 Blood transfusions, Outcome 6 Patients exposed to blood transfusion (by allocation concealment)

Review: Transfusion thresholds and other strategies for guiding allogeneic red blood cell transfusion

Comparison: 1 Blood transfusions

Outcome: 6 Patients exposed to blood transfusion (by allocation concealment)

\begin{tabular}{|c|c|c|c|c|c|}
\hline Study or subgroup & Restrictive & $\begin{array}{l}\text { Liberal } \\
n / N\end{array}$ & $\begin{array}{c}\text { Risk Ratio } \\
\text { M- } \\
\text { H.Random, } 95 \% \\
\mathrm{Cl}\end{array}$ & Weight & $\begin{array}{c}\text { Risk Ratio } \\
\text { M- } \\
\text { H,Random,95\% } \\
\text { C. }\end{array}$ \\
\hline \multicolumn{6}{|l|}{ I Low risk of bias } \\
\hline Carson 1998 & $19 / 42$ & $41 / 42$ & - & $22.1 \%$ & $0.46[0.33,0.65]$ \\
\hline Carson 2011 & $415 / 1009$ & $974 / 1007$ & - & $26.4 \%$ & $0.43[0.39,0.46]$ \\
\hline Lacroix 2007 & $146 / 320$ & $310 / 317$ & - & $26.0 \%$ & $0.47[0.41,0.53]$ \\
\hline Webert 2008 & $26 / 29$ & $29 / 31$ & . & $25.5 \%$ & $0.96[0.82,1.12]$ \\
\hline Subtotal $(95 \% \mathrm{CI})$ & 1400 & 1397 & $\longrightarrow$ & $100.0 \%$ & $0.55[0.37,0.80]$ \\
\hline \multicolumn{6}{|c|}{ Total events: 606 (Restrictive), 1354 (Liberal) } \\
\hline \multicolumn{6}{|c|}{ Heterogeneity: Ta $u^{2}=0.14 ; C \mathrm{Ch}^{2}=96.05, \mathrm{df}=3(\mathrm{p}<0.00001) ; 1^{2}=97 \%$} \\
\hline \multicolumn{6}{|c|}{ Test for overall effect: $Z=3.09(P=0.0020)$} \\
\hline \multicolumn{6}{|l|}{2 Undear risk of bias } \\
\hline Blair 1986 & 5/26 & $24 / 24$ & 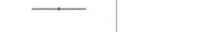 & $3.2 \%$ & $0.21[0.10 .0 .44]$ \\
\hline Bush 1997 & 40/50 & $43 / 49$ & $*$ & $11.4 \%$ & $0.91[0.77,1.08]$ \\
\hline Colomo 2008 & $68 / 109$ & $95 / 105$ & $*$ & $11.7 \%$ & $0.69[0.59,0.81]$ \\
\hline Foss 2009 & 22160 & $44 / 60$ & $\rightarrow$ & $7.6 \%$ & $0.50[0.35,0.72]$ \\
\hline Grover 2005 & $37 / 109$ & $46 / 109$ & $\rightarrow$ & $8.1 \%$ & $0.80[0.57 .1 .13]$ \\
\hline Hajar 2010 & $118 / 249$ & 198/253 & * & $11.9 \%$ & $0.61[0.52 .0 .70]$ \\
\hline Hebert 1995 & 18/33 & $35 / 36$ & $\rightarrow$ & $8.6 \%$ & $0.56[0.41,0.77]$ \\
\hline Hebert 1999 & $280 / 418$ & $420 / 420$ & " & $13.0 \%$ & $0.67[0.63,0.72]$ \\
\hline Lotke 1999 & 16162 & $65 / 65$ & $\rightarrow$ & $6.8 \%$ & $0.26[0.17,0.40]$ \\
\hline So-Osman 2010 & 109/299 & $119 / 304$ & + & $10.8 \%$ & $0.93[0.76,1.14]$ \\
\hline Topley 1956 & $8 / 12$ & $10 / 10$ & $\rightarrow$ & $6.8 \%$ & $0.68[0.45,1.04]$ \\
\hline Subtotal $(95 \% \mathrm{CI})$ & 1427 & 1435 & - & $100.0 \%$ & $0.63[0.54,0.74]$ \\
\hline \multirow{2}{*}{\multicolumn{6}{|c|}{$\begin{array}{l}\text { Total events. 721 (Restrictive), } 1099 \text { (Liberal) } \\
\text { Heterogeneity. Tau }{ }^{2}=0.05 ; \mathrm{Ch}^{2}=58.50 \text {, df }=10 \text { (P<0.00001); } 1^{2}=83 \%\end{array}$}} \\
\hline & & & & & \\
\hline \multicolumn{6}{|c|}{ Test for overall effect: $Z=5.83(P<0.00001)$} \\
\hline \multicolumn{6}{|l|}{3 High risk of bias } \\
\hline \multirow[t]{2}{*}{ Bracey 1999} & $74 / 212$ & 104/216 & $=$ & $57.1 \%$ & $0.72[0.58,0.91]$ \\
\hline & & & 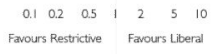 & & \\
\hline Study or subgroup & Restrictive & Liberal & $\begin{array}{c}\text { Risk Ratio } \\
M- \\
\text { H.Random.95\% } \\
\text { C. }\end{array}$ & Weight & $\begin{array}{c}\text { Risk Ratio } \\
\text { M- } \\
\text { H.Random,95\% } \\
\text { CI }\end{array}$ \\
\hline Johnson 1992 & $15 / 20$ & $18 / 18$ & 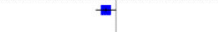 & $42.9 \%$ & $0.76[0.58,0.99]$ \\
\hline Subtotal $(95 \% \mathrm{CI})$ & 232 & 234 & - & $100.0 \%$ & $0.74[0.62,0.88]$ \\
\hline \multicolumn{6}{|c|}{ Total events: 89 (Restrictive), 122 (Liberal) } \\
\hline \multicolumn{6}{|c|}{ Heterogeneity, Tau ${ }^{2}=0.0 ; \mathrm{Ch}^{2}=0.08, \mathrm{df}=1(P=0.78) ; \mathrm{l}^{2}=0.0 \%$} \\
\hline Test for overall effect: $Z=$ & $=0.00065)$ & & & & \\
\hline & & & $\begin{array}{ccccccc}0.1 & 0.2 & 0.5 & 1 & 2 & 5 & 10 \\
\text { Fayours Restricitive } & \text { Favours Liberal }\end{array}$ & & \\
\hline
\end{tabular}




\section{Analysis 1.7}

\section{Comparison 1 Blood transfusions, Outcome 7 Units of blood transfused}

Review: Transfusion thresholds and other strategies for guiding allogeneic red blood cell transfusion

Comparison: 1 Blood transfusions

Outcome: 7 Units of blood transfused

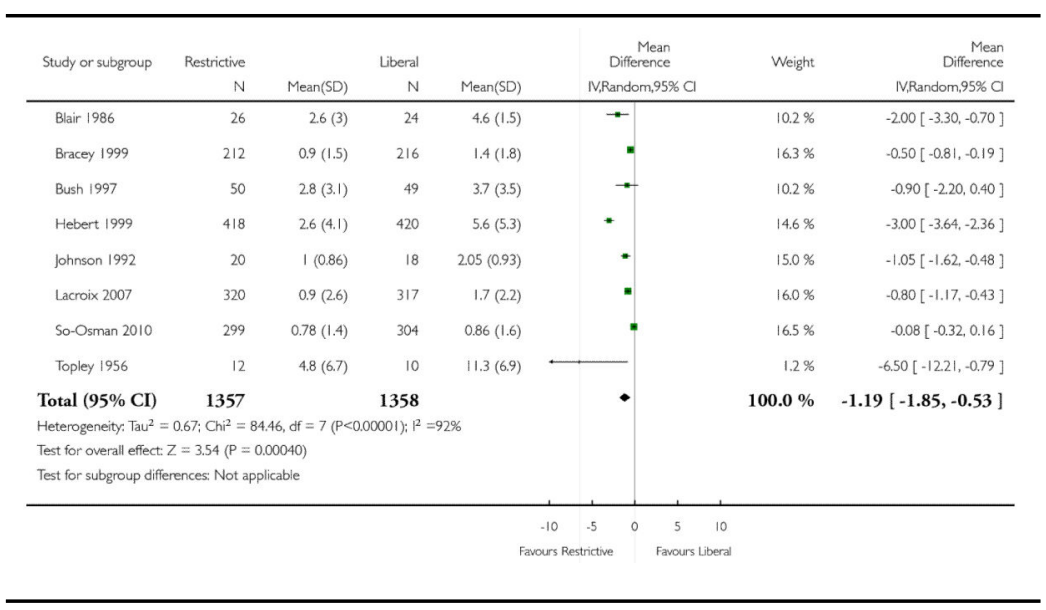

\section{Analysis 1.8}

Comparison 1 Blood transfusions, Outcome 8 Units of blood transfused in those transfused

Review: Transfusion thresholds and other strategies for guiding allogeneic red blood cell transfusion

Comparison: 1 Blood transfusions

Outcome: 8 Units of blood transfused in those transfused

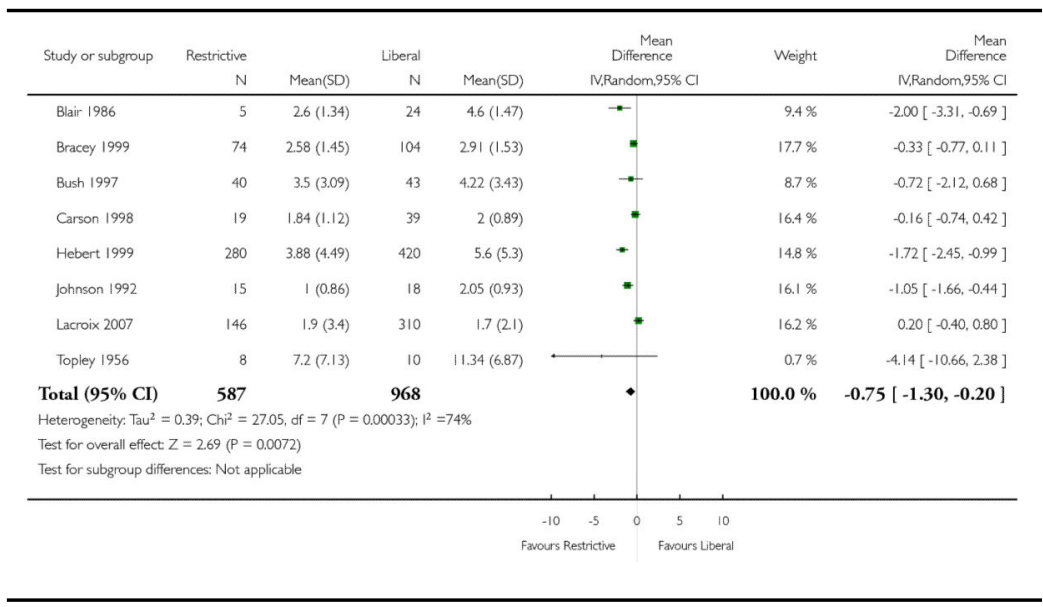




\section{Analysis 2.1}

\section{Comparison 2 Haemoglobin concentration, Outcome 1}

Haemoglobin concentration

Review: Transfusion thresholds and other strategies for guiding allogeneic red blood cell transfusion

Comparison: 2 Haemoglobin concentration

Outcome: 1 Haemoglobin concentration

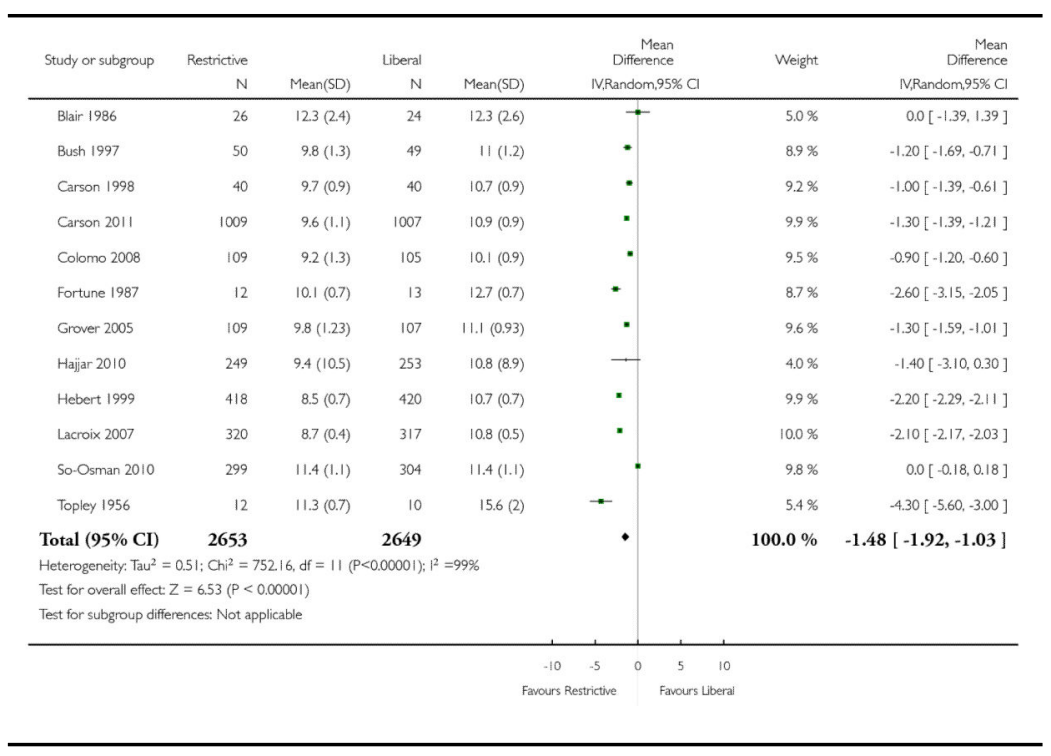

Analysis 3.1

Comparison 3 Mortality, Outcome $1 \leq 14$-day mortality

Review: Transfusion thresholds and other strategies for guiding allogeneic red blood cell transfusion

Comparison: 3 Mortality

Outcome: $1 \leq 14$-day mortality

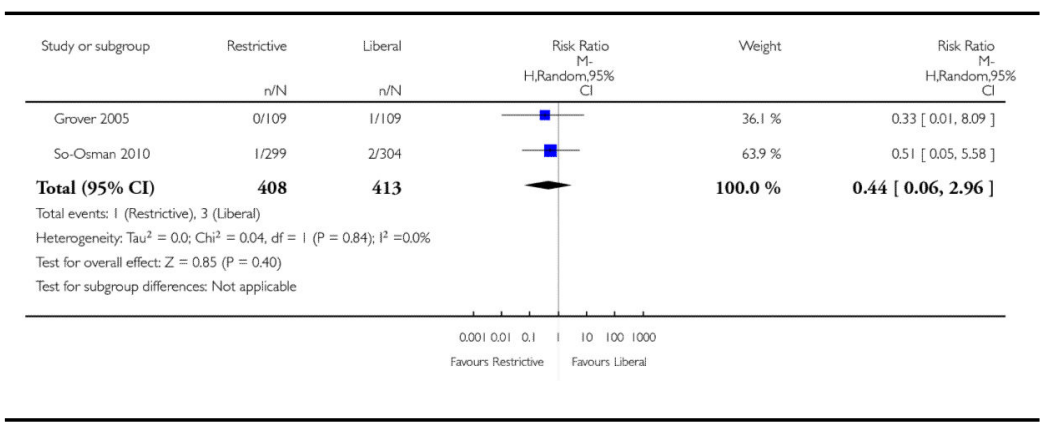




\section{Analysis 3.2}

\section{Comparison 3 Mortality, Outcome 2 30-day mortality}

Review: Transfusion thresholds and other strategies for guiding allogeneic red blood cell transfusion

Comparison: 3 Mortality

Outcome: 2 30-day mortality

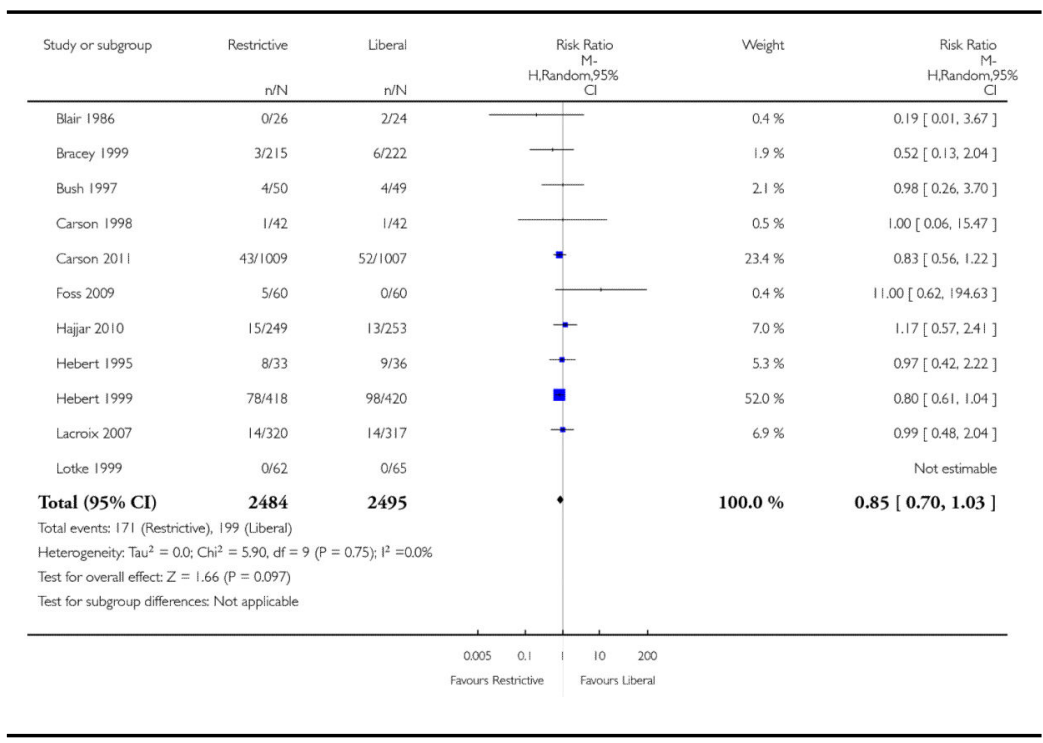

Analysis 3.3

Comparison 3 Mortality, Outcome 3 60-day mortality

Review: Transfusion thresholds and other strategies for guiding allogeneic red blood cell transfusion

Comparison: 3 Mortality

Outcome: 3 60-day mortality

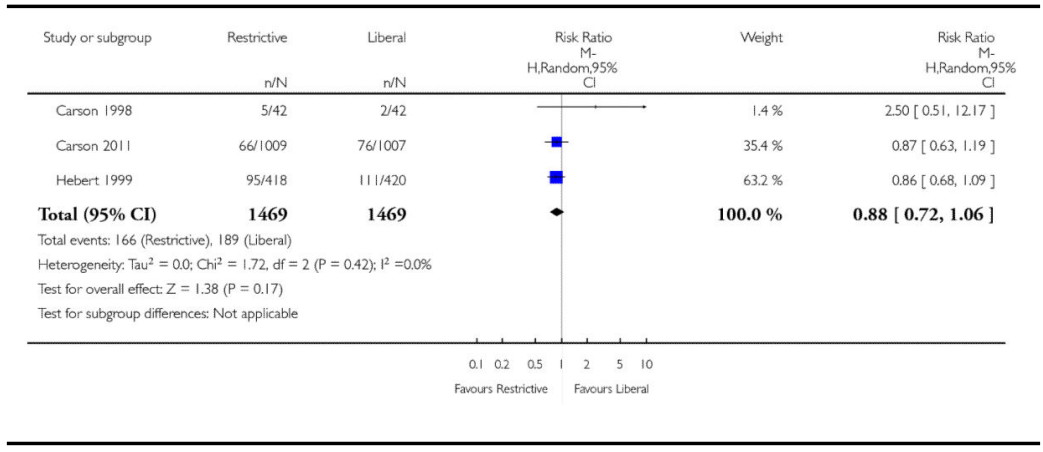


Analysis 3.4

Comparison 3 Mortality, Outcome 4 120-day mortality

Review: Transfusion thresholds and other strategies for guiding allogeneic red blood cell transfusion

Comparison: 3 Mortality

Outcome: 4 120-day mortality

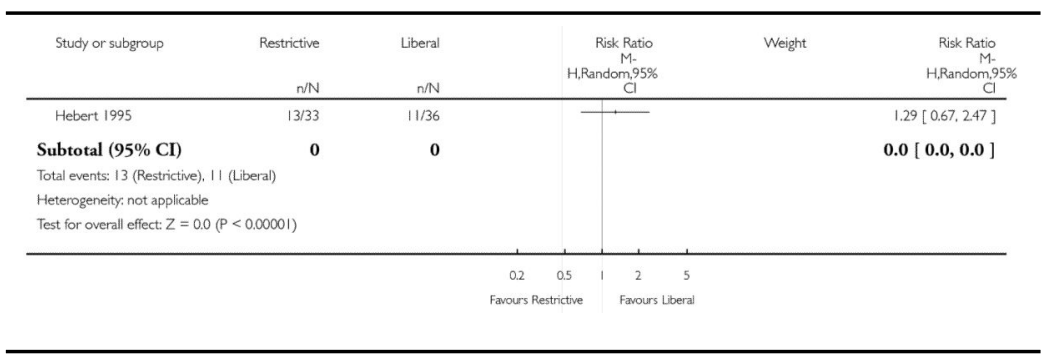

Analysis 3.5

Comparison 3 Mortality, Outcome 5 Hospital mortality

Review: Transfusion thresholds and other strategies for guiding allogeneic red blood cell transfusion

Comparison: 3 Mortality

Outcome: 5 Hospital mortality

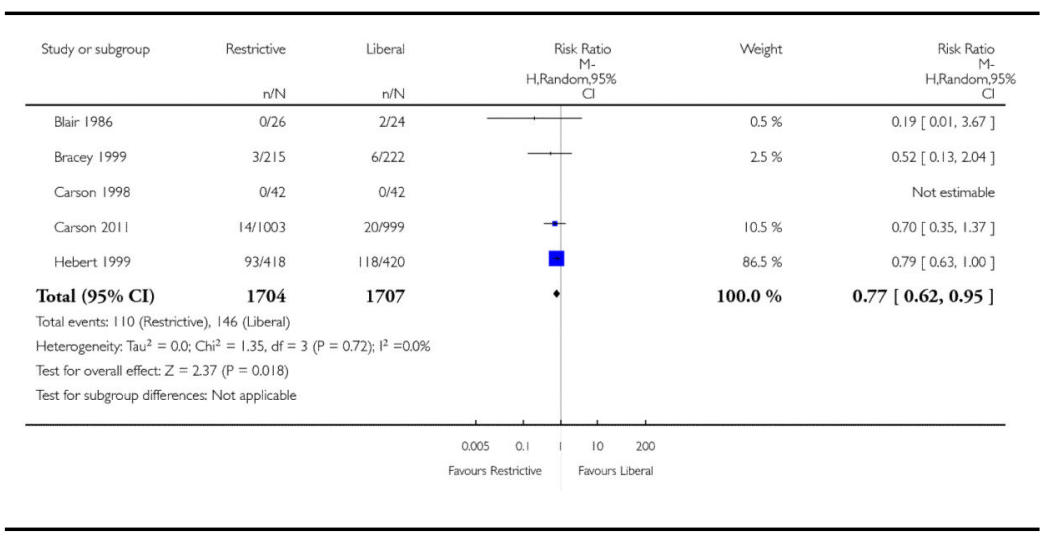


Analysis 3.6

Comparison 3 Mortality, Outcome 6 ICU mortality

Review: Transfusion thresholds and other strategies for guiding allogeneic red blood cell transfusion

Comparison: 3 Mortality

Outcome: 6 ICU mortality

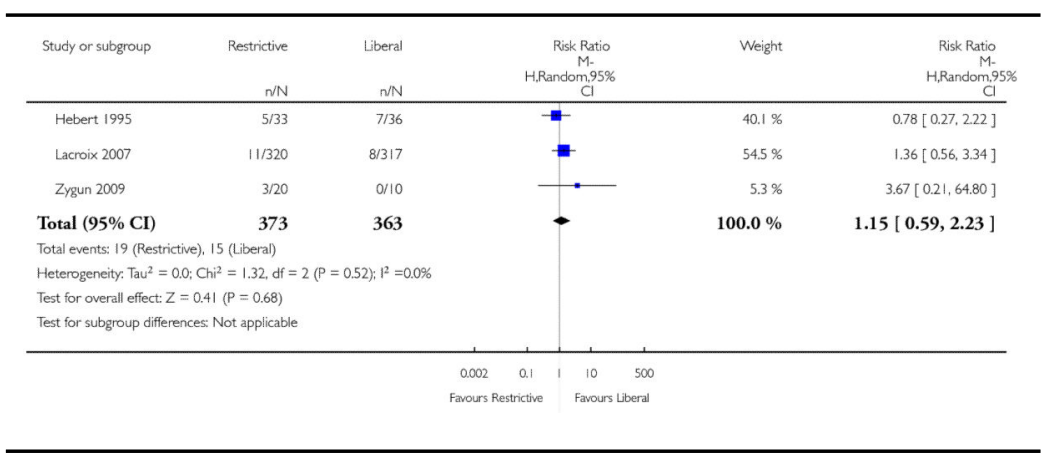

Analysis 3.7

Comparison 3 Mortality, Outcome 7 Mortality (unspecified follow-up period)

Review: Transfusion thresholds and other strategies for guiding allogeneic red blood cell transfusion

Comparison: 3 Mortality

Outcome: 7 Mortality (unspecified follow-up period)

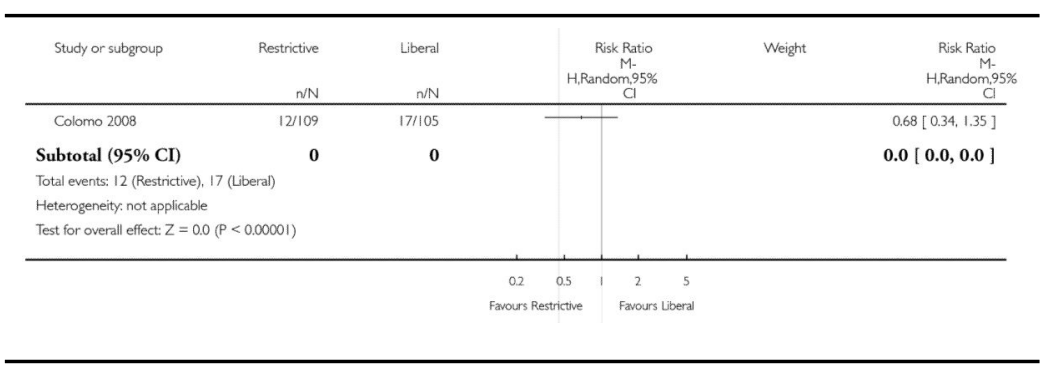


Analysis 4.1

\section{Comparison 4 Length of stay, Outcome 1 Hospital length of stay}

Review: Transfusion thresholds and other strategies for guiding allogeneic red blood cell transfusion

Comparison: 4 Length of stay

Outcome: 1 Hospital length of stay

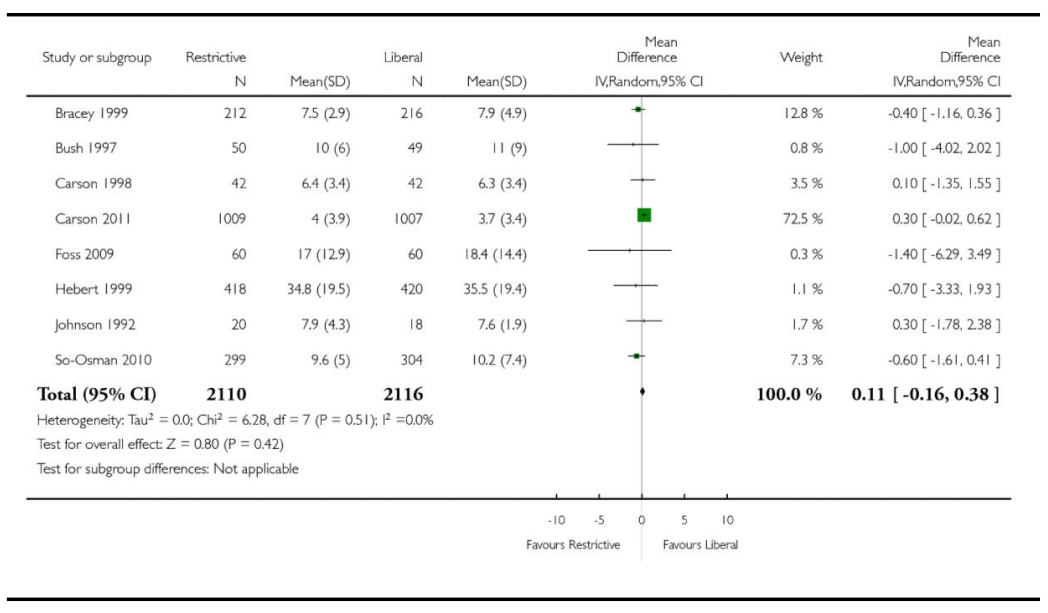

Analysis 4.2

Comparison 4 Length of stay, Outcome 2 ICU length of stay

Review: Transfusion thresholds and other strategies for guiding allogeneic red blood cell transfusion

Comparison: 4 Length of stay

Outcome: 2 ICU length of stay

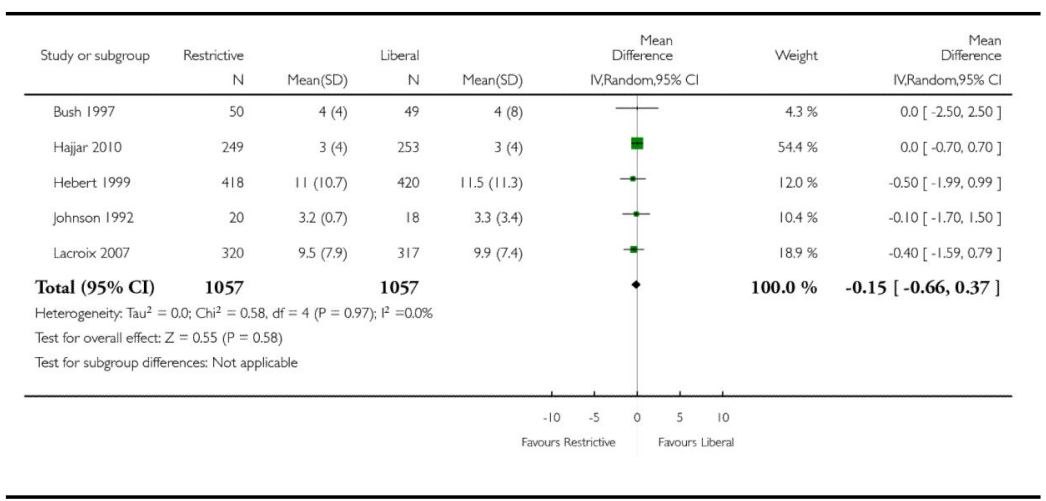




\section{Analysis 5.1}

\section{Comparison 5 Function and fatigue, Outcome 1}

Inability to walk or death at 30 days

Review: Transfusion thresholds and other strategies for guiding allogeneic red blood cell transfusion

Comparison: 5 Function and fatigue

Outcome: 1 Inability to walk or death at 30 days

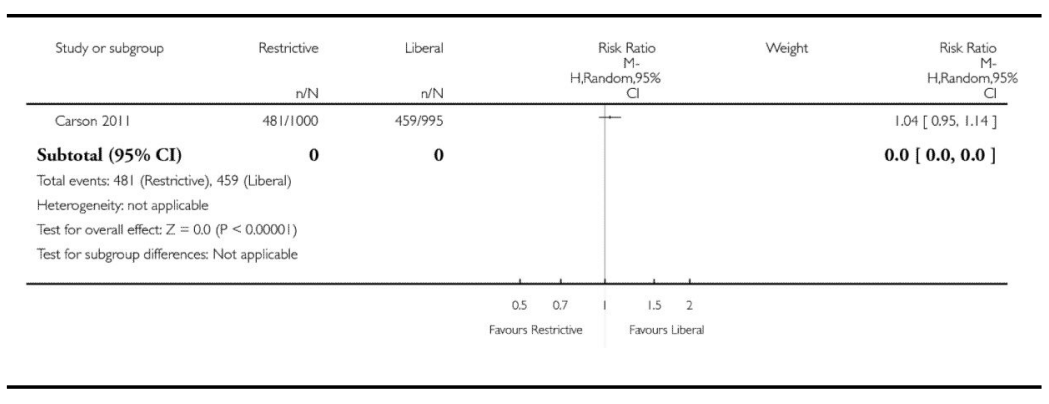

Analysis 5.2

Comparison 5 Function and fatigue, Outcome 2

Inability to walk or death at 60 days

Review: Transfusion thresholds and other strategies for guiding allogeneic red blood cell transfusion

Comparison: 5 Function and fatigue

Outcome: 2 Inability to walk or death at 60 days

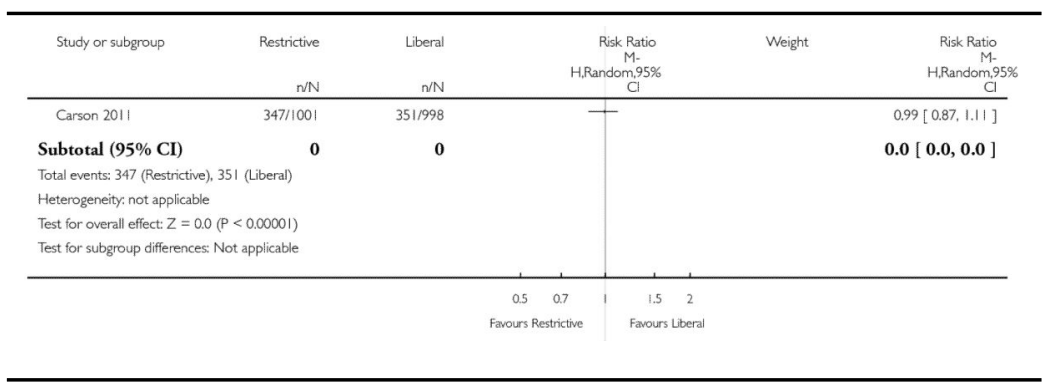




\section{Analysis 5.3}

Comparison 5 Function and fatigue, Outcome 3 Lower extremity physical activities of daily living at 30 days

Review: Transfusion thresholds and other strategies for guiding allogeneic red blood cell transfusion

Comparison: 5 Function and fatigue

Outcome: 3 Lower extremity physical activities of daily living at 30 days

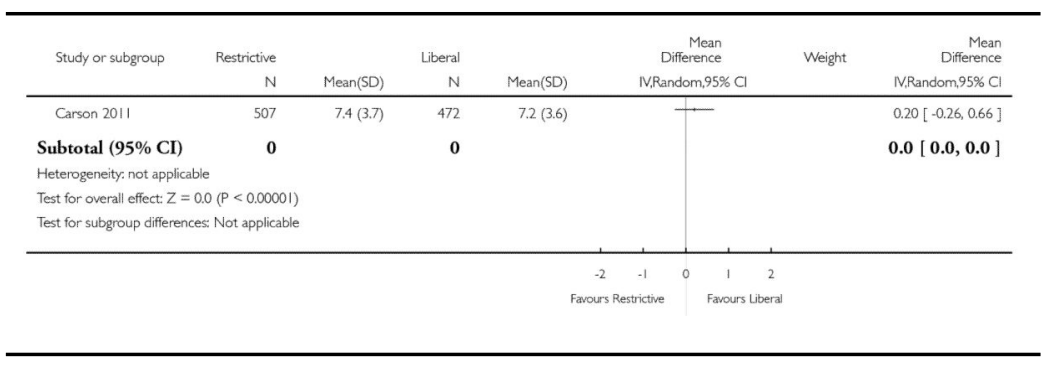

Analysis 5.4

Comparison 5 Function and fatigue, Outcome 4 Lower extremity physical activities of daily living at 60 days

Review: Transfusion thresholds and other strategies for guiding allogeneic red blood cell transfusion

Comparison: 5 Function and fatigue

Outcome: 4 Lower extremity physical activities of daily living at 60 days

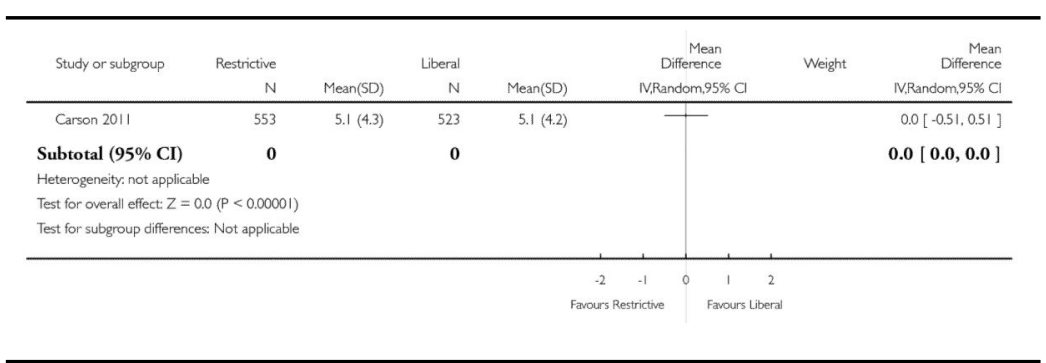




\section{Analysis 5.5}

Comparison 5 Function and fatigue, Outcome 5

Instrumental activities of daily living at 30 days

Review: Transfusion thresholds and other strategies for guiding allogeneic red blood cell transfusion

Comparison: 5 Function and fatigue

Outcome: 5 Instrumental activities of daily living at 30 days

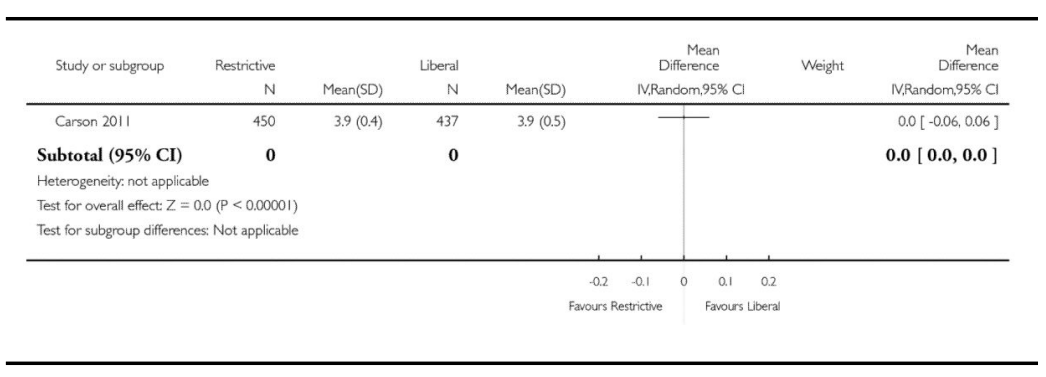

Analysis 5.6

Comparison 5 Function and fatigue, Outcome 6 Instrumental activities of daily living at 60 days

Review: Transfusion thresholds and other strategies for guiding allogeneic red blood cell transfusion

Comparison: 5 Function and fatigue

Outcome: 6 Instrumental activities of daily living at 60 days

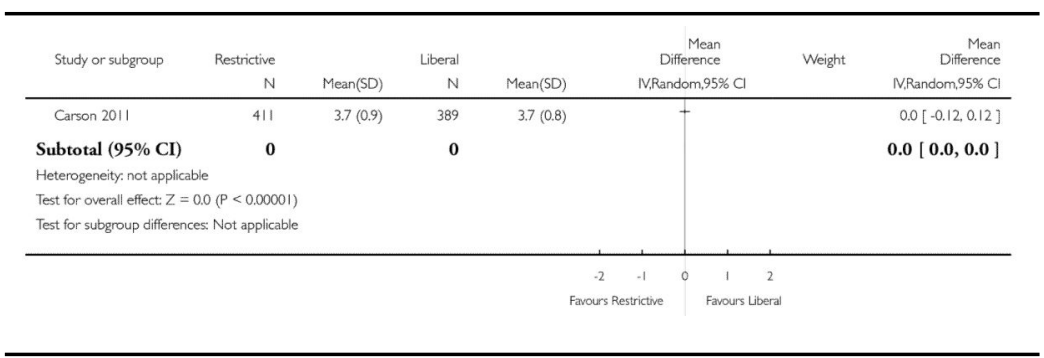




\section{Analysis 5.7}

Comparison 5 Function and fatigue, Outcome 7 Energy/ fatigue at 30 days

Review: Transfusion thresholds and other strategies for guiding allogeneic red blood cell transfusion

Comparison: 5 Function and fatigue

Outcome: 7 Energy/fatigue at 30 days

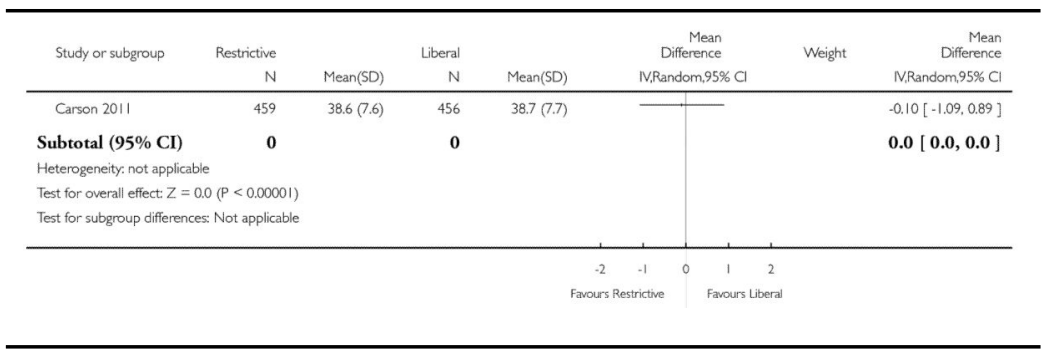

\section{Analysis 5.8}

Comparison 5 Function and fatigue, Outcome 8 Energy/ fatigue at 60 days

Review: Transfusion thresholds and other strategies for guiding allogeneic red blood cell transfusion

Comparison: 5 Function and fatigue

Outcome: 8 Energy/fatigue at 60 days

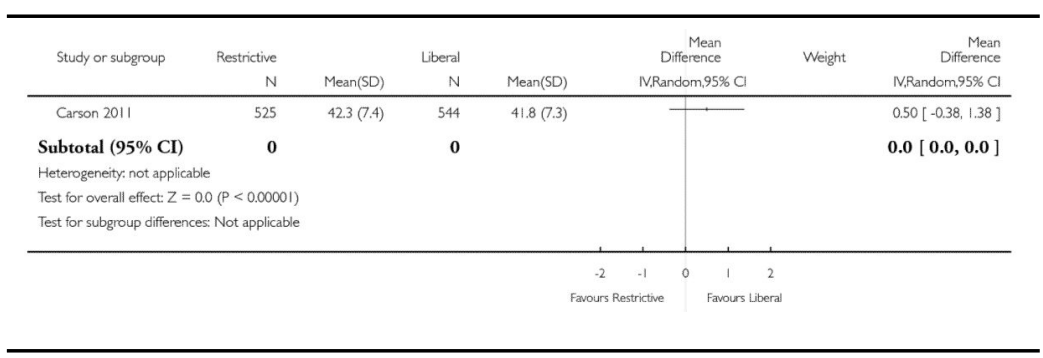




\section{Analysis 6.1}

\section{Comparison 6 Adverse events, Outcome 1 Cardiac} events

Review: Transfusion thresholds and other strategies for guiding allogeneic red blood cell transfusion

Comparison: 6 Adverse events

Outcome: 1 Cardiac events

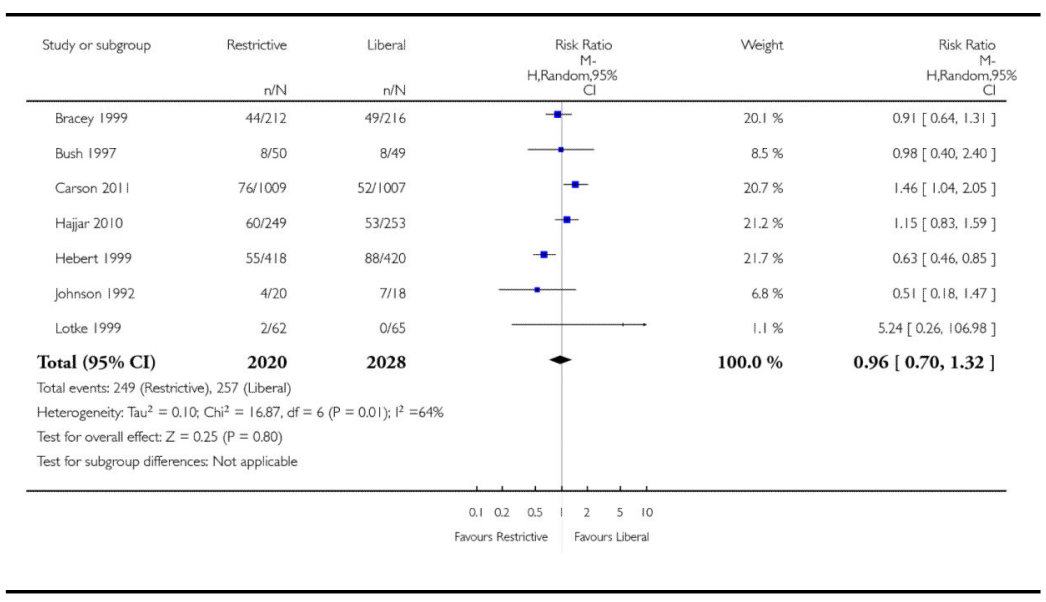

Analysis 6.2

Comparison 6 Adverse events, Outcome 2 Myocardial infarction

Review: Transfusion thresholds and other strategies for guiding allogeneic red blood cell transfusion

Comparison: 6 Adverse events

Outcome: 2 Myocardial infarction

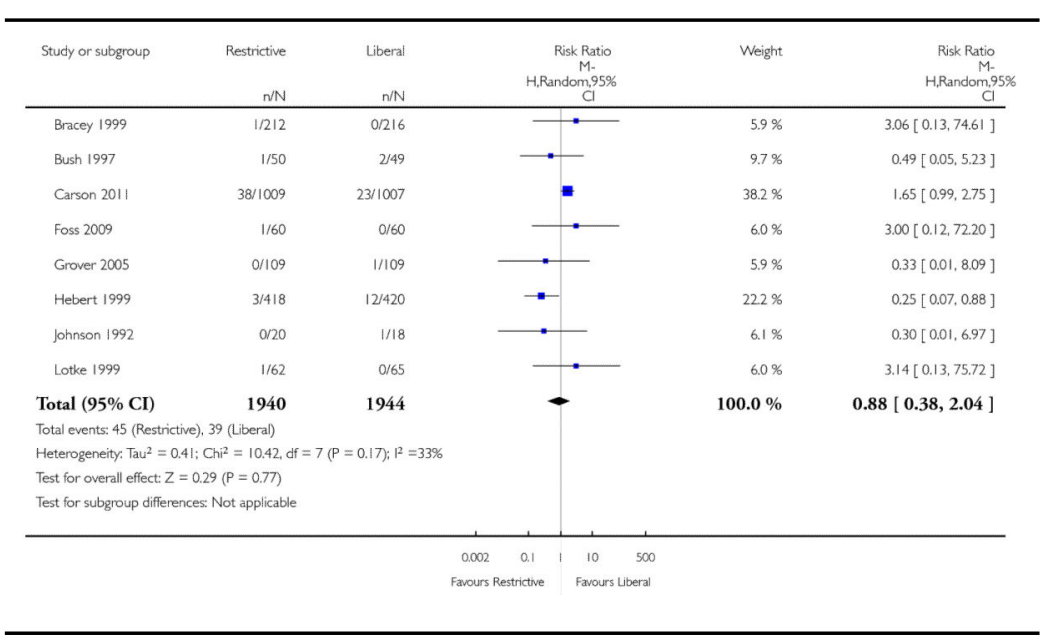




\section{Analysis 6.3}

\section{Comparison 6 Adverse events, Outcome 3 Pulmonary} oedema

Review: Transfusion thresholds and other strategies for guiding allogeneic red blood cell transfusion

Comparison: 6 Adverse events

Outcome: 3 Pulmonary oedema

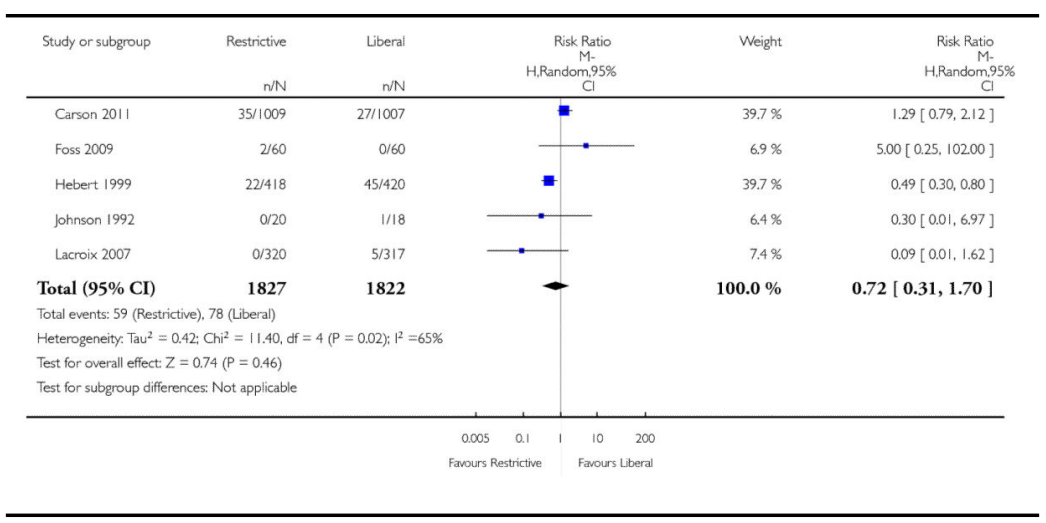

Analysis 6.4

Comparison 6 Adverse events, Outcome 4 Cerebrovascular accident (CVA) - stroke

Review: Transfusion thresholds and other strategies for guiding allogeneic red blood cell transfusion

Comparison: 6 Adverse events

Outcome: 4 Cerebrovascular accident (CVA) - stroke

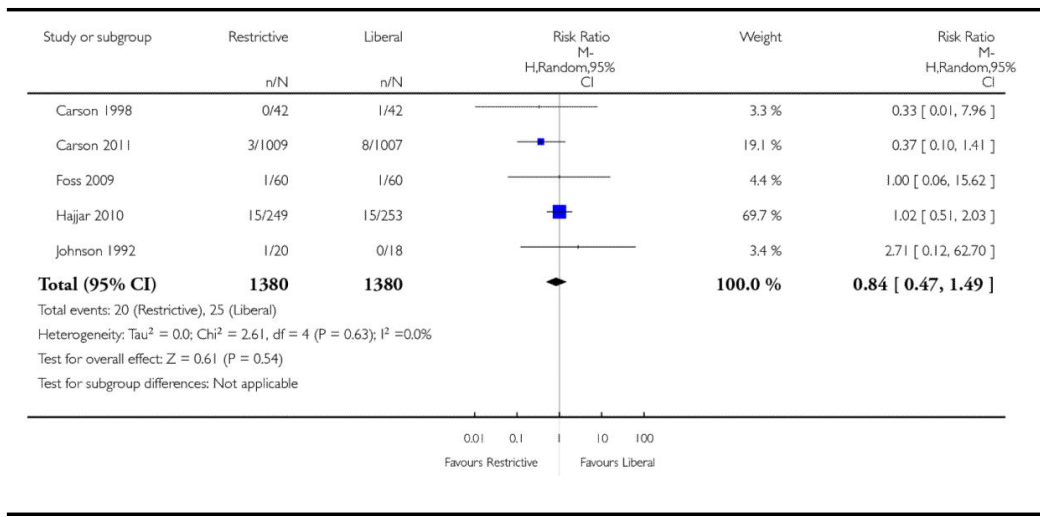


Analysis 6.5

\section{Comparison 6 Adverse events, Outcome 5 Pneumonia}

Review: Transfusion thresholds and other strategies for guiding allogeneic red blood cell transfusion

Comparison: 6 Adverse events

Outcome: 5 Pneumonia

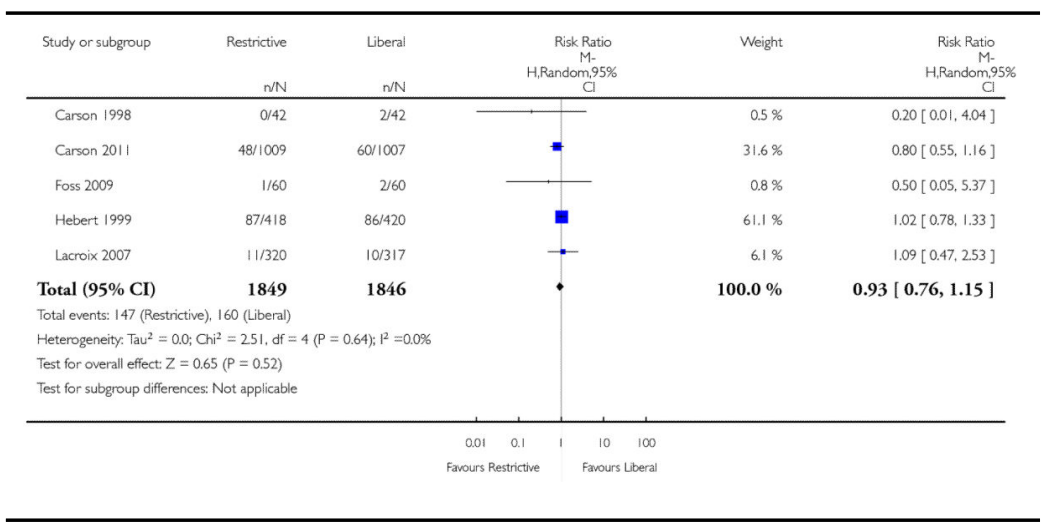

Analysis 6.6

Comparison 6 Adverse events, Outcome 6

Thromboembolism

Review: Transfusion thresholds and other strategies for guiding allogeneic red blood cell transfusion

Comparison: 6 Adverse events

Outcome: 6 Thromboembolism

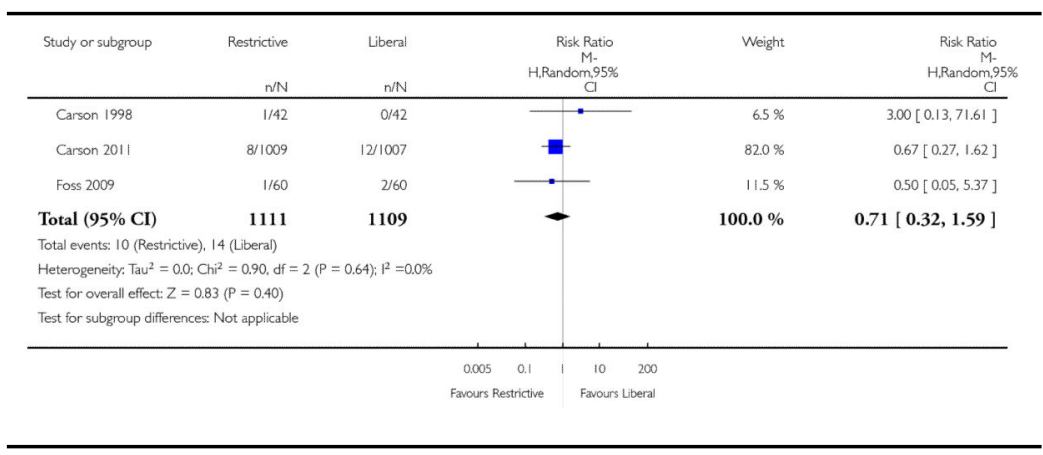


Analysis 6.7

\section{Comparison 6 Adverse events, Outcome 7 Rebleeding}

Review: Transfusion thresholds and other strategies for guiding allogeneic red blood cell transfusion

Comparison: 6 Adverse events

Outcome: 7 Rebleeding

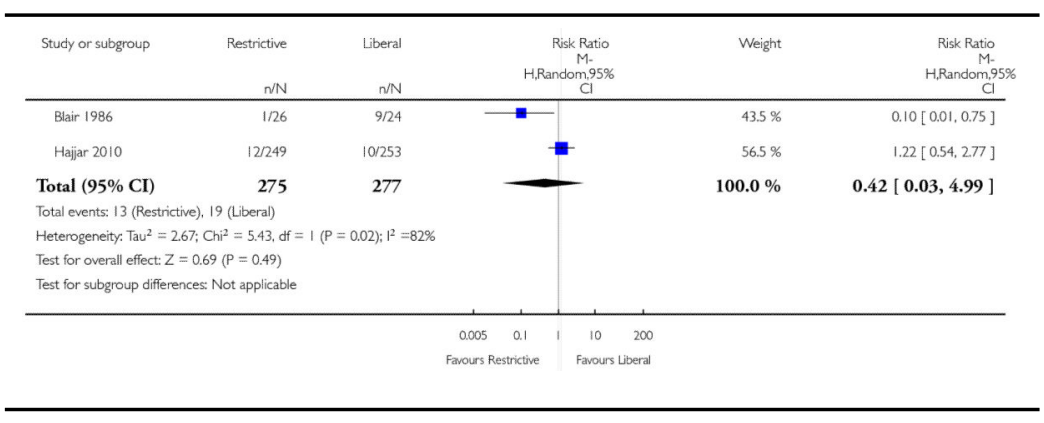

Analysis 6.8

Comparison 6 Adverse events, Outcome 8 Infection

Review: Transfusion thresholds and other strategies for guiding allogeneic red blood cell transfusion

Comparison: 6 Adverse events

Outcome: 8 Infection

\begin{tabular}{|c|c|c|c|c|c|}
\hline Study or subgroup & $\begin{array}{r}\text { Restrictive } \\
n / N\end{array}$ & $\begin{array}{r}\text { Liberal } \\
n / N\end{array}$ & $\begin{array}{c}\text { Risk Ratio } \\
\text { M- } \\
\text { H.Random.95\% } \\
\mathrm{Cl}\end{array}$ & Weight & $\begin{array}{c}\text { Risk Ratio } \\
\text { M- } \\
\text { H.Random,95\% } \\
\mathrm{CI}\end{array}$ \\
\hline Bracey 1999 & $5 / 212$ & $3 / 216$ & 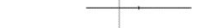 & $21 \%$ & $1.70[0.41,7.02]$ \\
\hline Carson 2011 & $56 / 1009$ & $74 / 1007$ & $\rightleftarrows$ & $29.2 \%$ & $0.76[0.54,1.06]$ \\
\hline Foss 2009 & 6160 & 11/60 & & $4.8 \%$ & $0.55[0.22,1.38]$ \\
\hline Hajar 2010 & $30 / 249$ & $25 / 253$ & & $15.0 \%$ & $1.22[0.74 .2 .01]$ \\
\hline Lacroix 2007 & $65 / 320$ & $79 / 317$ & $=$ & $36.6 \%$ & $0.82[0.61,1.09]$ \\
\hline So-Osman 2010 & 18/299 & 31/304 & $\cdot$ & $124 \%$ & $0.59[0.34,1.03]$ \\
\hline Total $(95 \% \mathrm{CI})$ & 2149 & 2157 & - & $100.0 \%$ & $0.81[0.66,1.00]$ \\
\hline \multicolumn{6}{|c|}{ Total events: 180 (Restrictive), 223 (Liberal) } \\
\hline \multicolumn{6}{|c|}{ Heterogeneity; Tau $^{2}=0.01 ;$ Chi $^{2}=5.70, d f=5(P=0.34) ; 1^{2}=12 \%$} \\
\hline \multicolumn{6}{|c|}{ Test for overal effect: $Z=1.99(P=0.046)$} \\
\hline \multicolumn{6}{|c|}{ Test for subgroup differences: Not applicable } \\
\hline & & & 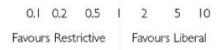 & & \\
\hline
\end{tabular}




\section{Analysis 6.9}

\section{Comparison 6 Adverse events, Outcome 9 Renal failure}

Review: Transfusion thresholds and other strategies for guiding allogeneic red blood cell transfusion

Comparison: 6 Adverse events

Outcome: 9 Renal failure

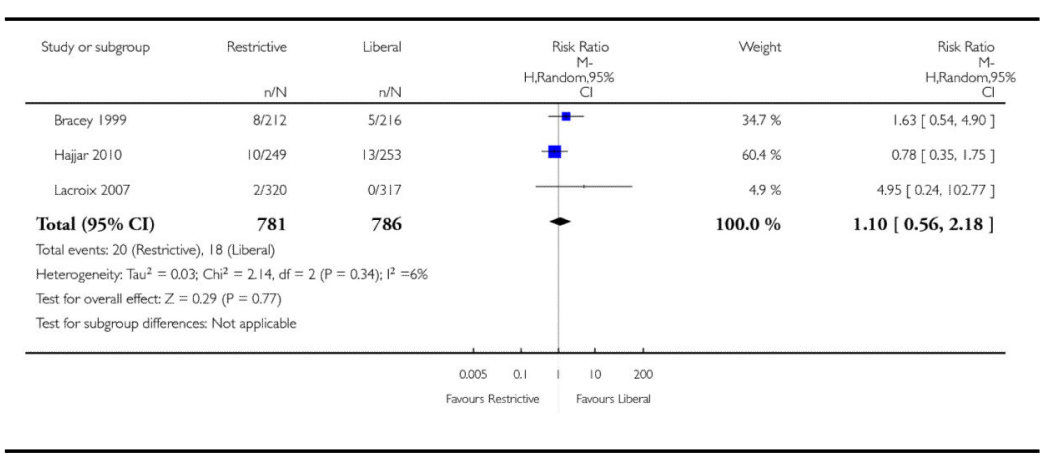

Analysis 6.10

Comparison 6 Adverse events, Outcome 10 Mental confusion

Review: Transfusion thresholds and other strategies for guiding allogeneic red blood cell transfusion

Comparison: 6 Adverse events

Outcome: 10 Mental confusion

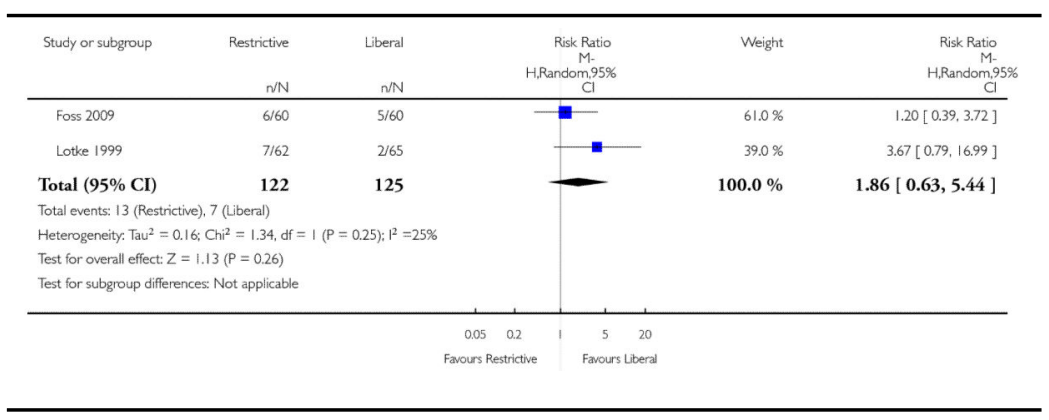

\section{WHAT'S NEW}

Last assessed as up-to-date: 1 February 2011.

\begin{tabular}{lll}
\hline Date & Event & Description \\
\hline 17 April 2012 & Amended & Minor copy edits were made to the text. \\
\hline
\end{tabular}




\section{HISTORY}

Protocol first published: Issue 2, 2000

Review first published: Issue 2, 2002

\begin{tabular}{|c|c|c|}
\hline Date & Event & Description \\
\hline 20 December 2011 & $\begin{array}{l}\text { New citation } \\
\text { required and } \\
\text { conclusions have } \\
\text { changed }\end{array}$ & $\begin{array}{l}\text { The searches were updated to February 2011. Data from two new trials are } \\
\text { included and the results have been amended accordingly. One trial was } \\
\text { identified through the updated search; the other had previously been } \\
\text { included as an ongoing trial and the results recently became available } \\
\text { The Background section of the review has been updated. The overall } \\
\text { conclusions of the review remain similar but the clinical settings for which } \\
\text { the results can be generalised have been extended } \\
\text { As part of this update the assessment of methodological quality used in } \\
\text { earlier versions of this review has been replaced with an assessment of the } \\
\text { risk of bias. This amendment is in accordance with a change in the } \\
\text { Cochrane Collaboration's methodological guidance The authors of the } \\
\text { review have changed. }\end{array}$ \\
\hline 1 February 2011 & $\begin{array}{l}\text { New search has } \\
\text { been performed }\end{array}$ & The search for studies was updated to February 2011. \\
\hline 9 September 2008 & Amended & Converted to new review format. \\
\hline 17 November 2004 & $\begin{array}{l}\text { New search has } \\
\text { been performed }\end{array}$ & $\begin{array}{l}\text { An updated search for new trials was conducted in November 2004. No } \\
\text { new trials for inclusion were identified }\end{array}$ \\
\hline
\end{tabular}

\section{DIFFERENCES BETWEEN PROTOCOL AND REVIEW}

There were no differences identified.

\section{References to studies included in this review}

Blair 1986 \{published data only\} . Blair SD, Janvrin SB, McCollum CN, Greenhalgh RM. Effect of early blood transfusion on gastrointestinal haemorrhage. British Journal of Surgery. 1986; 73(10):783-5. [PubMed: 3533203]

Bracey 1999 \{published data only\} . Bracey AW, Radovancevic R, Riggs SA, Houston S, Cozart $\mathrm{H}$, Vaughn WK, et al. Lowering the hemoglobin threshold for transfusion in coronary artery bypass procedures: effect on patient outcome. Transfusion. 1999; 39(10):1070-7. [PubMed: 10532600]

Bush 1997 \{published data only\} . Bush RL, Pevec WC, Holcroft JW. A prospective, randomized trial limiting perioperative red blood cell transfusions in vascular patients. American Journal of Surgery. 1997; 174(2):143-8. [PubMed: 9293831]

Carson 1998 \{published data only . Carson JL, Terrin ML, Barton FB, Aaron R, Greenburg AG, Heck DA, et al. A pilot randomized trial comparing symptomatic vs. hemoglobin-level-driven red blood cell transfusions following hip fracture. Transfusion. 1998; 38(6):522-9. [PubMed: 9661685]

Carson 2011 \{published data only\} . Carson JL, Terrin ML, Noveck H, Sanders DW, Chaitman BR, Rhoads GR, et al. Liberal or restrictive transfusion in high-risk patients after hip surgery. New England Journal of Medicine. 2011; 365(26):2453-62. [PubMed: 22168590]

Colomo 2008 \{published data only . Colomo A, Hernandez-Gea V, Muniz-Diaz E, Madoz P, Aracil C, Alvarez-Urturi C, et al. Transfusion strategies in patients with cirrhosis and acute gastrointestinal bleeding. Hepatology. 2008; $48(4$ (Suppl)):413A.

Fortune 1987 \{published data only\} . Fortune JB, Feustel PJ, Saifi J, Stratton HH, Newell JC, Shah DM. Influence of hematocrit on cardiopulmonary function after acute hemorrhage. Journal of Trauma. 1987; 27(3):243-9. [PubMed: 3560265] 
Foss 2009 \{published data only\} . Foss NB, Kristensen MT, Jensen PS, Palm H, Krasheninnikoff $\mathrm{M}$, Kehlet $\mathrm{H}$. The effects of liberal versus restrictive transfusion thresholds on ambulation after hip fracture surgery. Transfusion. 2009; 49(2):227-34. [PubMed: 19389209]

Grover 2005 \{published data only\} * *Grover M, Talwalkar S, Casbard A, Boralessa H, Contreras M, Boralessa H, et al. Silent myocardial ischaemia and haemoglobin concentration: a randomized controlled trial of transfusion strategy in lower limb arthroplasty. Vox Sanguinis. 2006; 90:10512. [PubMed: 16430668]

Grover M, Talwalker SA, Contreras Soni N. Blood transfusion threshold and silent myocardial ischemia after lower limb arthroplasty: a randomized controlled trial of transfusion strategy. Transfusion Alternatives in Transfusion Medicine. 2005; 7(1 (Suppl)):62-3.

Hajjar 2010 \{published data only\} . Hajjar LA, Vincent JL, Galas FRGB, Nakamura RE, Silva CMP, Santos MH, et al. Transfusion requirements after cardiac surgery. The TRACS randomized controlled trial. JAMA. 2010; 304(14):1559-67. [PubMed: 20940381]

Hebert 1995 \{published data only\} . Hebert PC, Wells G, Marshall J, Martin C, Tweeddale M, Pagliarello G, et al. Transfusion requirements in critical care. A pilot study. Canadian Critical Care Trials Group. JAMA. 1995; 273(18):1439-44. published erratum appears in JAMA 1995 Sep 27;274(12): 944. [PubMed: 7723158]

Hebert 1999 \{published data only . *Hebert PC. A multicenter, randomized, controlled clinical trial of transfusion requirements in critical care. New England Journal of Medicine. 1999; 340(6): 409-17. [PubMed: 9971864]

McIntyre L, Hebert PC, Wells G, Fergusson D, Marshall J, Yetisir E, et al. Canadian Critical Care Trials Group. Is a restrictive transfusion strategy safe for resuscitated and critically ill trauma patients? Journal of Trauma. 2004; 57(3):563-8. [PubMed: 15454803]

McIntyre LA, Fergusson DA, Hutchison JS, Pagliarello G, Marshall JC, Yetisir E, et al. A pilot randomized trial comparing symptomatic vs. hemoglobin-level-driven red blood cell transfusions following hip fracture. Transfusion. 1998; 38(6):522-9. [PubMed: 9661685]

Johnson 1992 \{published data only\} . Johnson RG, Thurer RL, Kruskall MS, Sirois C, Gervino $\mathrm{EV}$, Critchlow J, et al. Comparison of two transfusion strategies after elective operations for myocardial revascularization. Journal of Thoracic \& Cardiovascular Surgery. 1992; 104(2):30714. [PubMed: 1495291]

Lacroix 2007 \{published data only\} . Lacroix J, Hébert PC, Hutchison JS, Hume HA, Tucci M, Ducruet T, et al. Transfusion strategies for patients in pediatric intensive care units. New England Journal of Medicine. 2007; 356(16):1609-19. [PubMed: 17442904]

Lotke 1999 \{published data only\} . Lotke PA, Barth P, Garino JP, Cook EF. Predonated autologous blood transfusions after total knee arthroplasty: immediate versus delayed administration. Journal of Arthroplasty. 1999; 14(6):647-50. [PubMed: 10512433]

So-Osman 2010 \{published data only\} . So-Osman C. A restrictive transfusion trigger is a method for blood saving in elective orthopaedic surgery. Vox Sanguinis. 2004; 87(Suppl 3):52. [PubMed: 15209879]

*So-Osman C, Nelissen R, Te Slaa R, Coene L, Brand R, Brand A. A randomized comparison of transfusion triggers in elective orthopaedic surgery using leucocyte-depleted red blood cells. Vox Sanguinis. 2010; 98:56-64. [PubMed: 19656349]

Topley 1956 \{published data only\} . Topley ET, Fisher MR. The illness of trauma. British Journal of Clinical Practice. 1956; 10(11):770-6. [PubMed: 13374186]

Webert 2008 \{published data only\} . Webert KE, Cook RJ, Couban S, Carruthers J, Lee KA, Blajchman MA, et al. A multicenter pilot-randomized controlled trial of the feasibility of an augmented red blood cell transfusion strategy for patients treated with induction chemotherapy for acute leukemia or stem cell transplantation. Transfusion. 2008; 48(1):81-91. [PubMed: 17894791]

Zygun 2009 \{published data only . Zygun DA, Nortje J, Hutchinson PJ, Timofeev I, Menon DK, Gupta AK. The effect of red blood cell transfusion on cerebral oxygenation and metabolism after severe traumatic brain injury. Critical Care Medicine. 2009; 37(3):1074-8. [PubMed: 19237920] 


\section{References to studies excluded from this review}

Vichinsky 1995 \{published data only\} . Vichinsky EP, Haberkern CM, Neumayr L, Earles AN, Black D, Koshy M, et al. The Preoperative Transfusion in Sickle Cell Disease Study Group. A comparison of conservative and aggressive transfusion regimens in the perioperative management of sickle cell disease. New England Journal of Medicine. 1995; 333(4):206-13. [PubMed: 7791837]

\section{References to studies awaiting assessment}

Cooper 2011 \{published data only\} . Cooper HA, Rao SV, Greenberg MD, Rumsey MP, Mckenzie $\mathrm{M}$, Alcorn KW, et al. Conservative versus liberal red cell transfusion in acute myocardial infarction (the CRIT randomized pilot study). American Journal of Cardiology. 2011; 108:110811. [PubMed: 21791325]

\section{References to ongoing studies}

MINT \{published data only\} . Carson, JL.; Noveck, H. Myocardial Ischemia and Transfusion (MINT). http://www.ClinicalTrials.gov. [: NCT01167582]

TITRe 2 \{published data only\} . Reeves, B. A multi-centre randomised controlled trial of the effects of a reduction in the threshold for blood transfusion following heart surgery. http:// www.controlled-trials.com. [: ISRCTN70923932]

\section{Additional references}

AAGBI 2008 . Association of Anaesthetists of Great Britain and Ireland. Blood transfusion and the anaesthetist - red cell transfusion. Jun 1-20. 2008 http://www.aagbi.org/publications/guidelines/ docs/redcell08.pdfhttp://www.aagbi.org/publications/guidelines/docs/redcell08.pdf

Amin 2004 . Amin M, Fergusson D, Wilson K, Tinmouth A, Aziz A, Coyle D, et al. The societal unit cost of allogenic red blood cells and red blood cell transfusion in Canada. Transfusion. 2004; 44(10):1479-86. [PubMed: 15383022]

ASA 2006 . American Society of Anesthesiologists Task Force on Perioperative Blood Transfusion and Adjuvant Therapies. Practice guidelines for perioperative blood transfusion and adjuvant therapies. Anesthesiology. 2006; 105(1):198-208. [PubMed: 16810012]

ASBT 2001 . National Health and Medical Research Council (NHMRC); Australasian Society of Blood Transfusion (ASBT). Clinical Practice Guidelines: Appropriate Use of Red Blood Cells. 2001

BCTMAG 2003 . Guidelines for Red Blood Cell Transfusion. British Columbia Transfusion Medicine Advisory Group; Nov 1-3. 2003

Benson 2000 . Benson K, Hartz AJ. A comparison of observational studies and randomized, controlled trials. New England Journal of Medicine. 2000; 342(25):1878-86. [PubMed: 10861324]

Carless 2010 . Carless PA, Henry DA, Moxey AJ, O’Connell D, Brown T, Fergusson DA. Cell salvage for minimising perioperative allogeneic blood transfusion. Cochrane Database of Systematic Reviews. 2010; (4) DOI: 10.1002/14651858.CD001888.pub4.

Concato 2000 . Concato J, Shah N, Horwitz RI. Randomized, controlled trials, observational studies, and the hierarchy of research designs. New England Journal of Medicine. 2000; 342(25):188792. [PubMed: 10861325]

Der Simonian 1986 . Der Simonian R, Laird N. Meta-analysis in clinical trials. Controlled Clinical Trials. 1986; 7:177-88. [PubMed: 3802833]

Goodnough 2008 . Goodnough LT, Shander A. Risks and complications of blood transfusions: optimizing outcomes for patients with chemotherapy-induced anemia. Advanced Studies in Medicine. 2008; 8(10):357-62. 
Hebert 1997 . Hebert PC, Wells G, Tweeddale M, Martin C, Marshall J, Pham B, et al. Does transfusion practice affect mortality in critically ill patients? Transfusion Requirements in Critical Care (TRICC) Investigators and the Canadian Critical Care Trials Group. American Journal of Respiratory \& Critical Care Medicine. 1997; 155(5):1618-23. [PubMed: 9154866]

Henry 2001a . Henry, DA.; Moxey, AJ.; O’Connell, D. Agreement between randomised and nonrandomised studies - the effects of bias and confounding; Poster presentation - 9th Cochrane Colloquium; Lyon, France. Oct 9-13.

Henry 2011b . Henry DA, Carless PA, Moxey AJ, O’Connell D, Stokes BJ, Ferugsson DA, et al. Anti-fibrinolytic use for minimising perioperative allogeneic blood transfusion. Cochrane Database of Systematic Reviews. 2011; (3) DOI: 10.1002/14651858.CD001886.pub4.

Higgins 2011 . Higgins, JPT.; Green, S., editors. Cochrane Handbook for Systematic Reviews of Interventions Version 5.1.0. The Cochrane Collaboration; 2011. updated March 2011Available from www.cochrane-handbook.org

Ioannidis 2001 . Ioannidis JPA, Haidich AB, Pappa M, Pantazis N, Kokori SI, Tektonidou MG, et al. Comparison of evidence of treatment effects in randomised and nonrandomised studies. JAMA. 2001; 286:821-30. [PubMed: 11497536]

Kitchen 2008 . Kitchen AD, Barbara JAJ. Current information on the infectious risks of allogeneic blood transfusion. Transfusion Alternative in Transfusion Medicine. 2008; 10:102-11.

Klein 2007 . Klein HG, Spahn DR, Carson JL. Red blood cell transfusion in clinical practice. Lancet. 2007; 370(9585):415-26. [PubMed: 17679019]

Madjdpour 2005 . Madjdpour C, Spahn DR. Allogeneic red blood cell transfusions: efficacy, risks, alternatives and indications. British Journal of Anaesthesia. 2005; 95(1):33-42. [PubMed: 15486006]

Napolitano 2009 . Napolitano LM, Kurek S, Luchette FA, Corwin HL, Barie PS, Tisherman SA, et al. Clinical practice guideline: red blood cell transfusion in adult trauma and critical care. Critical Care Medicine. 2009; 37(12):3124-57. [PubMed: 19773646]

NBUGI 2001 . National Blood Users Group Ireland. A Guideline for Transfusion of Red Blood Cells in Surgical Patients. Jan 1-20. 2001 http://www.dohc.ie/publications/ transfusionofredbloodcells.htmlhttp://www.dohc.ie/publications/transfusionofredbloodcells.html

NIH 1988 . National Institutes of Health. Perioperative red blood cell transfusion. JAMA. 1988; 260:2700-3. [PubMed: 3054179]

O’Brien 2007 . O’Brien SF, Yi QL, Fan W, Scalia V, Kleinman SH, Vamvakas EC. Current incidence and estimated residual risk of transfusion-transmitted infections in donations made to Canadian Blood Services. Transfusion. 2007; 47(2):316-25. [PubMed: 17302779]

Review Manager . The Nordic Cochrane Centre. The Cochrane Collaboration. Review Manager (RevMan). 5.1. The Nordic Cochrane Centre, The Cochrane Collaboration; Copenhagen: 2011.

Schulz 1995 . Schulz KF, Chalmers I, Hayes RJ, Altman DJ. Empirical evidence of bias. Dimensions of methodological quality associated with estimates of treatment effects in controlled clinical trials. JAMA. 1995; 273:408-12. [PubMed: 7823387]

Shander 2010 . Shander A, Hofmann A, Ozawa S, Theusinger OM, Gomboz H, Spahn DR. Activitybased costs of blood transfusions in surgical patients at four hospitals. Transfusion. 2010; 50(4): 753-65. [PubMed: 20003061]

Spiess 1998 . Spiess BD, Ley C, Body SC, Siegel LC, Stover EP, Maddi R, et al. The Institutions of the Multicenter Study of Perioperative Ischemia (McSPI) Research Group. Hematocrit value on intensive care unit entry influences the frequency of Q-wave myocardial infarction after coronary artery bypass grafting. Journal of Thoracic \& Cardiovascular Surgery. 1998; 116(3):460-7. [PubMed: 9731788]

Wang 2010 . Wang JK, Klein HG. Red blood cell transfusion in the treatment and management of anaemia: the search for the elusive transfusion trigger. Vox Sanguinis. 2010; 98(1):2-11. [PubMed: 19682346]

Weiskopf 2000 . Weiskopf RB, Kramer JH, Viele M, Neumann M, Feiner JR, Watson JJ, et al. Acute severe isovolemic anemia impairs cognitive function and memory in humans. Anesthesiology. 2000; 92(6):1646-52. [PubMed: 10839915] 
Whitaker 2011 . U.S. Department of Health and Human Services, Office of the Assistant Secretary for Health. Report of the US Department of Health and Human Services. The 2009 national blood collection and utilization survey report. U.S. Department of Health and Human Services, Office of the Assistant Secretary for Health; 2011.

WHO 2011 . WHO. Blood safety: key global facts and figures in 2011. 2011; 279:1-9. Fact Sheet. http://www.who.int/worldblooddonorday/media/whobloodsafetyfactsheet2011.pdf

Wu 2001 . Wu WC, Rathore SS, Wang Y, Radford MJ, Krumholz HM. Blood transfusion in elderly patients with acute myocardial infarction. New England Journal of Medicine. 2001; 345(17): 1230-6. [PubMed: 11680442]

Wu 2007 . Wu WC, Schifftner TL, Henderson WG, Eaton CB, Poses RM, Uttley G, et al. Preoperative hematocrit levels and postoperative outcomes in older patients undergoing noncardiac surgery. JAMA. 2007; 297(22):2481-8. [PubMed: 17565082]

Wu 2010 . Wu WC, Smith TS, Henderson WG, Eaton CB, Poses RM, Uttley G, et al. Operative blood loss, blood transfusion, and 30-day mortality in older patients after major noncardiac surgery. Annals of Surgery. 2010; 252(1):11-7. [PubMed: 20505504]

Zou 2009 . Zou S, Stramer SL, Notari EP, Kuhns MC, Krysztof D, Musavi F, et al. Current incidence and residual risk of hepatitis B infection among blood donors in the United States. Transfusion. 2009; 49(8):1609-20. [PubMed: 19413732]

Zou 2010 .Zou S, Dorsey KA, Notari EP, Foster GA, Krysztof DE, Musavi F, et al. Prevalence, incidence, and residual risk of human immunodeficiency virus and hepatitis $\mathrm{C}$ virus infections among United States blood donors since the introduction of nucleic acid testing. Transfusion. 2010; 50(7):1495-504. [PubMed: 20345570]

* Indicates the major publication for the study 


\section{PLAIN LANGUAGE SUMMARY}

\section{Restricting the use of blood transfusion}

Many people are given a transfusion of blood from an unrelated donor as part of their medical treatment. There are, however, risks involved. In particular, infections (including HIV and certain types of hepatitis) may be passed on to the person receiving the blood. This risk is very small in high-income countries but much larger in poor countries which do not test the blood for infections. Because of the risks, doctors try to avoid giving blood unless it is really necessary. One approach is to give the transfusion only if the amount of haemoglobin in the patient's blood has dropped below a certain 'threshold' level. We looked for controlled studies comparing the effectiveness of giving more versus less blood. We found 19 studies, with a total of 6264 patients. We conclude that, for most patients, giving less blood is safe and blood transfusion is probably not essential until haemoglobin levels drop below 7.0 to 8.0 grams per decilitre. As no trials have been done involving patients with an acute heart problem, it is not currently known how much blood to give these patients. 


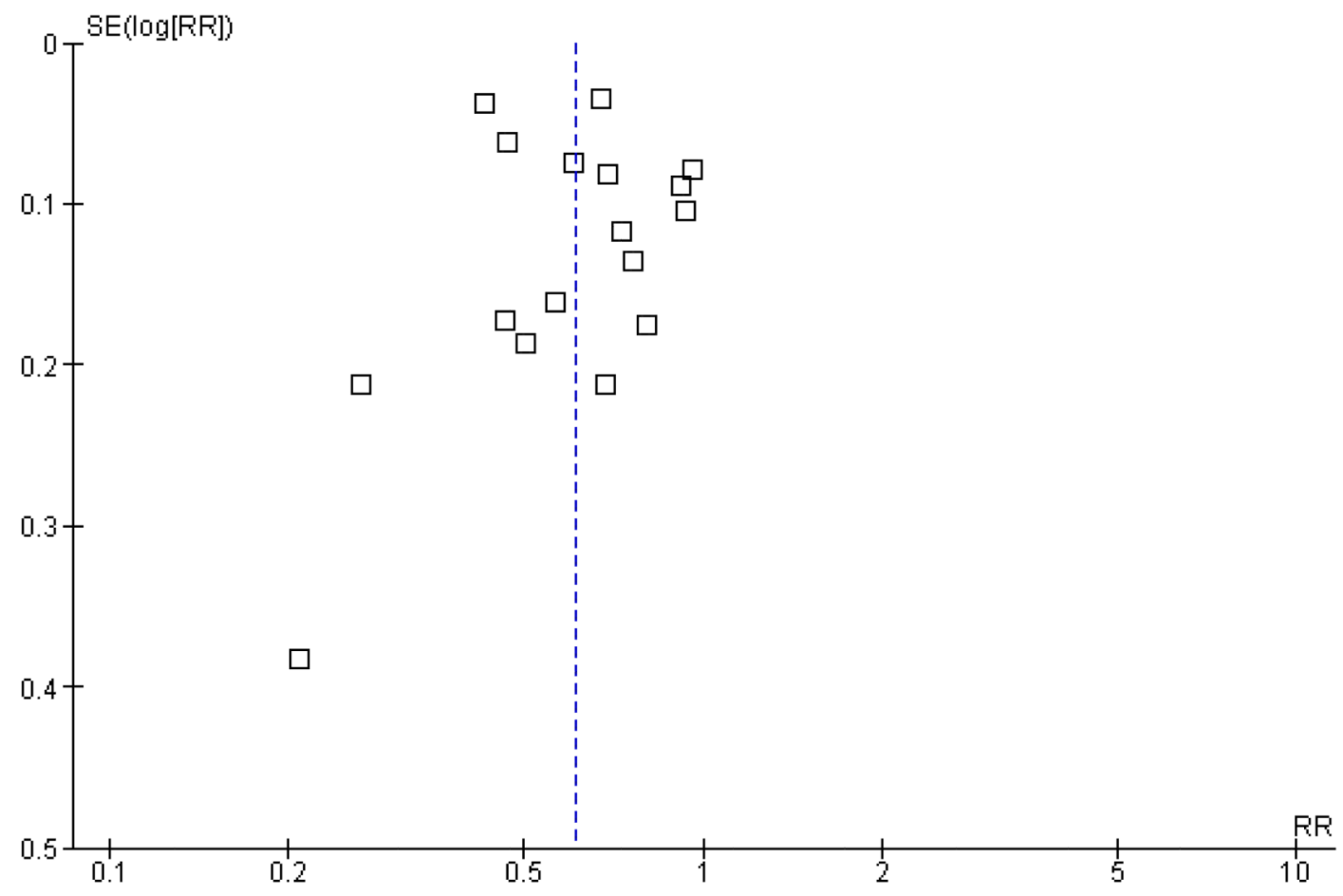

Figure 1. Funnel plot of comparison 1.1 Patients exposed to blood transfusion (all studies) 


\begin{tabular}{|c|c|c|c|c|c|c|}
\hline & 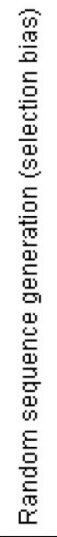 & 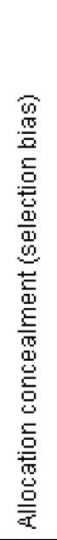 & 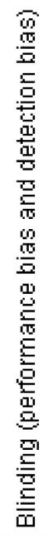 & 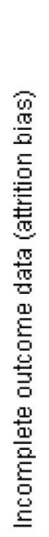 & 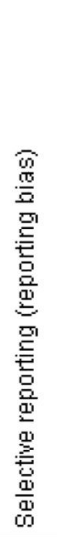 & 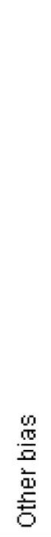 \\
\hline Blair 1986 & $?$ & $?$ & $?$ & $\odot$ & $?$ & + \\
\hline Bracey 1999 & - & 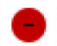 & $?$ & $\odot$ & $?$ & + \\
\hline Bush 1997 & $?$ & $?$ & $?$ & $\odot$ & $?$ & $\odot$ \\
\hline Carson 1998 & + & + & $?$ & $\oplus$ & 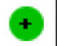 & $\odot$ \\
\hline Carson 2011 & + & $\oplus$ & $?$ & $\oplus$ & $\oplus$ & + \\
\hline Colomo 2008 & $?$ & $?$ & $?$ & $?$ & $?$ & + \\
\hline Fortune 1987 & $?$ & $?$ & $?$ & + & $?$ & + \\
\hline Foss 2009 & + & $?$ & $?$ & $\oplus$ & $?$ & + \\
\hline Grover 2005 & + & $?$ & $?$ & $?$ & $?$ & + \\
\hline Hajjar 2010 & $\oplus$ & $?$ & $?$ & $\oplus$ & $?$ & + \\
\hline Hebert 1995 & $?$ & $?$ & $?$ & + & + & + \\
\hline Hebert 1999 & + & $?$ & $?$ & + & + & + \\
\hline Johnson 1992 & $?$ & 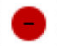 & $?$ & $?$ & $?$ & $\oplus$ \\
\hline Lacroix 2007 & $?$ & + & $?$ & + & + & + \\
\hline Lotke 1999 & + & $?$ & $?$ & $?$ & $?$ & + \\
\hline So-Osman 2010 & $?$ & $?$ & $?$ & $?$ & ? & + \\
\hline Topley 1956 & $?$ & $?$ & $?$ & + & ? & + \\
\hline Webert 2008 & + & + & $?$ & + & ? & + \\
\hline Zygun 2009 & + & $?$ & $?$ & $\oplus$ & $?$ & + \\
\hline
\end{tabular}

Figure 2. 'Risk of bias' summary: review authors' judgements about each methodological quality item for each included study 


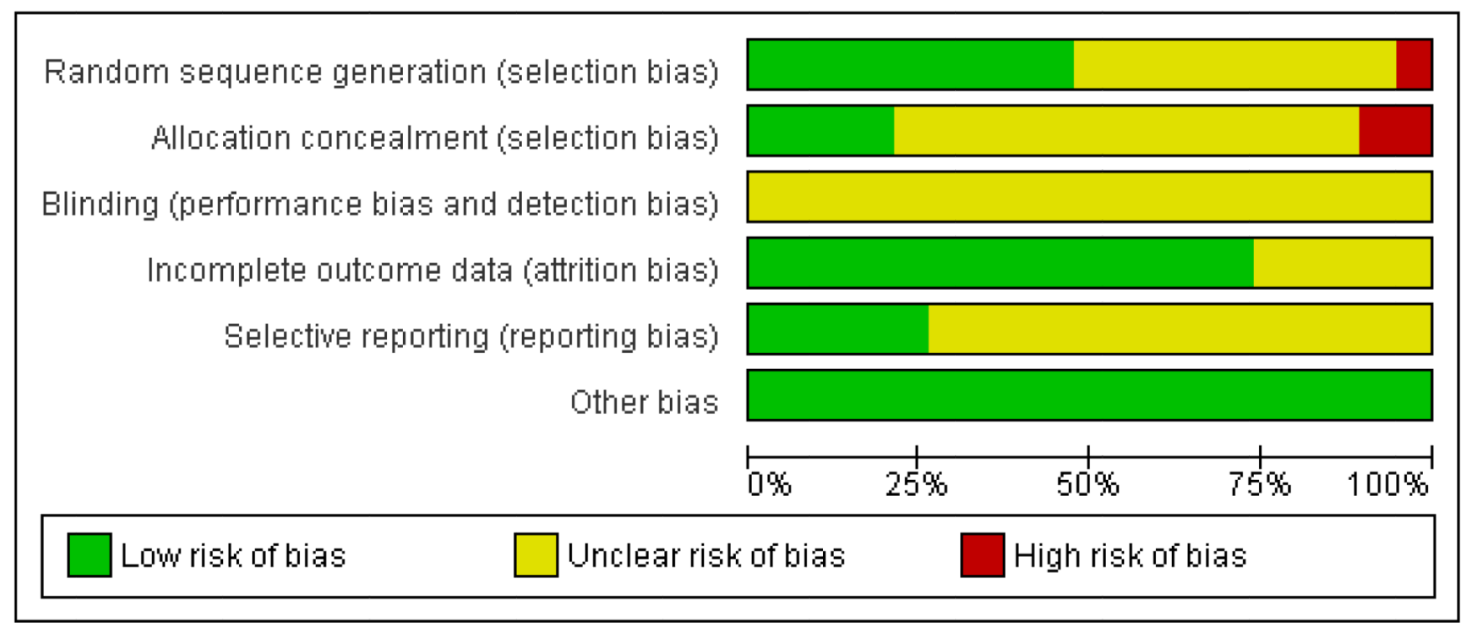

Figure 3. 'Risk of bias' graph: review authors' judgements about each risk of bias item presented as percentages across all included studies. Nineteen studies are included in this review 